\title{
ENSAIOS E PRÁTICAS EM MUSEOLOGIA
}

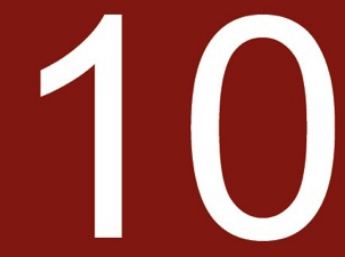

Paula Menino Homem | Bárbara Andrez Germana Soares | Leonor Amaral

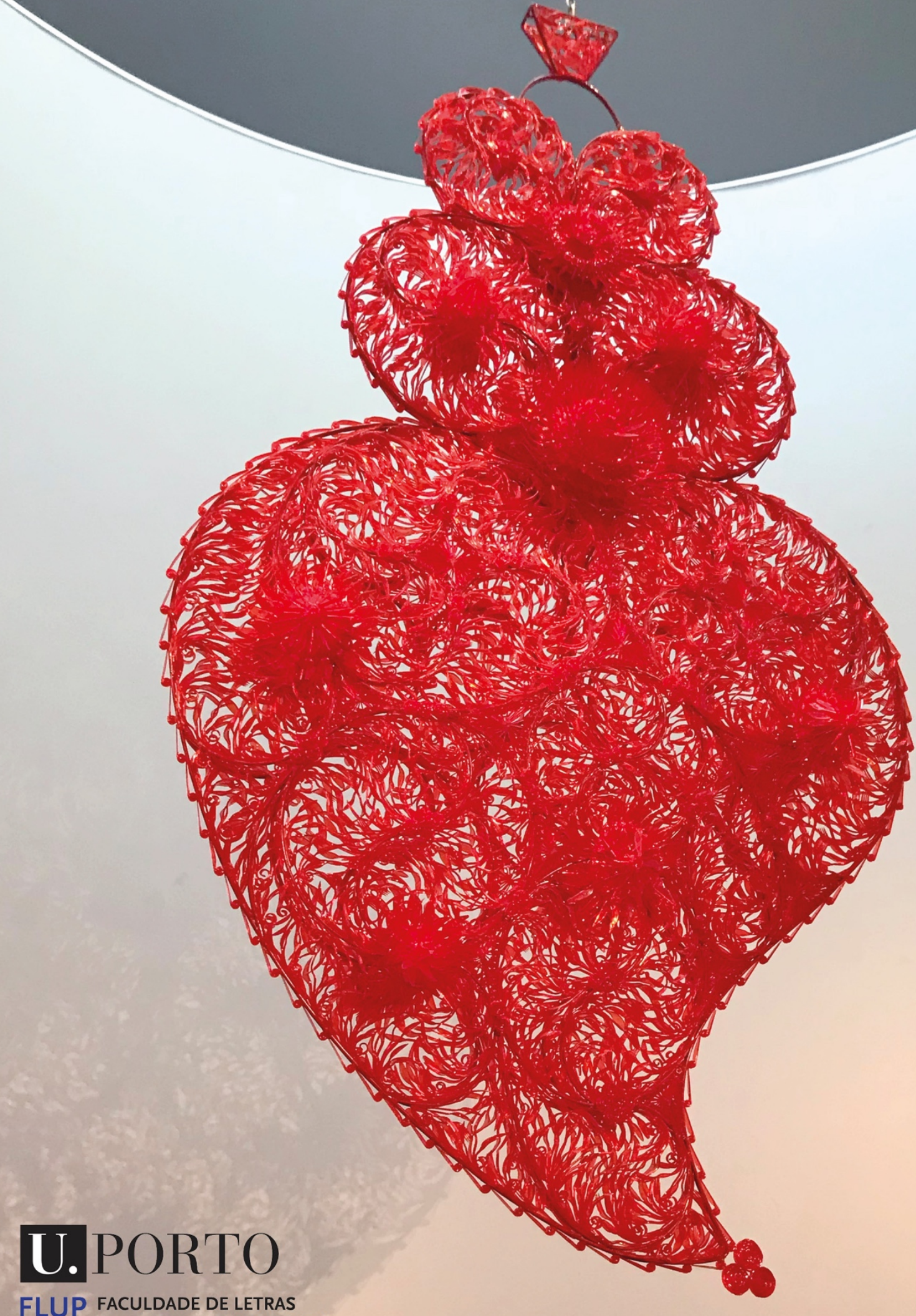

FLUP FACULDADE DE LETRAS

UNIVERSIDADE DO PORTO 


\section{ENSAIOS E PRÁTICAS EM MUSEOLOGIA volume 10}


TÍTULO

ENSAIOS E PRÁTICAS EM MUSEOLOGIA

\title{
VOLUME
}

10

\section{COMISSÃO EDITORIAL}

Paula Menino Homem

Bárbara Andrez

Germana Soares

Leonor Amaral

\section{REVISÃO CIENTÍFICA}

Alice Duarte

Alice Semedo

Elisa Noronha Nascimento

Maria Manuela Pinto

Patrícia Remelgado

Paula Menino Homem

Rui Centeno

\section{EDIÇÃO}

Universidade do Porto / Faculdade de Letras (FLUP) /

Departamento de Ciências e Técnicas do Património (DCTP) / Mestrado em Museologia (MMUS)

\section{LOCAL DE EDIÇÃO}

\author{
Porto
}

ANO

2021

\section{ISBN}

978-989-9082-06-9

\section{$\mathrm{DOI}$}

https://doi.org./10.21747/978-989-9082-06-9/102021

\section{FOTOGRAFIA DA CAPA}

Germana Soares

Obra "Coração Independente Vermelho" - Joana Vasconcelos

\section{DESIGN GRÁFICO}

Germana Soares

\section{ALOJADO EM}

Biblioteca Digital da FLUP 
Sumário 


\section{Leonor Amaral}

Museus, responsabilidade social e a pandemia da COVID-19

Isabel Silva

Em torno da musealização do património cultural religioso

\section{Juliana Bittencourt}

Centro Interpretativo do FEUPmuseu: um espaço de encontro

\section{Vanessa Sampaio Neves}

Museu Almeida Moreira: públicos e motivações de visita

\section{Louise Palma}

Avaliação diagnóstica de serviços educativos: alguns resultados do caso da

Rede de Museus de Vila Nova de Famalicão

Sofia Navalho

Casa-Museu Soledade Malvar: edifício, coleção e inventário

Marta Fontoura Miranda

Património Escolar do Ensino Primário (PEEP) e coleções nos museus do norte de Portugal 108

Bárbara Andrez

Infocomunicação em museus: uma reflexão à luz do paradigma da complexidade de Edgar Morin

Mariana Espel de Oliveira

Museu empreendedor: Usina de Eureka, um modelo de negócio para museus

\section{Cláudia Garradas}

O Malta Study Center @ Hill Museum \& Manuscript Library: percurso e convergências 
$\S$ 
Apresentação 


\section{Apresentação}

Mais um ano volvido e eis o décimo volume da série Ensaios e Práticas em Museologia (E\&PM)!

Um ano marcado, ainda, por um contexto de mudança e de incerteza a ela associada. No que diz respeito ao Mestrado em Museologia (MMUS) da Faculdade de Letras da Universidade do Porto (FLUP), assinala-se a jubilação do último dos responsáveis pela criação da área da Museologia na FLUP, em 1992, que permanecia no ativo; o Prof. Doutor Rui Centeno. Fica aqui a nossa humilde, mas sentida, homenagem à personalidade e um profundo agradecimento ao contributo. Desde o dia 13 de agosto de 2021, o MMUS deixou de contar com a sua colaboração ao nível do corpo docente, mas tem a honra de beneficiar da sua investigação ativa e do acompanhamento científico que continuará a fazer aos estudantes.

Assinala-se, também, a preparação de nova fase de avaliação externa e independente ao MMUS, por parte da Agência de Avaliação e Acreditação do Ensino Superior (A3ES), agendada para janeiro de 2022. A partir dela, perspetivam-se ajustes e mudanças no ciclo de estudos, para melhor fazer face às novas exigências, ao nível de educação e formação, e necessidades, ao nível dos profissionais dos museus e dos que aspiram a sê-lo. E são já tantos os que passaram pelos diferentes formatos de ciclos de estudo em Museologia da FLUP...

O espírito da E\&PM reflete o espírito inclusivo e agregador do MMUS, envolvendo alumni em diferentes contextos de colaboração: da supervisão dos mais novos e acompanhamento dos trabalhos desenvolvidos, à divulgação de tais trabalhos e ao processo editorial inerente à sua publicação. Vários já envolvidos no desenvolvimento de outros ciclos de estudo, de doutoramento, na área da Museologia ou em áreas de confluência, com aplicação e benefício para o setor dos museus. Não obstante as adversidades suscitadas pela pandemia de COVID-19, o esforço de superação foi 
relevante, tal como o contributo dos estudantes e profissionais para as instituições museológica.

Assim, como sempre e é devido, agradecendo aos seus colaboradores, a Comissão Editorial deste volume partilha experiências e reflexões que incluem uma diversidade temática e em que:

Leonor Amaral sublinha a importância da responsabilidade social dos museus e considera o modo como a pandemia de COVID-19 interferiu na sua relação com os públicos. Reflete quanto ao seu lugar na sociedade e quanto aos seus modelos de gestão, nomeadamente no que diz respeito à comunicação e ao envolvimento social;

A partir da sua experiência de trabalho desenvolvido no Museu de Arte Sacra da Capela da Lapa, em Vila Nova de Famalicão, Isabel Silva desenvolve a questão da musealização do património cultural religioso. Tece considerações relativamente às opções tradicionalmente adotadas e ao modo como interferem na interpretação e fruição desse património e apresenta uma proposta para o contexto;

Os interesses de Juliana Bittencourt orientam-se para os museus universitários. Constata a pluralidade dos seus modelos estruturais, em termos de características e dinâmicas, exemplificado com alguns espaços museológicos da Universidade do Porto. A partir deste amplo contexto, foca-se no Museu da Faculdade de Engenharia da Universidade do Porto (FEUPmuseu), utilizando-o como ponto de partida para uma discussão relativa ao museu universitário como interseção, área de encontro, entre dois polos distintos, museus e centros interpretativos;

Interessada pelos públicos dos museus e pelas suas motivações para os visitarem, Vanessa Sampaio Neves, partilha o estudo que desenvolveu no Museu Almeida Moreia, em Viseu, como contributo para a sua caracterização e para a tomada de decisão fundamentada, no que respeita à definição de estratégias a adotar; 
A Rede de Museus de Vila Nova de Famalicão beneficiou de uma avaliação diagnóstica relativamente aos seus serviços educativos, desenvolvida por Louise Palma, cujos resultados demonstram a relevância do método para a definição de melhorias a implementar;

Sofia Navalho partilha o trabalho que desenvolveu também em Vila Nova de Famalicão, mais concretamente na Casa-Museu Soledade Malvar. Centra-se no estudo da história da instituição e de uma pintura da sua coleção, realçando o contributo para a melhoria da qualidade de informação relativa ao inventário da coleção de pintura;

Tendo o Património Escolar do Ensino Primário e as coleções nos museus do norte de Portugal como interesse de investigação para sua preservação, Marta Fontoura Miranda partilha o trabalho desenvolvido no âmbito do projeto REduF, contexto que Ihe proporcionou uma perspetiva de abordagem interdisciplinar;

Bárbara Andrez, considerando o paradigma da complexidade desenvolvido por Edgar Morin, reflete sobre alguns problemas sistémicos, no que diz respeito aos processos de informação e de comunicação nas instituições museológicas, no sentido de identificar relações e potenciar eixos de ação;

Interessada em fomentar e potenciar o espírito empreendedor dos museus, Mariana Espel de Oliveira, apresenta o desenvolvimento de um modelo de negócio, visando a criação de uma interface de estímulo criativo e de inovação, como contributo para o esenvolvimento local sustentável;

Cláudia Garradas colabora, desde 2016, com o Malta Study Center, que integra o Hill Museum and Manuscript Library. Apresenta a instituição, focando-se na sua missão de preservação e divulgação da herança cultural da Ordem de Malta e no desenvolvimento de projetos de digitalização, inventariação e catalogação de coleções públicas e privadas.

Paula Menino Homem, Bárbara Andrez, Germana Soares, Leonor Amaral 


\section{Leonor Amaral}

leonordamaral@gmail.com

Museus, responsabilidade social e a pandemia da COVID-19. 
Resumo

Momento ímpar na História Contemporânea, a pandemia da COVID-19 veio reforçar a pertinência da reflexão em torno da responsabilidade social dos museus. As sucessivas restrições e limitações aplicadas em contexto de crise pandémica vieram transformar a forma como os museus operaram durante o último ano e a sua relação com os públicos. Neste contexto, o pensamento em torno da comunicação em museus e do papel dos modelos de gestão no envolvimento social do museu ganha novos contornos.

Este ensaio insere-se numa linha de pensamento que tem vindo a ser desenvolvida desde o desenvolvimento da dissertação de Mestrado em Museologia e, agora e mais aprofundadamente, sob o mote do projeto de Doutoramento em Estudos do Património - Especialização em Museologia "Encontrar o Museu". Aqui se encontram algumas bases conceptuais que procuram refletir sobre $o$ lugar do museu junto da sociedade e enquadrar o acontecimento da pandemia na memória do pensamento museológico contemporâneo. Este desafiante exercício procura perspetivar expressões futuras de envolvimento sociocultural em museus.

Palavras-chave: Museus; Museologia; Pandemia da COVID-19; Digital; Responsabilidade Social

\section{Nota biográfica}

Leonor Amaral é formada em História da Arte e mestre em Museologia pela Faculdade de Letras da Universidade do Porto, com a dissertação «Os impactos da cultura digital na comunicação em museus. Um olhar sobre a comunicação digital dos Museus Nacionais em Portugal». Desde 2020, desenvolve trabalho de investigação enquanto doutoranda na unidade I\&D CITCEM-FLUP, Centro de Investigação Transdisciplinar Cultura, Espaço e Memória.

\section{Abstract}

The COVID-19 pandemic reinforced the pertinence of reflection on the social responsibility of museums. The successive restrictions and limitations applied in the context of the pandemic crisis have transformed the way in which museums operated during the last year and their relationship with the public. In this context, thinking about communication in museums and the role of management models in the museum's social involvement takes on new contours.

This essay is part of a line of thought that has been developed since the development of the master's thesis in Museology and, now and in greater depth, under the motto of the $\mathrm{PhD}$ project in Heritage Studies - Specialization in Museology "Finding the Museum. Here are some conceptual bases that seek to reflect on the museum's place in society and frame the event of the pandemic in the memory of contemporary museological thinking. This challenging exercise seeks to envision future expressions of sociocultural involvement in museums.

Keywords: Museums; Museology; COVID-19

Pandemic; Digital; Social Responsibility

\section{Biographical note}

Leonor Amaral has a degree in Art History and a master's degree in Museology from the Faculty of Arts and Humanities of the University of Porto, with the dissertation (in Portuguese) «The impacts of digital culture on communication in museums. A look at the digital communication of National Museums in Portugal». Since 2020, she has been carrying out research work as a doctoral student at the I\&D Research Unit CITCEM-FLUP, Transdisciplinary Research Centre «Culture, Space and Memory». 


\section{Introdução}

Quando, em março de 2020, o universo dos museus foi confrontado com a crise pandémica da COVID-19 e com o cenário do seu encerramento de portas por tempo indeterminado, conheceu, em simultâneo, um novo período/ciclo de mudança. O ano em questão ficou marcado por uma transição em massa dos museus para a esfera online e pela sua dependência exclusiva da dimensão digital para darem continuidade ao cumprimento das suas missões.

A partir do digital, passou a ser possível aceder a um número muito superior de conteúdos disponibilizados por instituições museológicas espalhadas por todo o mundo. Ainda assim, neste processo, evidenciaram-se assimetrias ao nível do investimento e conhecimento em museus, face às tecnologias de informação e comunicação e às plataformas digitais. Esta não foi, todavia, uma surpresa. Um estudo desenvolvido no âmbito do Projeto Mu.SA - Museum Sector Alliance (Silvaggi \& Pesce, 2017) já havia confirmado que, nas competências digitais necessárias ao profissional do museu, se encontram os alicerces para a proficiente utilização das tecnologias digitais em museus. Nesse contexto, o consórcio alertava para uma escassez generalizada de investimento em equipamento e formação das equipas ao nível das competências digitais. As instituições em que este tipo de investimento se assumiu escasso ou inexistente viram a sua performance ser, inevitavelmente, limitada. Não obstante, se se considerar o objetivo nuclear desta transição alargada, constatou-se que, na generalidade dos casos e no que diz respeito à manutenção do contacto com o público, tal objetivo se cumpriu, embora, sublinhe-se, de forma umas vezes mais eficiente do que outras.

Ao abrirem as portas a uma intensificação do uso das tecnologias e plataformas digitais, os museus não só possibilitaram a concretização da sua programação, como encontraram novos alcances e exploraram dinâmicas de experiência, trabalho e interação social inovadoras. 
Durante 2020, organizações como a United Nations Educational, Scientific and Cultural Organization (UNESCO), o Internacional Council of Museums (ICOM), Ibermuseus, ICOM Portugal e outras, desenvolveram estudos assentes em amostras de escala internacional e nacional, que visaram propor uma avaliação dos impactos da pandemia em museus. Verificou-se que a generalidade seguiu uma tendência de enquadramento analítico quantitativo, focado, sobretudo, no contexto interno e voltado, em primeiro lugar, para os impactos com reflexos financeiros.

Esta tendência já havia merecido análise em Rodley, Stein e Cairns (2015), que denotam uma persistência pela busca do valor dos museus e seu impacto económico. Não desconsiderando a natural importância do conhecimento desses dados, os autores assumem que a contribuição financeira da cultura para as cidades não reflete a razão pela qual as instituições culturais representam um benefício para as suas comunidades, acrescentando que a posição dos museus dentro do espectro de oferta cultural deveria ser, preferencialmente, assegurada a partir do seu valor social. A pandemia demonstrou a pertinência desta perspetiva e introduziu nos diversos setores, instituições e sociedade, múltiplos desafios de natureza económica, sanitária e de bem-estar onde, por sua vez, a noção de responsabilidade social saiu reforçada e o papel dos museus se demonstrou determinante para a resiliência da sociedade.

Considera-se aqui que possa existir uma possibilidade de encontrar um sentido mais profundo sobre o papel dos museus na sociedade e o impacto do digital sobre essa relação, através da exploração de conhecimentos para lá dos seus termos de aplicabilidade e envolvimento. Por este ser um engenho que é social antes de ser técnico (Teixeira, 2020), o seu pensamento implica conhecer-se o tipo de uso, mas acima de tudo, as implicações que esse uso exerce sobre o público recetor/participante. 


\section{Situar}

Os exercícios de reflexão sobre o conceito de cultura revelam-se basilares para o pensamento sobre dinâmicas socioculturais. Appadurai (1996), ao propor a sua definição a partir de uma dimensão de fenómenos revelada pela diferença situada e concretizada, traz, à luz da globalização, o conceito de cultura que traspassa uma ideia de propriedade de indivíduos e grupos, para se constituir enquanto um instrumento heurístico ao nosso alcance para falarmos de diferença:

A característica mais valiosa do conceito de cultura é o conceito de diferença, uma propriedade de certas coisas mais contrastiva do que substantiva (p. 26).

A referência a «culturas» ao invés de «cultura», proposta por Mason (2006), segue a mesma linha de ideias que posiciona a diferença no cerne do discurso cultural contemporâneo: A cultura enquanto dimensão penetrante do discurso humano, que explora a diferença para gerar diversas conceções da identidade de grupo e que, ao mesmo tempo, comporta o peso de um processo histórico que também é desigual e até mesmo localizador. Neste contexto, os museus surgem como objeto de interesse e estudo, reconhecendo-Ihes a sua capacidade de materializar valores e de apresentar processos de formulação de significados.

Este não é, contudo, um pensamento que possa ser mantido à margem dos fenómenos que vieram situar o digital no centro da nossa ação enquanto seres sociais (Teixeira, 2020). O surgimento da denominada cultura digital representa o efeito da disseminação da tecnologia, hoje inerente aos processos culturais da sociedade contemporânea. Alguns autores têm-se debruçado sobre este tema. Gere (2008) encontra na cultura digital um fenómeno social cujo estudo sugere uma abordagem holística face aos nossos hábitos, apontando o individuo como motor social que pela força da necessidade e utilidade, seleciona os elementos técnicos. Neste sentido, o proposto é que, no processo de apropriação cultural na era do digital, a tónica se situe sobre o indivíduo e que o processo resulta de um engenho que, antes de ser técnico, é 
social. Miller (2011) explora estes conceitos em Understanding Digital Culture, focando-se na integração e no uso sociocultural massivo dos instrumentos e tecnologias de informação e comunicação wireless, e no modo como as nossas ações e atitudes são moldadas por esta realidade que abandona a ideia de separação entre a esfera online e o mundo offline. Neste contexto, muitos são os autores que recorrem a Walter Benjamin e à sua publicação de 1936, The Work of Art in the Age of Mechanical Reproduction (Benjamin, 2008), servindo-se da sua perspetiva para abordar as tensões autenticidade-experiência, tangível-intangível e refletir sobre as mais-valias consequentes das transformações tecnológicas, como o ambiente criativo, colaborativo e de cocriação que se fez germinar. A esta, Cruz (2016) denomina-a de uma "cultura da participação". Miller (2011), por sua vez, questiona-se se, nesta nova realidade, poderá ser a cultura passiva face à tecnologia. Citando Giddens, Lopes (2016) classifica como inoperante a divisão similar que Giddens exerce sobre o espaço que se torna fantasmagórico porque é deslocado dos cenários físicos de interação face a face. Em Lopes (2016) encontramos o abandono da dicotomia real/virtual, e a promoção de um entendimento sobre a nossa existência enquanto esta sendo multifacetada e cruzada de um real-real e de um real-virtual.

A questão sobre a verdadeira definição de «cultura» nos nossos dias, e a dimensão que a «cultura digital» nela ocupa, permanece, ainda assim, enevoada. Não obstante, a capacidade metamórfica inerente à cultura digital abre a possibilidade de esta se materializar sobre múltiplos conceitos, paradigmas, abordagens, cuja contemplação se manterá, inevitavelmente, condicionada a transformações digitais, características de uma cultura marcada por interações de nova ordem, nova intensidade, novos hábitos de consumo e, como salientado em Appadurai (1996), por um abandono do sentido de lugar.

O mundo globalizado, as dinâmicas socioculturais de nova ordem e intensidade, a revolução tecnológica e o surgimento da denominada cultura digital, são fenómenos que influenciaram de forma direta e indireta o modo dos museus se posicionarem perante a sociedade. Um olhar sobre os seus desdobramentos na museologia será 
feito através de três eixos temáticos: A Nova Museologia; O conhecimento como necessidade cultural; Os museus na era digital.

\section{Desdobramentos}

\subsection{Nova Museologia}

Se é verdade que a função primordial do museu se mantém a salvaguarda do património, também é verdade que, nas últimas décadas, os museus se têm confrontado com desafios na ordem da sua organização, posicionamento perante a sociedade, narrativas construídas e na maneira de se darem a conhecer aos públicos (Oleiro, 2005). A transição do paradigma do museu centrado em si mesmo para o museu enquanto entidade comunicadora, interventiva, apostada na divulgação, capaz de uma programação com capacidade para alcançar novos públicos idealmente de forma contínua, que nos traz Oleiro (2005), encontra a sua génese num movimento de larga abrangência teórica e metodológica, cujas mudanças geradas se assumem centrais para a renovação da instituição museológica no final do século XX (Duarte, 2013) denominado de Nova Museologia. Para esta autora, as linhas de renovação que produziram nos anos 1980 as vertentes francófona e anglo-saxónica da designada Nova Museologia, conduziram aos princípios transformadores de renovação: o projeto e o ideal político de democratização cultural com a ajuda do museu e a eleição do museu e suas práticas enquanto campos de reflexão teórica e epistemológica. Portanto, considera que, de forma clara, sob a Nova Museologia, todas as atividades do museu se tornaram objeto de reflexão teórica e política. Atendendo às leis de difusão cultural, estas passaram a operar sobre um espaço globalizado. Por tal, numa sociedade marcadamente heterogénea, com diferentes interesses, motivações, curiosidades e modos de percecionar, a relação entre a instituição passou a estabelecer-se a partir da natureza e qualidade da mensagem, do contexto e da estrutura do público, e do reconhecimento sobre o valor da diferença. 
Nos anos sessenta, Boudieu e Darbel (2003) ao proporem a ideia de que "são apenas excluídos os que se excluem" (p. 69) e de que existe uma desigualdade natural naquilo a que chamam "necessidades culturais" (p. 69), constroem uma afirmação controversa. Não obstante, este exemplo permite-nos entender que os autores estão, por um lado, a confirmar um alargamento do espectro social que tinha o acesso ao museu e, por outro, a constatar que a fruição cultural se tornava uma opção própria. Ao pressuporem que estes processos se desenrolam a partir da lógica de causa-efeito, os autores posicionam a aspiração cultural consoante a prática cultural que, se satisfeita, aumenta e, em falta, se demarca pela ausência de sentimento de privação. Nesta perspetiva, os museus passavam a encontrar um cenário de motivação e de responsabilidade no tocante à fomentação de um sentimento de aspiração cultural em comunidades que, como tem vindo a ser denotado, se encontra ligado à dimensão que marca a sociedade contemporânea; a diferença.

\section{2. $O$ conhecimento como necessidade cultural}

O reconhecimento da educação enquanto força motriz de necessidade cultural será sentida pelos museus. Falk e Dierking (2000) destacam a aprendizagem como o cerne desta apreciação crescente sobre as instituições, referindo-se a ela enquanto o bem primário que os visitantes recolhem da sua experiência no museu. Ainda assim, são consideradas, dentro e fora dos museus, questões que colocam sob análise a possibilidade de alguma aprendizagem ocorrer nos museus e em que termos tal pode acontecer.

Falk et al. (2006) consideram que as sociedades ocidentais que, no século passado, transitaram de uma economia baseada na indústria para uma economia assente na informação/conhecimento, assistiram, simultaneamente, à transformação do conhecimento e da informação nos maiores produtos económicos do mercado atual, o que levou a mudanças consideráveis na forma como os cidadãos conduzem as suas 
vidas. Desenvolve-se, assim, a ideia de que a aprendizagem passa a ser matéria central para a sociedade e desperta-se uma consciência generalizada sobre as limitações do sistema de educação formal tradicional, o que levará ao reconhecimento da importância da educação em contexto não formal.

A aprendizagem de livre escolha converte-se, gradualmente, na estratégia de aprendizagem preferida no século XXI. À medida que a sociedade se torna mais submersa em informação, dizem-nos Falk et al. (2006), cada cidadão encontra a necessidade de aprender, de forma qualitativa e quantitativa, estratégias apuradas para lidar com essa informação. Os mesmos autores concluem que cada cidadão passará a maior parte da sua vida, cerca de $97 \%$, fora do sistema tradicional de aprendizagem, sendo que, a aprendizagem de livre escolha, como alternativa, atribui aos museus um papel-chave enquanto seus facilitadores e documentadores.

Associado a estas questões surge o fator de responsabilidade social dos museus. À luz da pandemia, parece ter saído reforçada a necessidade de encontrar a responsabilidade social dos museus, que se relaciona diretamente com a sua oferta e evidências da sua concretização. Atenta-se muitas vezes ao número de visitantes para medir estes fatores. Não obstante, a realidade vivida em período de crise pandémica realçou as limitações sobre esse tipo de abordagem. Como se afirma em HooperGreenhill (2006), as técnicas de medição, contabilização e mapeamento, associadas ao estudo demográfico dos visitantes providenciaram certos tipos de informação que, ainda assim, não são capazes de demonstrar o valor da experiência para o visitante.

Na década de 1980, no Reino Unido, foram introduzidos os estudos de visitantes ligados à investigação do mercado, incluindo o estudo nos "não públicos”/“não visitantes" (Hooper-Greenhill, 2006, p. 365) e despertados interesses sobre a exploração das perceções e sentimentos quanto aos museus. Para aqueles que trabalhavam nos museus, tornou-se clara a essencialidade da exploração das atitudes e valores dos visitantes e não visitantes, dentro de toda a subjetividade que tal pudesse envolver. Na década de 1990 emergiram novas abordagens que desafiavam 
outras prévias - observações de comportamento, questionários estruturados e entrevistas - encaradas enquanto independentes da teoria, mas que eram, de facto, sustentadas em teorias desatualizadas das abordagens dos estudos sociais baseados na psicologia empirista e educacional (behaviorista) (Hooper-Greenhill, 2006). A questão central dos investigadores passou a ser construção de significados e os métodos que providenciassem a sua descrição e análise qualitativa. Hooper-Greenhill (2006) incita-nos à reflexão questionando se estes processos de criação de significado são contingentes, variáveis e fluidos, e como podem ser estudados. Ao que esta reflexão acrescenta, em período de crise pandémica, numa sociedade forçada ao confinamento, inserida numa economia assente sobre o conhecimento, em que o museu surge enquanto espaço inclusivo, de participação, interação e aprendizagem e em que os dados meramente quantitativos não refletem o seu impacto, como poderá ser medida a qualidade da experiência e a perceção da sociedade sobre o museu atualmente?

\subsection{Os museus na era digital}

O fenómeno da internet exerce um impacto significativo nos nossos hábitos e comportamentos, tendo transformado o modo como operamos, aprendemos, geramos conhecimento e participamos na vida pública. Ainda que nem toda a sociedade global seja abrangida pela tecnologia interconectada, a globalidade continua a ser afetada pelos processos desenvolvidos nesta rede de trabalho (Baker, 2013). Em resultado disso, assistimos à multiplicação dos discursos dominantes sobre a aceleração sem precedentes do fenómeno digital, que conta, por um lado, com os céticos que realçam a disseminação de uma iliteracia digital e, por outro, com os otimistas que apregoam as imensas possibilidades do novo conhecimento e das novas tecnologias (Lopes, 2016). Situemo-nos sobre o meio. 
Na denominada era da informação ou era digital, a utilização das novas tecnologias pelos museus é particularmente diversa. Não admira que Ross Parry (2010) tenha assumido a existência de corpo diaspórico na literatura para caracterizar a que tem sido desenvolvida neste âmbito. Por isso, o seu estudo implica um enquadramento, sob pena de se tornar vago, incerto, ou simplesmente demasiado ambicioso. As várias possibilidades de aplicabilidade vão desde a análise e tratamento de dados, ao inventário, à catalogação, às tecnologias de representação em realidade aumentada e realidade virtual, à comunicação digital, e em diante.

Neste enfoque, debruçamo-nos sobre a comunicação digital enquanto meio de divulgação do património e, sobretudo, de interação com a sociedade. O termo sociedade torna-se, doravante, meramente convencional. Neste universo, o recetor é simultaneamente participante, encontrando-se numa posição de proximidade. Ao operarem neste contexto, os museus conheceram âmbitos específicos de abordagem e interação, assentes em métodos e normas orgânicas definidas a partir de tendências. Aqui, o conceito de comunicação digital encontra-se intimamente ligado à resposta a necessidades, interesses, curiosidades de segmentos específicos da sociedade. A definição destes segmentos acompanha a tendência para a valorização da diferença, cada vez mais unificadora do que dispersante. As comunidades digitais, dominantes face ao mercado da oferta e da procura, são compostas por utilizadores, produtores e/ou consumidores e definem-se a partir do seus gostos e interesses, representando o encontro e coalescência em torno de experiências, motivações e atitudes partilhadas, marcando, assim, um abandono da organização tradicional da sociedade baseada em dados demográficos.

Portanto, a comunicação digital passou a ser uma, senão a, estratégia de comunicação externa mais importante dos museus. Para Teixeira (2020), a crença inicial no processo de digitalização de coleções, enquanto garantia de uma "pegada digital" (p. 47) do museu, rapidamente caiu por terra, dando lugar a um entendimento que o considera o primeiro passo de um caminho a ser percorrido. Neste campo de ação museológica, 
fortemente apoiado numa lógica de equidade participativa, persistirá a questão: Para quem produz o museu?

Em sintonia com Wong (2012), ao enfrentarem questões sobre a sua definição e relevância, os museus encontraram no digital, e sobretudo nas redes sociais, um espaço em crescendo que não só oferece novos canais de expansão e diversificação do seu alcance, como promove a ação de proximidade, menos intimidante e mais regular com os públicos. A autora conclui que, ao assumirem que, através da utilização destas plataformas, os museus encontram um potencial de democratização das suas práticas, prontamente assistimos ao surgimento de novas metodologias e experimentações institucionais que vieram aumentar a sua acessibilidade, abertura, transparência e a capacidade de resposta, ao mesmo tempo que se abre espaço aos públicos para se manifestarem e participarem em sinergias de envolvimento cultural, numa lógica em linha com o conceito de autoridade partilhada e construção colaborativa de conhecimento.

Este não é, ainda assim, um campo neutro. Para Wong (2012), apesar de representarem uma aproximação aos valores democráticos, estas plataformas encontram-se ainda bastante longe de um combate às desigualdades sociais. Tal reforça uma necessidade elementar para a ação dos museus em redes sociais, de implementação de critérios face ao tipo de uso e de projeção de retorno, no sentido de se encontrarem caminhos metodológicos sustentáveis que representem uma contribuição positiva e que equilibrem os objetivos práticos do museu e as necessidades culturais dos seus públicos. A sua avaliação, central para o pensamento e planeamento dos museus, revela-se um desafio. Por exemplo, como pode ser medido o impacto do uso das redes sociais por parte dos museus na criação de bem-estar? De que forma a atividade de determinado museu nas redes sociais promove valores de equidade, inclusão, justiça ou sustentabilidade? E com que efeitos práticos, de que forma o acesso aos conteúdos digitais dos museus nestas plataformas motiva a visita? 


\section{0 acontecimento da pandemia da COVID-19}

Reconhecendo que algumas destas práticas e conhecimentos já faziam parte dos museus antes da pandemia da COVID-19, para muitas instituições, o confinamento a ela inerente tornou-se um momento de viragem e de transição. A massificação do uso das ferramentas digitais foi sentida por todas as equipas de museus, independentemente da sua natureza, coleções, equipas e do seu orçamento.

Volvidos a uma aparente normalidade e prevendo um gradual retorno ao espectro natural da ação do museu, equilibrado entre as esferas física e virtual, será tempo de refletir sobre a adequação e sustentabilidade das práticas exploradas por estas instituições durante a pandemia, no seu sentido de aplicabilidade dentro do "novo normal" que acompanhará o futuro dos museus.

Teixeira (2020) identifica alguns pressupostos como de partida: reconhece-se a sua amplitude e capacidade de integração do digital na mais ínfima atividade praticada dentro e pelo museu; o objetivo não será o de ter um departamento digital, mas que a instituição saiba tirar o proveito da forma mais eficiente possível desta ferramenta para fazer cumprir a sua missão; não existirá uma fórmula única de encarar esta ferramenta, senão múltiplas; e, por último, não existirá um modelo de aplicação, senão conjuntos de boas práticas e bons exemplos a considerar.

Pensar-se na introdução ou no reforço do digital na estratégia de um museu engloba essencialmente agir a partir do investimento nas infraestruturas e na formação das equipas. Ao impor um tipo de conhecimento e comunicação completamente diferente daquele a que nos habituámos a encontrar nos museus, mais interativa e interpessoal, o digital faz com que esperemos dos profissionais de museus a flexibilidade de aprendizagem de novas competências que respondam às novas exigências que enfrentam, bem como um reforço por parte da tutela sobre o investimento que é feito nesta capacitação. A crise pandémica veio não só tornar urgente esta transição, como justificar a necessidade no seu investimento. A falta de acesso aos seus espaços dos 
museus terá intensificado a atividade online e em particular a comunicação digital dos museus, tendo-se observado o desenvolvimento de estratégias de ação especificamente assentes sobre este contexto.

Segundo os dados recolhidos pela Network of European Museum Organisations (NEMO) (2020), cerca de 70\% dos museus na Europa aumentaram a sua presença online desde o início do período de confinamento e, após três semanas do encerramento de portas, cerca de $80 \%$ dos museus tinham aumentado a sua atividade online. Cerca de $80 \%$ dos museus reorientaram as suas equipas para acomodar as necessidades correntes e $30 \%$ dos museus mudaram as tarefas dos seus profissionais a fim de criar uma equipa orientada para a atividade digital. A percentagem de museus que aumentou o seu orçamento direcionado para as atividades digitais foi, ainda assim, menor do que se esperava, pois apenas $16 \%$ dos museus aumentaram o seu investimento no digital. No que concerne ao uso de plataformas digitais, durante o primeiro confinamento os museus utilizaram as redes sociais mais do que nunca. Cerca de $70 \%$ das instituições afirmaram que o museu aumentara a sua atividade nas redes sociais; $80 \%$ usou o Facebook e $20 \%$ usou o Instagram como plataforma principal para o desenvolvimento das suas atividades.

Com o aumento da presença digital dos museus, começaram a surgir estratégias de ação e a UNESCO (2020) sumarizou algumas das abordagens em categorias:

- Uso de recursos digitais já existentes - coleções online, visitas $360^{\circ}$, museus virtuais, publicações online, exposições online;

- Transição para o digital de atividades já planeadas durante o período de confinamento;

- Aumento da atividade nas redes sociais. Os museus aproveitaram o confinamento para desenvolver a sua presença nas plataformas de redes sociais; 
- Criação de atividades em contexto de confinamento, com as instituições a desenvolver conteúdos e projetos especificamente em contexto de confinamento. A título de exemplo, as campanhas \#GettyMuseum Challenge e Between Art and Quarantine do Rijksmuseum.

\section{Considerações finais}

À evolução do pensamento museológico encontra-se subjacente uma constante construção de conhecimento em torno das dinâmicas entre instituição e indivíduo. 0 reconhecimento sobre a centralidade da dimensão social de um museu permite enquadrar e posicionar o serviço às necessidades e interesses das comunidades.

O papel de um museu é o seu reflexo mais único: o seu contexto, a sua organização, a natureza das suas coleções, o ambiente em que se insere, as necessidades e interesses das comunidades com que interage, etc. O reconhecimento deste papel responde à interação entre as noções de desigualdade social e autoridade cultural (Sandell, 2002). O seu potencial e contributo para a mudança e bem-estar social tem suscitado cada vez mais interesse por parte dos estudos socioculturais, por apresentar diversos desafios e possibilidades complementares aos processos utilizados até hoje no relacionamento do museu com a sociedade. Passámos a encontrar, em torno deste debate, valores de inclusão e participação, compreensão e tolerância, partilha e equidade, centrais dentro do universo das redes sociais.

A pandemia, materializada no confinamento dos cidadãos, o encerramento das instituições e numa transição massificada das atividades e experiências em geral para a esfera digital, serviram de incentivo a uma reformulação destas questões. Uma certa perda de espacialidade e fisicalidade associada à introdução de um novo tipo de impacto digital, condicionaram a forma como se pensam, interna e externamente, os museus. No rescaldo desta crise, urge refletir sobre possíveis evidências quanto à verdadeira dimensão dos impactos desta pandemia na perceção dos museus. De que 
modo a pandemia veio mudar mentalidades face aos museus? De que forma as pessoas se relacionarão com os museus no futuro?

\section{Referências}

- Appadurai, A. (1996). Dimensões Culturais da Globalização. A Modernidade sem Peias. Lisboa: Editorial Teorema.

- Baker, K. (2013). Information Literacy and Cultural Heritage. Developing a Model for Lifelong Learning. Oxford: Chandos Publishing.

- Benjamin, W. (2008). The Work of Art in the Age of Mechanical Reproduction (J. A. Underwood, Trans.). London: Penguin Books.

- Bourdieu, P., \& Darbel, A. (2003). O Amor pela Arte: os Museus de Arte na Europa e seu Público (G. J. d. F. Teixeira, Trans.). São Paulo: Zouk.

- Cruz, M. T. (2016). A nova economia criativa: design social e cultura da participação. In T. D. Martinho, J.T. Lopes \& J. L. Garcia (Orgs.), Cultura e Digital em Portugal (pp. 39-50). Porto: Edições Afrontamento.

- Duarte, A. (2013). Nova Museologia: os pontapés de saída de uma abordagem ainda inovadora. Revista Eletrónica do Programa de Pós-Graduação em Museologia e Património - PPG-PMUS Unirio /MAST, 6(1), 99-117.

- Falk. J., \& Dierking, L. (2000). Learning from Museums. Visitor Experiences and the Making of Meaning. Oxford: Altamira Press.

- Falk, J., Dierking, L., \& Adams, M. (2006). Living in a learning society: museums and free-choice learning. In S. MacDonald (Ed.), A Companion to Museum Studies (pp. 323-339). Oxford: Blackwell Publishing.

- Gere, C. (2008). Digital Culture. London: Reaktion Books.

- Hooper-Greenhill, E. (2006). Studying visitors. In S. MacDonald (Ed.), A Companion to Museum Studies (pp. 362-376). Oxford: Blackwell Publishing.

- Lopes, J. T. (2016). Participação sociocultural e mundos digitais: novas oportunidades, novos constrangimentos. In T. D. Martinho, J.T. Lopes \& J. L. 
Garcia (Orgs.), Cultura e Digital em Portugal (pp. 183-192). Porto: Edições Afrontamento.

- MacDonald, S. (Ed.). (2006). A Companion to Museum Studies. Oxford: Blackwell Publishing.

- Mason, R. (2016). Cultural theory and museum studies. In S. MacDonald (Ed.), A Companion to Museum Studies (pp. 17-32). Oxford: Blackwell Publishing.

- Miller, V. (2011). Understanding Digital Culture. London: SAGE.

- Network of European Museum Organisations (2020). Survey on the Impact of the COVID-19 Situation on Museums in Europe. Disponível em: https://www.nemo.org/advocacy/our-advocacy-work/museums-during-covid-19.html

- Oleiro, M. B. (2005). Apresentação. In A. Semedo \& J. T. Lopes (Coord.). Museus, Discursos e Representações. Porto: Edições Afrontamento.

- Parry, R. (Ed.) (2010), Museums in a Digital Age. Leicester Readers in Museum Studies. London: Routledge.

- Rodley, E., Stein, R., \& Cairns, S. (Eds.). (2015). CODE / WORDS. Technology and Theory in the Museums. Edinburgh: MuseumsEtc.

- Sandell, R. (Ed.). (2002). Museums, Society, Inequality. New York: Routledge.

- Silvaggi, A., \& Pesce, F. (Eds.). (2017). Museum Professionals in the Digital Era. Agents of Change and Innovation. Mu.SA Project. Disponível em: http://www.project-musa.eu/results/.

- Teixeira, M. L. (2020). Os Impactos da Cultura Digital na Comunicação em Museus. Um Olhar sobre a Comunicação Digital dos Museus Nacionais em Portugal. Porto: Faculdade de Letras da Universidade do Porto. Disponível em: https://repositorio-aberto.up.pt/handle/10216/130636

- United Nations Educational, Scientific and Cultural Organization (2020). Museums Around the World in the Face of COVID-19. Paris: UNESCO. Disponivel em: https://unesdoc.unesco.org/ark:/48223/pf0000373530 
Amaral, L. (2021). Museus, responsabilidade social e a pandemia da COVID-19. In P. M. Homem, B. Andrez, G. Soares, \& L. Amaral (Eds.), Ensaios e Práticas em Museologia (Vol. 10, pp. 01-18). Porto: FLUP/DCTP/MMUS. https://doi.org./10.21747/978-989-9082-06-9/102021a1

- Wong, A. (2012). Social media towards social change. Potential and challenges for museums. In R. Sandell \& E. Nighingale (Eds.), Museums, Equality and Social Justice (pp. 281-293). New York: Routledge. 


\section{Isabel Silva \\ m.isabelcardososilva@gmail.com}

Em torno da musealização do património cultural religioso. 


\section{Resumo}

O presente artigo foca o processo de musealização do património cultural religioso. Numa primeira fase, aborda-se os contornos e práticas que a musealização do património cultural religioso assumiu desde o século XVIII até à atualidade, refletindo sobre o modo como tais opções influenciaram a leitura e interpretação dos bens móveis e imóveis eclesiásticos. De seguida, é apresentado o caso ilustrativo do Museu de Arte Sacra da Capela da Lapa (Vila Nova de Famalicão) e parte da metodologia adotada na elaboração de uma proposta museológica, realizada no âmbito do Mestrado em Museologia (MMUS) da Faculdade de Letras da Universidade do Porto (FLUP).

Palavras-chave: Musealização; Património cultural religioso; Museu de Arte Sacra da Capela da Lapa

\section{Nota biográfica}

Isabel Silva é licenciada em História da Arte e mestre em Museologia pela Faculdade de Letras da Universidade do Porto (FLUP). Para a conclusão do 2 ำ ciclo de estudos em Museologia, desenvolveu um projeto intitulado “Museu de Arte Sacra da Capela da Lapa: proposta museológica participativa" sob a orientação da Prof. Doutora Alice Duarte e do Prof. Doutor Pedro Borges de Araújo.

\section{Abstract}

The present article refers to the process of musealization of religious cultural heritage, more particularly, its developments from the $18^{\text {th }}$ century to the present day. The initial stage approaches the outlines and practices that the musealization of religious cultural heritage assumed over time, reflecting on how those methods influenced the reading and interpretation of ecclesiastical movable and immovable assets. In a second stage, the article presents the illustrative case of the Museum of Sacred Art of Capela da Lapa (Vila Nova de Famalicão) and part of the methodology adopted in the development of a museological proposal, carried out within the Masters in Museology (MMUS) of the Faculty of Arts and Humanities of the University of Porto (FLUP).

Keywords: Musealisation; Religious cultural heritage; Museu de Arte Sacra da Capela da Lapa

\section{Biographical note}

Isabel Silva has a degree in History of Art and a Master in Museology from the Faculty of Arts and Humanities of the University of Porto (FLUP). For the completion of the 2nd cycle of studies in Museology, she developed a project entitled "Museu de Arte Sacra da Capela da Lapa: proposta museológica participativa" under the guidance of Professor Alice Duarte and Professor Pedro Borges de Araújo. 


\section{Introdução}

A musealização do património cultural religioso é um processo complexo e delicado. Isso deve-se, sobretudo, à forte ligação afetiva e espiritual que a comunidade crente tem para com os bens imóveis e móveis eclesiásticos. Atualmente, tem-se consciência do peso simbólico do património cultural religioso, procurando equacioná-lo na sua musealização. Até chegar a essa realidade, o processo de musealização de espaços e objetos religiosos sofreu profundas alterações ao nível das suas perspetivas e estratégias (Roque, 2011).

Esta premissa foi alvo de uma breve reflexão no projeto final do Mestrado em Museologia (MMUS) da Faculdade de Letras da Universidade do Porto (FLUP), que consistiu na elaboração de uma proposta museológica para o Museu de Arte Sacra da Capela da Lapa (MASCL), em Vila Nova de Famalicão. Não obstante, no presente artigo, aquela premissa é o principal mote de discussão. Ao explanar os desenvolvimentos da musealização do património cultural religioso, pretende-se sensibilizar para o impacto que as suas práticas têm na interpretação sobre os bens eclesiásticos.

Num primeiro momento são elencadas as etapas deste processo, seguindo-se uma análise dos seus respetivos efeitos. Para a elaboração da parte inicial, foi crucial a consulta da Carta Circular - A Função Pastoral dos Museus Eclesiásticos (CPBCl, 2001) e o desenvolvimento de algumas ideias defendidas no projeto de mestrado (Silva, 2020). Já num segundo e último momento do artigo, é procurado um paralelismo entre as diversas fases de musealização do património cultural religioso, antes identificadas, com os desenvolvimentos museológicos ocorridos no próprio MASCL entre a década de 1990 e o ano de 2020. 


\section{Os percursos da musealização do património cultural religioso}

A musealização do património cultural religioso iniciou-se, sensivelmente, no século XVIII. A partir dessa época, fruto dos contextos políticos, sociais e culturais da modernidade, é reconhecido aos objetos produzidos e conservados pela Igreja Católica - desde pinturas, mobiliário, têxteis e ourivesaria - um cunho patrimonial, que lhes confere a dignidade necessária para poderem ser estudados e expostos no âmbito das instituições museológicas. Ao integrarem os museus, os objetos perdem a sua esfera funcional e religiosa e adquirem novos significados e funções. Com base nesse estatuto de objeto museológico, quando, nos finais do século XVIII, as peças eclesiásticas entram no museu, o destaque é atribuído às suas características formais e estéticas, valendo-Ihes a sua integração numa nova categoria: objetos de arte sacra (Roque, 2011).

Em Portugal, esta via de musealização vai acentuar-se devido a dois acontecimentos históricos nacionais. O primeiro ocorre no século XIX, mais especificamente a 30 de maio de 1834, dia em que é promulgado o decreto da extinção das Ordens Religiosas, no contexto das políticas liberais. Trata-se de um longo processo de nacionalização de uma vasta quantidade de bens eclesiásticos, cuja expropriação é determinada em função da sua magnificência de fabrico e matérias-primas. Tal operação levará à dispersão de muitos objetos religiosos, sendo os seus destinos os mais variados. Enquanto um terço dos objetos metálicos retirados das Ordens Religiosas extintas são entregues à Casa da Moeda para serem refundidos, outros são vendidos a particulares. Há ainda peças religiosas que acabam por ser devolvidas às instituições eclesiásticas, por não lhes ser reconhecido nenhum labor artístico e/ou material interessante. Já sobre os bens que foram entregues a instituições de ensino e cultura, tem-se conhecimento de que 207 deles foram integrados em coleções museológicas como peças de arte sacra (Costa, 2011; Roque, 2011).

À medida que os museus portugueses vão formando as suas coleções de arte sacra, aquela tendência de musealização é a principal, se não a única, que molda os seus 
contornos e institui-se como a matriz de musealização de todo o património cultural religioso. Torna-se então recorrente um conjunto de estratégias expositivas como, por exemplo, o uso generalizado da vitrina como suporte expositivo - que enfatizam, propositadamente e em exclusivo, os atributos artísticos e materiais dos objetos (Roque, 2011).

Este modo de valorização do património religioso vai ser ainda reforçado em virtude de um segundo acontecimento relevante no contexto histórico português. No dia 20 de abril de 1911 é promulgada a Lei de Separação do Estado das Igrejas, consequência da implantação da República, o que desencadeou uma nova vaga de nacionalização de bens religiosos. Só que desta vez, a operação incluía também a expropriação pelo Estado de muitos templos católicos, os quais seriam convertidos em museus regionais (Costa, 2011; Roque, 2011). Quer se tratasse de antigos templos católicos convertidos em museus, quer de espaços sem nenhuma ligação eclesiástica, esta vertente de musealização continua a desenvolver estratégias como a "ordenação por tipologias materiais; critérios decorativos a presidir ao arranjo museográfico; e uma exaustiva ocupação do espaço expositivo" (Roque, 2011, p. 136).

A aplicação regular e repetida destas práticas vai contribuir significativamente para a construção do clássico "museu de arte sacra". Trata-se de um modelo museológico que procede à completa descontextualização dos objetos expostos, sendo a maioria deles de cariz litúrgico e ritual. Por exaltar as dimensões estético-formais, o museu de arte sacra oculta, intencionalmente, outras dimensões. Entre elas destacam-se as dimensões litúrgica, ritual ou devocional, através das quais seria possível proporcionar uma contextualização teológica e social dos objetos. Torna-se, assim, evidente que a valorização da componente artística e material condiciona a leitura e interpretação do visitante sobre estes objetos religiosos, orientando-o a encará-los exclusivamente como objetos de arte sacra (Roque, 2011; Silva, 2020).

Pode dizer-se, portanto, que, durante um vasto período de tempo, a valorização da dimensão estético-formal dominou o processo de musealização do património cultural 
religioso. Na segunda metade do século $X X$, contudo, o movimento teórico-reflexivo surgido e designado Nova Museologia vai impulsionar uma nova postura museológica, cujos efeitos se farão sentir também neste âmbito. Ao questionar as práticas realizadas desde a época iluminista, este movimento defende a necessidade urgente de desenvolver estratégias alternativas que promovam uma contextualização mais consciente dos objetos expostos. Além disso, a Nova Museologia advoga que o museu, como uma instituição multifacetada, deve assumir um papel mais ativo na sociedade, procurando estabelecer uma estreita relação com os seus públicos e comunidades circundantes. Ora, todo este movimento de reformulação museológica vai, por sua vez, incentivar uma autorreflexão interna da própria Igreja Católica acerca da musealização do património cultural religioso. Em 2001, a Comissão Pontifícia para os Bens Culturais da Igreja (CPBCI) publica uma Carta Circular, intitulada A Função Pastoral dos Museus Eclesiásticos. As orientações defendidas neste documento dirigem-se aos museus eclesiásticos - ou seja, a instituições museológicas tuteladas pela Igreja Católica -, mas elas podem também fazer eco nos demais museus que estudam e expõem objetos religiosos (CPBCl, 2001; Roque, 2011).

Ciente dos inconvenientes ou limitações resultantes da musealização dos bens religiosos realizada até então, a Carta Circular questiona as práticas correntes, propondo uma mudança de paradigma que acrescenta uma nova vertente de musealização. É constatável que os seus argumentos se encontram em plena sintonia com os ideais da Nova Museologia. Há uma notória vontade de, não só alterar o modo como os bens eclesiásticos são estudados e expostos ao público, como também de procurar fomentar a relação entre o museu, os seus visitantes e a comunidade envolvente (CPBCl, 2001; Silva, 2020).

Em vez de defender a valorização das componentes artísticas, estéticas e materiais do património cultural religioso, a nova via de musealização proposta dirige o seu foco para a componente simbólica e ritual dos bens. Faz notar que tanto a seleção dos objetos a serem expostos, como a sua museografia, narrativa expositiva, suportes expositivos e discurso expositivo devem servir para elucidar os visitantes acerca das 
dimensões litúrgicas, devocionais e teológicas dos objetos em questão. Com isto não se pretende renunciar às dimensões estéticas e formais dos bens eclesiásticos, mas antes priorizar a sua dimensão simbólica e ritual (CPBCI, 2001).

Considerando esta nova via de musealização, os museus que se instalam em antigos templos católicos têm uma possibilidade acrescida de providenciar uma contextualização mais percetível acerca das componentes primárias dos bens, por comparação com aqueles que se instalam em edifícios de natureza profana. Verifica-se que, no primeiro caso, como o museu detém o espaço nativo dos objetos religiosos, beneficia de uma combinação de disposições que consegue estabelecer uma relação harmoniosa entre os bens móveis e o próprio imóvel e que possibilita uma interpretação mais imediata da função e sentido teológico dos objetos (Roque, 2015). Para que este modelo expositivo se concretize com sucesso, é necessário, porém, alcançar um equilíbrio entre a linguagem arquitetónica e formal do espaço e a natureza das coleções. Caso contrário, os visitantes podem ter dificuldade em identificar o espaço como museológico, visto que parece evocar um ambiente estritamente religioso (Capurro, 2018).

Dar predominância à componente ritual e simbólica, permite enfatizar o sentido espiritual e devocional do património religioso. Na Carta Circular, esse sentido espiritual é explicitamente referido como "função pastoral", isto é, os bens eclesiásticos devem servir o propósito de evangelizar as pessoas (CPBCl, 2001). Tal premissa pode, à primeira vista, suscitar polémica na esfera museológica. Nenhum museu, independentemente da sua tutela ou tipologia de coleções, deve assumir como sua principal função a doutrinação de princípios e valores que, por definição, não são universais e, portanto, podem ferir suscetibilidades de visitantes de outras crenças e culturas. No entanto, importa compreender que esta função pastoral não precisa de ser identificada em absoluto como uma catequização. Para lá dos seus contornos rituais, ela pode atuar como um catalisador de reflexão sobre questões espirituais, humanistas e antropológicas gerais. Repare-se igualmente que, ao compreender a função devocional e a simbologia de um objeto, consegue-se aceder a 
um conjunto de informações que permite compreender os comportamentos, a mentalidade, a cultura de uma determinada comunidade, neste caso, a comunidade cristã, mas cuja abordagem pode ser feita em termos muito mais interculturais ou transculturais. Aliás, todas as reflexões suscitadas podem ter grande amplitude. Através do destaque concedido ao sentido pastoral e/ou ritual de um objeto, o público pode ser levado a refletir sobre questões como a condição humana, as noções do Bem e do Mal, ou sobre a pluralidade de comportamentos aceites e praticados em sociedade (Silva, 2020).

Adicionalmente, a Carta Circular procura incentivar os museus com coleções de natureza religiosa a desenvolverem colaborações com outras instituições eclesiásticas e civis (CPBCl, 2001). Especifica-se a natureza diversa que estas instituições devem ter para realçar a importância de incluir a comunidade crente e não-crente no espaço museológico. Por haver uma partilha de crenças e valores entre o património religioso exposto e a comunidade crente, pode subsistir a ideia de que o museu deve uma maior atenção ao seu público cristão. Tal priorização é defendida na Carta Circular, mas, ainda assim, é tido como fundamental que os museus não permitam que esses laços espirituais e afetivos anulem a sua relação com a comunidade não-crente. Daí ser necessário que, das parcerias estabelecidas, surjam projetos museológicos inclusivos. Isso significa que se aplicarão as mesmas abordagens participativas a todos os seus visitantes e membros da comunidade envolvente, independentemente das suas culturas e crenças (Silva, 2020).

Com efeito, seguir esta via de musealização obriga os museus com objetos religiosos a repensar e reorganizar as suas abordagens e práticas. Pode, até, considerar-se que ela estabelece um renovado modelo museológico. Da mesma forma que a primeira tendência de musealização do património religioso deu origem ao clássico museu de arte sacra, também a nova vertente de musealização poderá ser associada ao museu eclesiástico. Entenda-se que tal designação não deve servir apenas para referir as instituições museológicas tuteladas pela Igreja Católica. Como anteriormente 
mencionado, a designação museu eclesiástico será a tradução de um novo modelo de musealização do património cultural religioso (Silva, 2020).

Compreende-se, então, que, atualmente, a musealização do património cultural religioso se tenha tornado alvo de discussão contínua, estando as suas metodologias e estratégias submetidas a uma constante avaliação. Por mais obstáculos e desafios que surjam durante o processo de musealização de um bem eclesiástico, móvel ou imóvel, cada vez mais se torna evidente a necessidade de aplicação de duas boas práticas para que se garanta a obtenção dos resultados desejados. A primeira remete para a consideração de todas as dimensões dos bens religiosos - não apenas a estética e artística, mas também a ritual, simbólica, material, histórica, etc. - todas tidas como merecedoras de consideração e destaque. Só assim, os visitantes receberão as informações necessárias para poderem usufruir e interpretar os bens eclesiásticos na sua totalidade significativa. Quanto à outra boa prática, é crucial que o museu procure incluir na sua programação a comunidade crente e a não-crente, de modo a conseguir reunir um conjunto de perspetivas e reflexões que, pela sua diversidade, culminem em projetos culturais inovadores, inclusivos e interativos (Roque, 2011; Silva, 2020).

\section{De capela a museu: o caso do Museu de Arte Sacra da Capela da Lapa}

No centro da cidade de Vila Nova de Famalicão encontra-se o MASCL (Fig. 1). A sua tutela pertence à Paróquia de Santo Adrião de Vila Nova de Famalicão e ao Município de Vila Nova de Famalicão, cujo protocolo de gestão partilhada foi assinado no dia 8 de maio de 2012 (Câmara Municipal de Vila Nova de Famalicão, 2012a). Posteriormente, no dia 26 de novembro de 2012, foi assinada a Declaração de Princípios que integra o MASCL na Rede de Museus de Vila Nova de Famalicão (RMVNF) (Câmara Municipal de Vila Nova de Famalicão, 2012b). 


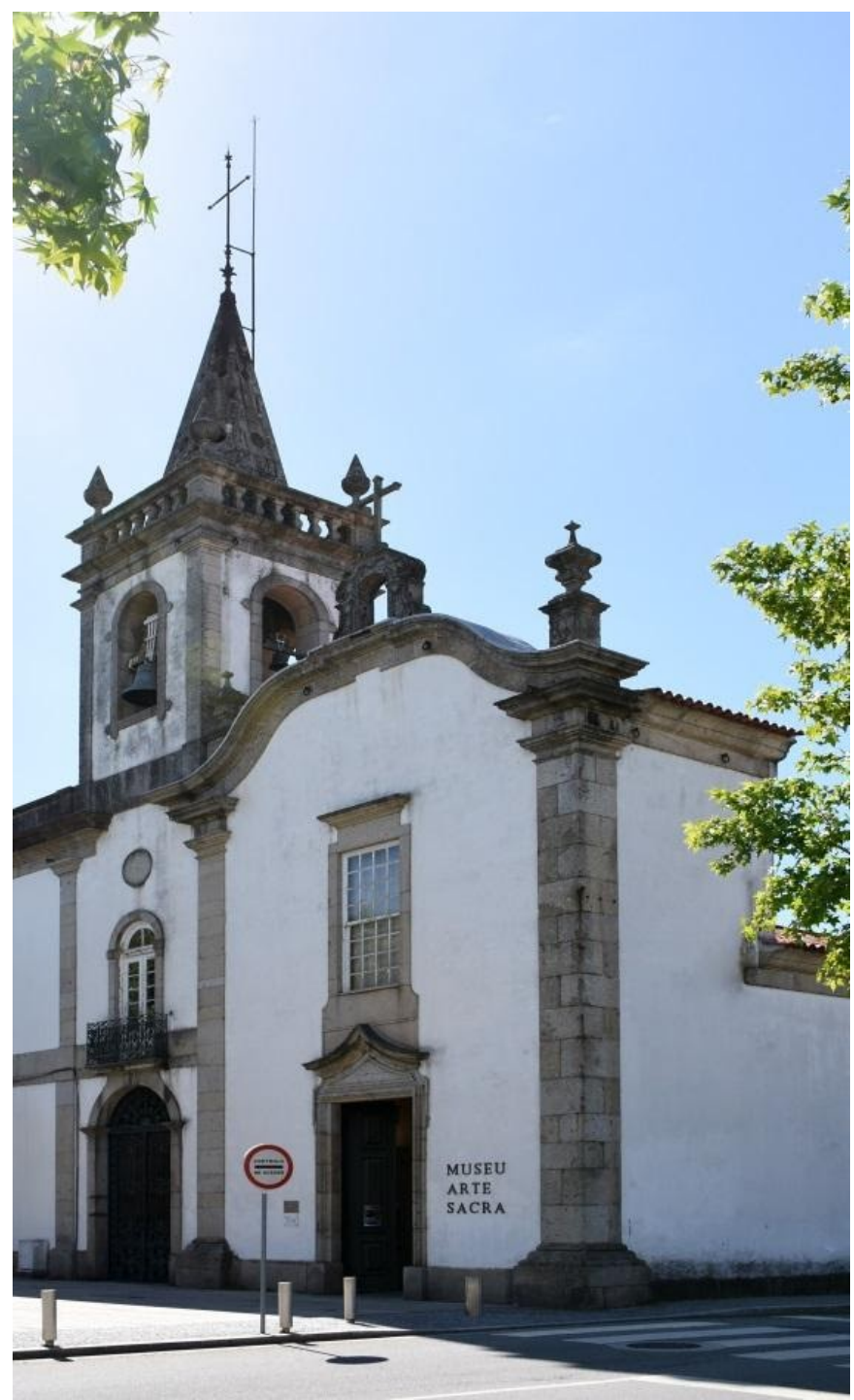

Fig. 1 - Fachada do Museu de Arte Sacra da Capela da Lapa. (C) Município de Vila Nova de Famalicão, 2017.

O edifício que alberga o Museu foi, em tempos, uma antiga capela que, desde o século $X V I$ até finais do século XX desempenhou funções litúrgicas e mortuárias. Com o objetivo de reanimar este espaço, tão acarinhado pela comunidade famalicense, decidiu-se converter o antigo templo católico num museu de arte sacra. Em 1995, iniciou-se a musealização da Capela da Nossa Senhora da Lapa. Primeiramente, foi necessário realizar obras de intervenção de restauro no edifício, visto que já se encontrava num estado de deterioração avançado. Foi deliberado manter a estrutura arquitetónica da capela, bem como os seus equipamentos litúrgicos, nomeadamente, o púlpito, os altares e o coro-alto. Ainda assim, houve a necessidade de adaptar o 
espaço às suas novas funções museológicas. Para esse efeito, foi instalada uma nova rede elétrica que servisse a iluminação, o som e os alarmes de incêndio e intrusão e um guarda-vento, que ajudou à delimitação da área de receção à entrada do espaço. Em simultâneo com estes trabalhos, foram também desenvolvidas intervenções de restauro nos altares e nos objetos de natureza religiosa (Vieira, 2009). Conforme o processo ia avançando, tornava-se evidente que todos os procedimentos convergiam para o enaltecimento da componente estético-formal dos bens eclesiásticos detidos. Aliás, pretendia-se que o novo museu atuasse como um centro cultural, mas isso era tido como implicando uma musealização regida em exclusivo por uma perspetiva de história da arte (Silva, 2020).

Depois de dois anos de um longo processo de musealização, o MASCL é inaugurado no dia 21 de novembro de 1997 (Vieira, 2009). Pelas antigas áreas litúrgicas - nave e presbitério - o museu distribui os objetos em plintos e vitrinas (Fig. 2), cujas amplas dimensões congestionam o espaço expositivo. Só algumas peças religiosas é que são exibidas nas balaustradas dos altares. Para além disso, a ausência de qualquer narrativa expositiva oculta a relação direta do espaço com os equipamentos litúrgicos e com os objetos. Mesmo que a maioria destes provenha da antiga capela e se relacione com os altares, essa ligação não é transmitida aos visitantes. Por tudo isto, o olhar do público vai estar condicionado a atender somente à componente estéticoformal destes bens eclesiásticos. 


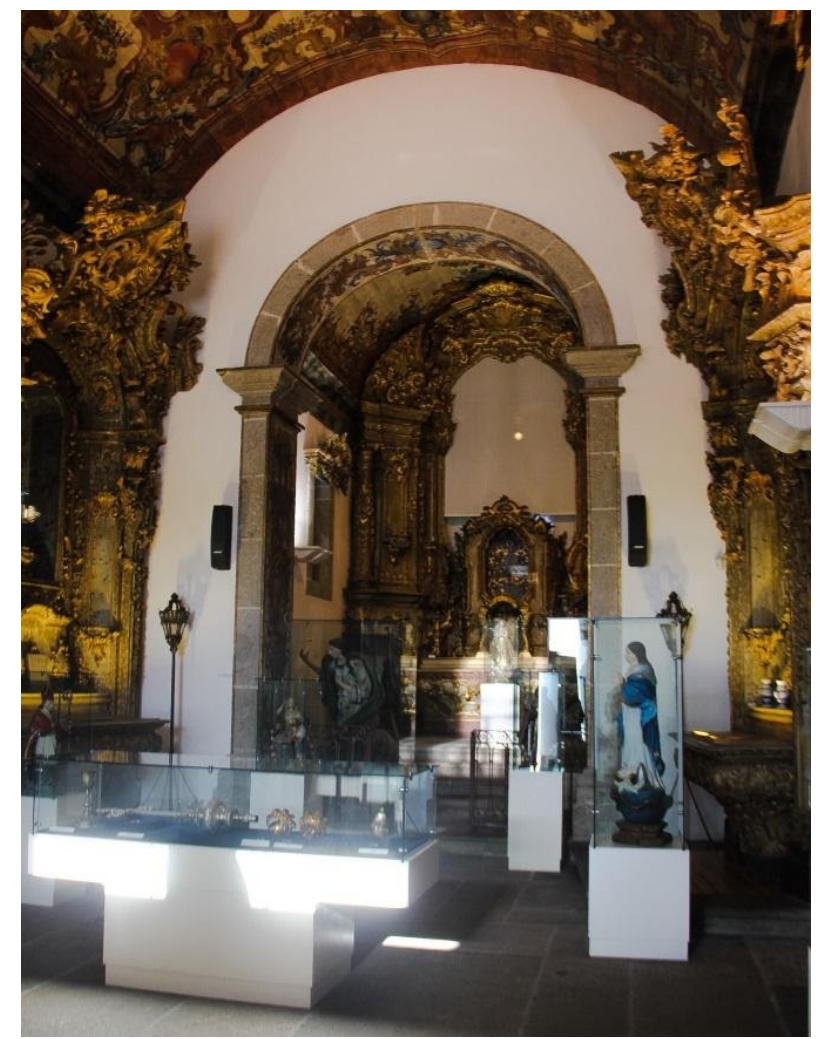

Fig. 2 - Espaço expositivo do Museu de Arte Sacra da Capela da Lapa. CIsabel Silva, 2020.

Por parte da comunidade famalicense houve dificuldade em aceitar o novo espaço museológico. Convém esclarecer que a Capela da Nossa Senhora da Lapa e os objetos religiosos que acolhia eram muito estimados pelos famalicenses. Devido a essa forte ligação afetiva e espiritual, a comunidade local continuou a perspetivar e a visitar o espaço, não como um museu, mas como o templo católico que outrora foi. Esta resistência dos famalicenses para com o MASCL fez com que se estabelecesse uma relação distante entre ambos.

Estes aspetos mais vulneráveis do MASCL estiveram na génese do projeto realizado no âmbito do 20 ciclo de estudos em Museologia da FLUP. O projeto dividia-se em duas vertentes: criar um plano estratégico de aproximação à comunidade local e repensar o espaço expositivo do museu, propondo uma nova exposição.

Era ponto assente que o planeamento da nova proposta museológica devia contar com a colaboração da comunidade famalicense. Em virtude da pandemia de COVID-19 e do 
primeiro confinamento obrigatório, decretado em Portugal a partir de março de 2020, a auscultação à comunidade só foi possível de forma indireta e com o auxílio da RMVNF. Devido à impossibilidade de contactar diretamente com os grupos comunitários, a RMVNF facilitou o envio de um documento a pessoas e entidades representativas de várias instituições e grupos de público de Vila Nova de Famalicão, no qual reunia as ideias e sugestões de iniciativas pensadas até então. Esta rede de contactos foi identificada e contactada com a ajuda da RMVNF e da equipa do MASCL. Após o envio desse documento, ocorreram duas reuniões via plataforma online Zoom. O principal objetivo destes encontros virtuais era recolher os comentários e as contribuições do grupo de intervenientes. De carácter interdisciplinar, este grupo incluía representantes da comunidade educativa famalicense, da área dos equipamentos culturais (RMVNF, Museu Cerâmica Artística da Fundação Castro-Alves, Galeria Municipal Ala da Frente e Associação Cultural Fértil), da área religiosa (Paróquia de Santo Adrião, ao nível da catequese e da equipa museológica) e da área social (Grupo Sénior do Município de Vila Nova de Famalicão e Associação dos Moradores de Lameiras). Em resultado destas duas reuniões conseguiu-se uma troca de impressões que foi extremamente profícua e imprescindível. Ao conjunto das iniciativas que tinha proposto, foi aconselhado o acréscimo de um cronograma, de modo a tornar mais percetível a regularidade e sequência das atividades propostas. Foi também sugerido o planeamento de estratégias comunicativas e de materiais mediadores associados à exposição, e ainda, a definição de um perfil para os mediadores culturais, cuja ação decorrerá no MASCL.

Posteriormente a estes encontros, foram contactados, de forma individualizada, os intervenientes da área social e educativa. Pretendia-se compreender melhor quais as necessidades e expetativas dos dois principais públicos-alvo do MASCL: o público infantojuvenil e o público sénior. As informações obtidas revelaram-se cruciais para pensar em iniciativas que suscitassem o interesse destes públicos e, em simultâneo, respeitassem as características particulares dos mesmos. 
Graças a estes diálogos frutuosos, foi possível planear um conjunto de exposições temporárias e um programa de atividades que apelam à participação ativa da comunidade no MASCL. Estas iniciativas podem ser divididas em dois grupos. $\mathrm{O}$ primeiro, reúne atividades e exposições cuja realização está a cargo da equipa dos serviços educativos do MASCL. Já o segundo grupo, acolhe iniciativas organizadas e concretizadas em colaboração com grupos sociais e artísticos famalicenses, ou com unidades museológicas pertencentes à RMVNF.

Quanto à proposta de reformulação do espaço expositivo, o objetivo central foi reorganizar a museografia e a exposição patente, de modo a proporcionar uma contextualização mais coerente. Desde logo, foi estudada a possibilidade de expandir o espaço expositivo do Museu, ocupando para essa função outras áreas que, ou se encontravam inativadas, ou não eram devidamente aproveitadas. Assim, às duas áreas expositivas já existentes, adicionaram-se mais três. Esta ampliação e renovação espacial permitiu distribuir os objetos da coleção por outras áreas, cuja natureza promove uma melhor compreensão das funções primárias dos bens e do seu sentido teológico. Por exemplo, enquanto a maior parte das imagens devocionais se manteve na antiga nave e presbitério, sugeriu-se que os paramentos litúrgicos fossem expostos na antiga sacristia, local onde eram originalmente armazenados. Um outro aspeto que também teve de ser repensado foi o dos suportes expositivos. Com a intenção de aproveitar os recursos já existentes no MASCL, propôs-se que algumas das vitrinas fossem substituídas por outros suportes expositivos. Entre eles, destacam-se os altares, por conseguirem evidenciar os significados simbólicos dos objetos expostos. Para que todo o espaço expositivo permitisse uma circulação mais fluída, sugeriu-se a instalação de novos suportes expositivos na parede. Tanto a nova disposição expositiva proposta, como o desenho dos novos suportes expositivos, foram concebidos em colaboração com um dos intervenientes nas reuniões mencionadas, cujo desempenho profissional abrangia as funções artísticas e de curadoria. Importa salientar que, aceitando o conselho formulado pelo grupo de representantes locais, esta reestruturação expositiva foi planeada com a inclusão de um material mediador. Para 
a exposição permanente e para cada uma das exposições temporárias propostas, indicou-se um recurso comunicativo que fornecesse um contexto sociocultural e religioso dos objetos expostos, de forma dinâmica e recreativa.

Verifica-se, portanto, que o MASCL passou por duas fases museológicas distintas, as quais são, em si mesmas, ilustrativas dos desenvolvimentos de musealização do património cultural religioso, enunciados no início deste artigo. Enquanto a musealização pela valorização artística e estética dominou de forma bastante flagrante o processo inicial de musealização da antiga capela e seus objetos religiosos, a via da musealização pela inclusão da vertente simbólica e devocional orientou o planeamento da proposta de renovação museológica. Por assumirem posturas e metodologias diferentes, estas duas fases de musealização do MASCL produzirão leituras e interpretações distintas acerca dos bens eclesiásticos expostos. A musealização ocorrida na década de 1990 orientava os visitantes a encararem o espaço, os equipamentos litúrgicos e os objetos expostos de forma isolada e como obras de arte sacra. Por sua vez, a renovação museográfica proposta durante o projeto de mestrado procura enfatizar a interligação entre aqueles três elementos, providenciando uma representação mais coerente e mais contextualizada de diversas dimensões dos bens eclesiásticos. Ao contrário da primeira fase de musealização do MASCL, a proposta museológica foi planeada em colaboração com os grupos comunitários de Vila Nova de Famalicão, pois, de outra forma, não faria sentido. Com as contribuições do projeto final, o MASCL pode aproximar-se das realidades e necessidades da comunidade local.

\section{Considerações finais}

O percurso de musealização do património cultural religioso já é longo, mas ainda não deve ser dado por terminado. Desde o século XVIII até aos tempos atuais, desenvolveram-se duas vias de musealização dos bens religiosos imóveis e móveis. 
Oriundas de contextos socioculturais distintos, estas tendências de musealização desencadearam critérios expositivos e práticas museológicas que, pela sua divergência, produzem resultados opostos. Por um lado, a valorização das componentes estéticoformais, que dominou desde o período iluminista e até finais do século $X X$, levou à conceção do objeto de arte sacra e, sequencialmente, do museu de arte sacra. Dentro deste espaço museológico, as peças litúrgicas e devocionais perdem a sua carga espiritual e são admiradas somente pelas características intrínsecas da suas matériasprimas e das suas técnicas artísticas. Por outro lado, decorrente dos ideais da Nova Museologia, surge a valorização destes objetos pela consideração da sua vertente simbólica, ritual e devocional. Através dela, os espaços e objetos eclesiásticos são celebrados pelas suas funções originais e seu sentido espiritual e teológico. Ao contrário da anterior, esta tendência de musealização, pela abordagem alargada de temáticas que proporciona, promove a inclusão das comunidades circundantes, crente e não-crente, no museu e a sua participação ativa.

Esta dupla via de musealização do património religioso está muito presente no percurso do MASCL. Aquando da sua criação, houve a intenção de que este novo espaço museológico impulsionasse o estudo dos objetos e da antiga Capela da Nossa Senhora da Lapa. Por essa razão, estes bens eclesiásticos foram musealizados pela via de valorização da sua vertente artística e material. Já em 2020, no âmbito de um projeto renovador, procurou-se desenvolver uma proposta que valorizasse todas as dimensões do edifício, dos equipamentos litúrgicos e dos objetos e que, simultaneamente, incentivasse a comunidade a participar nas atividades do MASCL. Com o apoio da RMVNF e da equipa museológica do MASCL conseguiu-se, ainda que indiretamente, auscultar alguns grupos comunitários famalicenses e recolher as suas perspetivas e conselhos. Sem esta colaboração, o projeto final não teria conseguido responder às necessidades e expetativas da comunidade de Vila Nova de Famalicão. 


\section{Agradecimentos}

A autora gostaria de expressar os seus mais sinceros agradecimentos à Professora Doutora Alice Duarte, pela sua paciência e maestria na orientação, a toda equipa da RMVNF e à Paróquia de Santo Adrião, pelo apoio prestado, e, por fim, ao grupo de representantes locais de Vila Nova de Famalicão, pela sua colaboração.

\section{Referências}

- Câmara Municipal de Vila Nova de Famalicão (2012a). Protocolo para a Gestão Partilhada do Museu de Arte Sacra (Capela da Lapa) de Vila Nova de Famalicão. Câmara Municipal. V. N. Famalicão.

- Câmara Municipal de Vila Nova de Famalicão (2012b). Declaração de Princípios. Câmara Municipal. V. N. Famalicão.

- Capurro, R. (2018). Reinterpreting a sacred place. When a church becomes a museum from an ecclesiastical point of view. In F. Mairesse (Ed.), Museology and the Sacred. Materials for a Discussion (pp. 49-53). Paris: ICOFOM. Disponível em: http://icofom.mini.icom.museum/wpcontent/uploads/sites/18/2018/12/Icofom_mono_Sacred_version_nume_riq ue2.pdf

- Comissão Pontifícia para os Bens Culturais da Igreja [CPBCl] (2001). A Função Pastoral dos Museus Eclesiásticos. Disponível em: https://www.vatican.va/roman_curia/pontifical_commissions/pcchc/document s/rc_com_pcchc_20010815_funzione-musei_po.html

- Costa, A. M. R. P. d. (2011). Museologia da Arte Sacra em Portugal (1820-2010). Espaços, Momentos, Museografia. Tese de Doutoramento. Coimbra: Universidade de Coimbra. Disponível em: https://eg.uc.pt/handle/10316/18833 
- Roque, M. I. (2011). A exposição do sagrado no museu. Comunicação e Cultura: Sagrado e Modernidade, (11), 129-146. Disponível em: http://comunicacaoecultura.com.pt/wp-content/uploads/08.-Maria-IsabelRoque.pdf

- Roque, M. I. (2015). Musealizar o sagrado. Invenire: Revista de Bens Culturais da lgreja, (10), 54-56. Disponível em: http://www.revistainvenire.pt/revista/10\#invenire/11

- Silva, I. (2020). Museu de Arte Sacra da Capela da Lapa: Proposta Museológica Participativa. Relatório de Projeto de Mestrado em Museologia. Porto: FLUP. Disponível em: https://repositorio-aberto.up.pt/handle/10216/130672

- Vieira, A. M. (2009). História da Capela da Lapa e o museu. Boletim Cultural de Vila Nova de Famalicão, 5(III), 49-58. 


\section{Juliana Bittencourt \\ juvibit@gmail.com}

Centro Interpretativo do FEUPmuseu: um espaço de encontro 
Resumo

Este texto parte de uma reflexão sobre os museus universitários e apresenta-se como uma contribuição para a discussão acerca da pluralidade de características, dinâmicas e/ou modelos institucionais que os mesmos podem desempenhar. Fundamenta- se no pressuposto de que museu universitário possui um modo singular de se apresentar à sociedade face às dinâmicas próprias do ensino e investigação universitária; aos valores de cada universidade; e às funções básicas que um museu deve realizar. Define como contexto de análise o caso do Museu da Faculdade de Engenharia da Universidade do Porto (FEUPmuseu). Caracterizado como um modelo polinucleado, o FEUPmuseu integrará a sua estrutura um centro interpretativo e acentuará em seu discurso as dimensões de território, património e educação. Este será um novo espaço de encontro entre a comunidade FEUP, visitantes e a dimensão interpretativa e expositiva do património material e imaterial da faculdade.

Palavras-chave: Museu universitário; Centro interpretativo; Modelo institucional; FEUPmuseu; Património cultural

\section{Nota biográfica}

Juliana Bittencourt possui um Bacharelato em Administração, com foco em economia criativa e marketing, pela Escola Superior de Propaganda e Marketing no Rio de Janeiro, Brasil. É mestre em Museologia pela Faculdade de Letras da Universidade do Porto em Portugal, tendo desenvolvido o projeto intitulado "Centro Interpretativo do FEUPmuseu: contributo para a sua criação e para uma política de exposição", sob a orientação da Prof. Doutora Elisa Noronha.

\section{Abstract}

The purpose of this text is to provide a critical review and contribution to the discussion about the plurality of characteristics, dynamics and/or institutional models executed at university museums. Despite the dynamics of university teaching and research; the values of each university; and the basic functions that a museum must perform, it is assumed that each university museum has a unique way of presenting itself to the society. For investigation purposes, the museums of the University of Porto are analysed, specially focusing on the case of Museum of the Faculty of Engineering of the University of Porto (FEUPmuseu).

Characterized as a polynuclear model, the FEUPmuseu will integrate a Heritage Center into its model, and combine with its discourse the dimensions of territory, heritage, and education. This new space will be an intersection point between the FEUP community, visitors and the interpretive and expository dimension of the faculty's material and intangible heritage.

Keywords: University museum; Heritage center; Institutional model; FEUPmuseu; Cultural heritage

\section{Biographical note}

Juliana Bittencourt has a bachelor's degree in Business, with an emphasis in marketing and creative industries, by the Escola Superior de Propaganda e Marketing, Rio de Janeiro, Brazil. In additional, a master's degree in Museology from Faculty of Arts and Humanities of Porto University (FLUP), Porto, Portugal - with culminated at the project entitled "Centro Interpretativo do FEUPmuseu: contributo para a sua criação e para uma política de exposição", under guidance of Elisa Noronha. 


\section{Introdução}

Museus universitários são instituições comprometidas com a salvaguarda dos testemunhos tangíveis e intangíveis da atividade humana relacionados com o ensino superior. Representam a comunidade académica, os seus valores e realizações; bem como os seus modos de transmissão de conhecimento e capacidade de inovação (Council of Europe, 2005). Fundamentados em três pilares, ou orientados por três propósitos - ensino, investigação e exposição pública do seu acervo -, os museus universitários são, porém, mais do que agentes na preservação de uma memória coletiva institucional e mais do que meros intérpretes das suas coleções: são lugares que potencialmente contribuem para a construção da cidadania, de modo a promover o diálogo e a discussão sobre as problemáticas contemporâneas (Santos, 1994; Delicado, 2004; Semedo, 2005).

Enquanto instituições permanentes a serviço da sociedade e do seu desenvolvimento, os museus universitários desempenham funções comuns a museus de outras tipologias: adquirir, conservar, pesquisar, comunicar e exibir o património da humanidade e do seu meio envolvente com fins de educação, estudo e deleite (ICOM, 2007). Ou seja, para além de seus objetivos e necessidades estarem relacionados com os valores da instituição a qual pertence, um museu universitário deve (1) cumprir as funções de um museu, descritas acima; (2) preservar a memória científica, histórica e institucional da universidade; e (3) comunicar à sociedade o património universitário. Esta sua condição complexa é determinante para a definição dos modelos institucionais que assume (Lourenço, 2005).

Em outras palavras, cada museu universitário está associado ou comprometido com um contexto distinto e próprio e, consequentemente, atua neste contexto podendo desempenhar uma variedade de modelos institucionais. Entre os modelos institucionais existentes estão, por exemplo, o núcleo museológico, a galeria, a casamuseu, o centro de documentação e o museu. Com o objetivo de contribuir para a discussão acerca da pluralidade de características, dinâmicas e/ou modelos institucionais que os museus universitários podem desempenhar, esta reflexão propõe 
uma análise do modelo híbrido pretendido pelo Museu da Faculdade de Engenharia da Universidade do Porto (FEUPmuseu) constituído na intersecção entre um museu polinucleado e um centro interpretativo.

\section{Uma breve reflexão sobre os modelos institucionais dos museus da Universidade do Porto}

No final do século XVIII e início do século XX, os museus das universidades portuguesas eram pequenos, organizados por departamentos e com acesso limitado ao público. Os fatores que influenciaram o desenvolvimento dos museus e das coleções nas instituições académicas estavam associados às atividades de ensino e investigação, de modo a complementar de forma pedagógica as aulas (Lourenço \& Dias, 2017). Gil (2005) denomina estes espaços como "gabinete de curiosidades" (p. 42), que, por vezes, possuíam uma biblioteca e um laboratório exclusivo para auxiliar a investigação e o ensino acerca das coleções ali guardadas. A responsabilidade sobre tais objetos era de um professor ou do departamento académico (Clercq \& Lourenço, 2003).

Pode-se afirmar que, ainda hoje, muitos museus universitários portugueses seguem este modelo, mas não necessariamente assumem a mesma terminologia. Contudo, uma breve análise esquemática dos modelos institucionais existentes na Universidade do Porto (Tab. 1) auxilia na definição de um universo mais diversificado, fruto das dinâmicas próprias de cada museu universitário e da instituição que o está a tutelar faculdade ou departamento que o museu universitário está associado - , bem como, do modo como cada instituição académica percebe o seu patrónimo e os usos de suas coleções - para fins pedagógicos, para constituir e salvaguardar uma memória institucional, para auxiliar em novos projetos científicos, entre outros. 
Tab. 1 - Espaços museológicos da Universidade do Porto. Adaptada de Bittencourt (2020, p. 86).

\begin{tabular}{|c|c|c|c|c|}
\hline Instituição & Tutela & Natureza da coleção & Espaço expositivo & Tipologia \\
\hline $\begin{array}{l}\text { Museu de } \\
\text { História } \\
\text { Natural e } \\
\text { da } \\
\text { Ciência da } \\
\text { Universida } \\
\text { de } \\
\text { do Porto } \\
\text { (MHNC-UP) }\end{array}$ & $\begin{array}{l}\text { Reitoria da } \\
\text { Universidade do } \\
\text { Porto, com o } \\
\text { apoio da Ciência } \\
\text { Viva e Banco } \\
\text { BPI. }\end{array}$ & $\begin{array}{l}\text { Sua coleção é } \\
\text { Constituída pelas áreas } \\
\text { de conhecimento: geo- } \\
\text { logia, paleontologia, } \\
\text { zoologia, arqueologia e } \\
\text { etnografia, botânica e } \\
\text { ciência. }\end{array}$ & $\begin{array}{l}\text { Aberto ao público } \\
\text { com Programação } \\
\text { diversa. Bilhete de } \\
\text { entrada sob con- } \\
\text { sulta ao website. }\end{array}$ & $\begin{array}{l}\text { Estrutura Bipolar, O } \\
\text { MHNC-UP é consi- } \\
\text { derado o polo } \\
\text { central. Sua estru- } \\
\text { tura é baseada nas } \\
\text { premissas do Muse- } \\
\text { ologia total. }\end{array}$ \\
\hline $\begin{array}{l}\text { Galeria da } \\
\text { Biodiversi- } \\
\text { dade }\end{array}$ & $\begin{array}{l}\text { Reitoria da } \\
\text { Universidade do } \\
\text { Porto }\end{array}$ & $\begin{array}{l}\text { Seu património está } \\
\text { envolto aos temas da } \\
\text { biologia, história } \\
\text { natural e arte. }\end{array}$ & $\begin{array}{l}\text { Aberto ao público } \\
\text { com programação } \\
\text { diversa. bilhete de } \\
\text { entrada sob con- } \\
\text { sulta ao website. }\end{array}$ & $\begin{array}{l}\text { A Galeria está } \\
\text { integra a estrutura } \\
\text { do MHNC-UP. }\end{array}$ \\
\hline $\begin{array}{l}\text { Museu da } \\
\text { Faculdade } \\
\text { de } \\
\text { Belas } \\
\text { Artes }\end{array}$ & $\begin{array}{l}\text { Faculdade de } \\
\text { Belas Artes }\end{array}$ & $\begin{array}{l}\text { Sua coleção é } \\
\text { constituída por } \\
\text { esculturas, pinturas, } \\
\text { gravuras, objetos de } \\
\text { alunos e docentes, } \\
\text { bem como, artistas } \\
\text { consagrados. }\end{array}$ & $\begin{array}{l}\text { Aberta ao público, } \\
\text { Entrada livre. }\end{array}$ & $\begin{array}{l}\text { Museu de } \\
\text { Belas Artes. }\end{array}$ \\
\hline
\end{tabular}




\begin{tabular}{|c|c|c|c|c|}
\hline $\begin{array}{l}\text { Galeria } \\
\text { dos } \\
\text { Leões }\end{array}$ & $\begin{array}{l}\text { Faculdade de } \\
\text { Belas Artes } \\
\text { (FBAUP) }\end{array}$ & $\begin{array}{l}\text { Espaço destinado a } \\
\text { exposições, comer- } \\
\text { cialização e realização } \\
\text { de iniciativas dos estu- } \\
\text { dantes, docentes e } \\
\text { antigos alunos da } \\
\text { FBAUP. }\end{array}$ & $\begin{array}{l}\text { Aberta ao } \\
\text { público, entrada } \\
\text { livre. }\end{array}$ & Galeria. \\
\hline $\begin{array}{l}\text { Museu de } \\
\text { História da } \\
\text { Medicina } \\
\text { Prof. } \\
\text { Maximiano } \\
\text { Lemos }\end{array}$ & $\begin{array}{l}\text { Faculdade de } \\
\text { Medicina }\end{array}$ & $\begin{array}{l}\text { Sua coleção é cons- } \\
\text { tituída pela evolução } \\
\text { histórica da medicina } \\
\text { com o património } \\
\text { médico. }\end{array}$ & $\begin{array}{l}\text { Todas as visitas } \\
\text { são guiadas e } \\
\text { requerem marca- } \\
\text { ção prévia. }\end{array}$ & $\begin{array}{l}\text { Museu de } \\
\text { História. }\end{array}$ \\
\hline $\begin{array}{l}\text { Museu de } \\
\text { Anatomia } \\
\text { da } \\
\text { Faculdade } \\
\text { de } \\
\text { Medicina }\end{array}$ & $\begin{array}{l}\text { Unidade de } \\
\text { anatomia da } \\
\text { Faculdade de } \\
\text { Medicina }\end{array}$ & $\begin{array}{l}\text { Sua coleção é com- } \\
\text { posta por: fotografias, } \\
\text { radiografias, desenhos } \\
\text { e peças anatómicas } \\
\text { que documentavam } \\
\text { lições e artigos de } \\
\text { investigação. }\end{array}$ & $\begin{array}{l}\text { Todas as visitas } \\
\text { ao Museu são } \\
\text { guiadas e reque- } \\
\text { rem marcação } \\
\text { prévia, bilhete } \\
\text { de entrada sob } \\
\text { consulta ao } \\
\text { website. }\end{array}$ & $\begin{array}{l}\text { Museu de } \\
\text { Anatomia. }\end{array}$ \\
\hline
\end{tabular}




\begin{tabular}{|c|c|c|c|c|}
\hline $\begin{array}{l}\text { Museu de } \\
\text { Anatomia } \\
\text { Prof. Nuno } \\
\text { Grande }\end{array}$ & $\begin{array}{l}\text { Instituto de } \\
\text { Ciências } \\
\text { Biomédicas de } \\
\text { Abel Salazar }\end{array}$ & $\begin{array}{l}\text { Sua coleção é com- } \\
\text { posta pro modelos } \\
\text { anatómicos e peças } \\
\text { humanas e de animais. }\end{array}$ & $\begin{array}{l}\text { Acondicionado } \\
\text { em um núcleo mu- } \\
\text { seológico, suavisi- } \\
\text { ta é possível sob } \\
\text { marcação prévia. }\end{array}$ & $\begin{array}{l}\text { Núcleo } \\
\text { Museológico. }\end{array}$ \\
\hline $\begin{array}{l}\text { Casa- } \\
\text { Museu } \\
\text { Abel } \\
\text { Salazar }\end{array}$ & $\begin{array}{l}\text { Reitoria da } \\
\text { Universidade do } \\
\text { Porto e está } \\
\text { credenciado na } \\
\text { Rede Portuguesa } \\
\text { de Museus. }\end{array}$ & $\begin{array}{l}\text { Exposição perma- } \\
\text { nente das obras } \\
\text { artística, científica e } \\
\text { literária de Abel } \\
\text { Salazar. }\end{array}$ & $\begin{array}{l}\text { Aberto ao público } \\
\text { com visitas guia- } \\
\text { das. Bilhete de } \\
\text { entrada sob con- } \\
\text { sulta ao website. }\end{array}$ & Casa-Museu. \\
\hline $\begin{array}{l}\text { Museu da } \\
\text { Faculdade } \\
\text { de } \\
\text { Farmácia }\end{array}$ & $\begin{array}{l}\text { Faculdade de } \\
\text { Farmácia }\end{array}$ & $\begin{array}{l}\text { Sua coleção é compos- } \\
\text { ta por instrumentos } \\
\text { utilizados na atividade } \\
\text { farmacêutica, bem } \\
\text { como outras áreas } \\
\text { científicas. }\end{array}$ & $\begin{array}{l}\text { Acondicionado } \\
\text { em um Núcleo } \\
\text { Museológico, } \\
\text { sua visita é possí- } \\
\text { vel sob marcação } \\
\text { prévia. }\end{array}$ & $\begin{array}{l}\text { Núcleo } \\
\text { Museológico. }\end{array}$ \\
\hline $\begin{array}{l}\text { Centro de } \\
\text { Documen- } \\
\text { tação da } \\
\text { Faculdade } \\
\text { De Arqui- } \\
\text { tetura }\end{array}$ & $\begin{array}{l}\text { Faculdade de } \\
\text { Arquitetura }\end{array}$ & $\begin{array}{l}\text { Coleção com valor } \\
\text { patrimonial, histórico, } \\
\text { artístico ou documen- } \\
\text { tal relativos à arquite- } \\
\text { tura e urbanismo por- } \\
\text { tuguês e portuense. }\end{array}$ & $\begin{array}{l}\text { Acondicionado } \\
\text { em deposito. } \\
\text { Possível consultar } \\
\text { a partir de marca- } \\
\text { ção prévia. }\end{array}$ & $\begin{array}{l}\text { Centro de } \\
\text { Documentação } \\
\text { integrado ao } \\
\text { Serviços de } \\
\text { Documentação. }\end{array}$ \\
\hline
\end{tabular}




\begin{tabular}{|c|c|c|c|c|}
\hline FEUPmuseu & $\begin{array}{l}\text { Faculdade de } \\
\text { Engenharia do } \\
\text { Porto }\end{array}$ & $\begin{array}{l}\text { Sua coleção é centrada } \\
\text { Na engenharia portu- } \\
\text { guesa dos séculos XIX } \\
\text { e XX. }\end{array}$ & $\begin{array}{l}\text { Acondicionado em } \\
\text { espaços semipúbli- } \\
\text { cos, é possível con- } \\
\text { sultar ao circular } \\
\text { pela faculdade ou } \\
\text { com marcação } \\
\text { prévia. }\end{array}$ & $\begin{array}{l}\text { Caracteriza-se como } \\
\text { um museu polinu- } \\
\text { cleado, está a reunir } \\
\text { forças para se tor- } \\
\text { nar uma coleção } \\
\text { aberta. E integra } \\
\text { como uma unidade } \\
\text { nos SDI da } \\
\text { faculdade em } \\
\text { questão. }\end{array}$ \\
\hline
\end{tabular}

Através desta análise esquemática é possível observar que todos os espaços museológicos identificados acima colecionam objetos, instrumentos, documentos com valor científico e histórico, como também objetos de relevância artística e cultural, através dos quais atendem à história institucional das respetivas faculdades. São espaços que se diferenciam no modo de expor o património. Uns atribuem prioridade à dimensão interpretativa/comunicativa, como por exemplo, a Galeria da Biodiversidade que faz uso dos fundamentos da Museologia Total (Wagensberg, 2005).

Outros, como Museu de História da Medicina Prof. Maximiano Lemos, organizam a sua coleção exposta sob uma ótica histórica. Mais um distinto modelo identificado é o Centro de Documentação da Faculdade de Arquitetura, um espaço que não expõe, entretanto, condiciona o património em depósito a fim de preservá-lo e disponibilizálo à comunidade para investigação ou consulta. Observa-se igualmente que algumas instituições denominadas como museu classificam-se em outras tipologias. Por exemplo, o Museu de Farmácia classifica-se como núcleo museológico, tal qual o Museu de Anatomia Prof. Nuno Grande que ao mesmo tempo em que se classifica 
como núcleo museológico, descreve o seu espaço como "uma espécie de laboratório e sala de estudo" (Bittencourt, 2020), o que remete ao modelo de "gabinete de curiosidades", conforme já citado.

Para além dos modelos já citados, identifica-se entre os museus da Universidade do Porto outra tipologia de instituição museológica de ensino superior, exemplificada pelo FEUPmuseu. Tutelado pela Faculdade de Engenharia da Universidade do Porto (FEUP), o FEUPmuseu posiciona-se na sociedade como um museu universitário que atende a uma estrutura polinucleada, devido à dispersão do seu acervo. Hoje, o FEUPmuseu está a reunir recursos para poder se classificar como uma coleção visitável e pretende atingir esta meta com a criação de um centro interpretativo.

\section{FEUPmuseu}

O FEUPmuseu é um projeto em construção desde 2004. A sua gestão é da responsabilidade da Unidade de Museu, que por sua vez está integrada nos Serviços de Documentação e Informação (SDI) da FEUP. A Unidade de Museu é responsável pela gestão do património museológico da FEUP, pelas atividades culturais e pela exploração dos acervos documentais, da responsabilidade do SDI. Logo, à gestão do FEUPmuseu compete promover, apoiar e colaborar para a salvaguarda, estudo e divulgação do património museológico da FEUP. O FEUPmuseu possui, como valores do seu modo de trabalhar, as dimensões colaborativa, participativa e experimental; um reflexo dos valores do SDI. Responsável por artefactos com valor museológico da faculdade em questão, o FEUPmuseu trabalha de forma transversal, respeitando as polivalências pedagógicas, investigativas e patrimoniais que os objetos podem conter (Medina 2012; 2014).

Assim, o FEUPmuseu tem como objetivo preservar, documentar, interpretar e divulgar o acervo material e imaterial do seu acervo que são representativas da história, memória e identidade da FEUP (Medina, 2014). O FEUPmuseu trabalha de modo 
colaborativo com a comunidade docente, estudantes e investigadores, com a finalidade de transmitir e incentivar a produção de conhecimento sobre as coleções universitárias, acrescentando-Ihe valor (Medina, 2012).

As coleções do FEUPmuseu estão divididas em sete grupos disciplinares, correspondentes aos Departamentos e Serviços da FEUP: Engenharia Química, Informática, de Minas, Metalúrgica, Civil, Electrotécnica e Mecânica. Caracterizado como um museu de estrutura polinucleada, parte do seu acervo encontra-se exposto em grandes vitrinas e disperso entre os Departamentos, a Biblioteca e o hall central nos espaços de circulação, sem cumprir com uma narrativa expositiva. As vitrinas visam expor o acervo, criar visibilidade e aproximação com a comunidade FEUP (Medina, 2012).

O FEUPmuseu possui uma reserva no sexto andar da Biblioteca onde acolhe as atuais doações dos professores e académicos da FEUP. Segundo Medina (2020, citada em Bittencourt, 2020), este espaço, no futuro, abrigará um laboratório cujo objetivo será contemplar uma lógica de experimentação e exploração com atividades centradas nas coleções. Assim como outros serviços e departamentos da Faculdade, o FEUPmuseu utiliza também um espaço polivalente no piso zero da Biblioteca, cuja gestão é da competência do SDI, para a realização de atividades culturais e exposições temporárias. Como exemplo, cada dois anos, o FEUPmuseu estuda um núcleo de sua coleção e finaliza o estudo com uma exposição, neste espaço. Este espaço polivalente também é utilizado pela comunidade FEUP no desenvolvimento de exposições, divulgação de projetos de investigação, concurso de fotografia e projetos artísticos (Bittencourt, 2020).

Para a gestão do património, o FEUPmuseu utiliza o software chamado In Arte. O software possui várias funcionalidades, bem como uma base de dados com as fichas de inventário museológico. A base de dados é integrada num catálogo digital online e de livre acesso ao público. Logo, ele auxilia o acesso às coleções da FEUP, melhorando as atividades vinculadas à gestão de acervo e à investigação. $\mathrm{O}$ catálogo online espelha $\mathrm{O}$ 
caráter polinucleado do museu, como também, viabiliza o acesso em modo digital, mesmo nos horários que a FEUP não está aberta.

A estrutura polinucleado do FEUPmuseu atende a necessidade e objetivos de manter as coleções próximas dos seus departamentos de origem, de acordo com suas múltiplas valências: museológica, de ensino e investigação. Portanto, essa proximidade é imprescindível, de modo a incentivar os alunos a trabalhar com as coleções, a gerar novos conhecimentos e inspirar novas investigações (Medina, 2020, citada em Bittencourt, 2020). Paralelamente, preocupa-se em promover a história e a memória da comunidade académica da FEUP e a sua produção científica, de modo a inspirar e incentivar a comunidade FEUP à novas reflecções e projetos científicos. Assumindo um papel de mediador do património da faculdade em questão, o FEUPmuseu compreende que nem todos os membros da comunidade FEUP, e nem todos os seus visitantes são engenheiros. Logo, o FEUPmuseu procura trabalhar de maneira colaborativa, participativa e experimental, propondo, nas suas atividades e exposições, uma reflexão crítica contemporânea sobre a engenharia. Desta forma, define como um de seus principais desafios encontrar um modelo de museu universitário que atenda as necessidades de sua comunidade e visitantes.

Entre os modelos institucionais possíveis, o FEUPmuseu pretende apresentar-se como uma coleção visitável. Há duas preocupações centrais que fundamentam este seu objetivo. A primeira, a necessidade de estudar as suas as coleções, o que contribui para a compreensão e comunicação da importância dos objetos que as constituem como património da FEUP; a segunda preocupação é o desenvolvimento de "um percurso, um roteiro interno" que permita ligar todas as áreas expositivas do FEUPmuseu "de forma que um visitante interno e externo possa usufruir" a dimensão interpretativa do património (material e imaterial) da FEUP. Neste sentido, propõe uma nova adição a sua estrutura polinucleada e modelo institucional, i.e., a criação de um centro interpretativo, auxiliando, assim, a concretização de seu modelo de museu universitário (Medina, 2020, citada em Bittencourt, 2020). 


\section{Notas sobre centro interpretativo}

O centro interpretativo, enquanto ideia e espaço, surgiu ao fim do século XIX, nos Estados Unidos da América, com o objetivo de promover o património natural dos parques nacionais, preservar o ecossistema e transmitir a importância do seu valor patrimonial para os seus visitantes (sejam turistas ou comunidade). Segundo Izquierdo Tugas, Juan Tresserras e Matamala Mellin (2005) Tilden (1977) foi o primeiro académico a definir o que é um centro interpretativo. Com um olhar voltado para os parques nacionais americanos, o precursor autor constrói uma abordagem de um espaço de educação baseado na preservação da cultura patrimonial nacional:

\footnotetext{
An educational activity which aims to reveal meanings and relationships through the use of original objects, by firsthand experience, and by illustrative media, rather than simply to communicate factual information (Tilden, 1977, p. 8).
}

O mesmo autor defendia que, essencialmente, os centros interpretativos uniam dois fatores: o primeiro, interpretar o património que não é visível, isto é, a dimensão imaterial do património, demonstrar a sua importância e revelar o seu valor para um determinado público; o segundo, gerar curiosidade e enriquecer o conhecimento do mesmo, por meio da interpretação.

A conceção de centro interpretativo de Tilden (1977), está fundamentada em três vertentes: educação, património e natureza. Para o autor, a educação era a ferramenta interpretativa do património compreendido nos parques nacionais e, até os anos 1980, esses espaços estavam associados à promoção do turismo natural. Aos poucos, a associação ao ecoturismo tornou-se secundária e os centros interpretativos passaram a estar presentes nos meios urbanos e rurais (Izquierdo Tugas et al., 2005). Esta transformação ocorreu devido a alguns fatores, entre os quais, o facto de os centros interpretativos serem espaços que necessitam de poucos recursos financeiros 
para se manterem abertos, sendo uma solução face a necessidade de desenvolver o turismo e valorizar o património local (Pizarro, 2019).

Assim, a relação conceitual entre centro interpretativo e património natural foi-se perdendo, uma vez que a noção de território passou a ganhar força e a incorporar a sua definição. É neste território, onde se encontra o património, que deve ser protegido e salvaguardado. Desta forma, o centro interpretativo é o ponto de intersecção entre o discurso interpretativo do património de um determinado território que necessita ser preservado e a comunicação deste discurso à sociedade. Sendo assim, cada centro interpretativo desenvolve a sua essência e particularidades, seja com o objetivo de promover o turismo, um parque arqueológico, um sítio histórico ou até mesmo uma atividade identitária de uma comunidade (Izquierdo Tugas et al., 2005).

Os centros interpretativos possuem como objetivo educar e consciencializar os visitantes para a importância do património inserido num contexto territorial. $\mathrm{Na}$ maioria dos casos, as dimensões materiais e imateriais do património interpretado por estes espaços estão associadas às evidências culturais e/ou naturais. É bastante comum que os centros interpretativos façam uso de ferramentas de exposições criativas, como animações e apresentação em ecrãs, de modo a proporcionar ao visitante uma fácil leitura interpretativa do valor transmitido. Isto é, os centros interpretativos, fazem uso de ferramentas lúdicas para transmitir a importância cultural e identitário do património no território o qual está situado (Izquierdo Tugas, et al., 2005).

Para Binoy (2011), o centro interpretativo tem a função de transmitir e traduzir o património de maneira compreensiva para o público. Parte-se do princípio de que o visitante não percebe o valor do (cultural e identitário) do património, muito menos, a necessidade em preservá-lo e conservá-lo. Logo, é dever do centro interpretativo comunicar de forma a influenciar ou instruir a perceção do visitante. $\mathrm{O}$ autor completa explicando que os centros interpretativos podem ser associados a um museu ou serem 
independentes, a sua modalidade pode ser variada, assim como, há diversas formas de interpretação do património.

Alguns autores como Pizarro (2019), Chaumier e Jacobi (2008) discutem o limite entre museu e centro interpretativo. A fronteira entre ambos ainda não foi estabelecida e a discussão evidencia a necessidade de maiores estudos nesta área (Pizarro, 2019). Contudo, o museu e o centro interpretativo partilham características e, dado a isso, cria-se a ideia de que os dois são da mesma "família" (Chaumier \& Jacobi, 2008). Porém, os centros interpretativos não possuem a obrigatoriedade de constituir um acervo próprio, diferentemente dos museus (Bessard \& Robine, 2008). Inclusive, muitos centros interpretativos fazem uso de réplicas ou simplesmente não possuem acervo. Assim, o acervo não fundamenta a existência do centro interpretativo, e, sim, o seu âmbito territorial associado ao património a ser preservado (Pizarro, 2019).

Binoy (2011) procura justificar a diferença entre ambos pelas suas funções: enquanto os centros interpretativos são instituições especializadas em comunicar e interpretar o património imaterial, os museus têm por função recolher, conservar e estudar objetos. Já Pizarro (2019) aponta a diferença nas responsabilidades em ter um acervo. Segundo este autor, além das obrigações em manter o acervo preservado, o museu possui uma estrutura mais complexa do que a do centro interpretativo, de modo que necessita de mais recursos, financeiros ou humanos, para manter o seu funcionamento.

\section{Centro interpretativo e património universitário}

Durante muito tempo a ideia de património estava diretamente ligada à materialidade - monumentos, sítios, artefactos - e, consequentemente, a ideia de museu, à cultura material (Carvalho, 2009). No que diz respeito aos museus universitários, a literatura enfatiza esta ideia, uma vez que, historicamente, foram as coleções de objetos naturais e artificiais que constituíram os "gabinetes de curiosidade" e, depois, os museus. Contudo, a constituição do património é muito mais ampla, inclusive no contexto 
universitário. Vai além dos objetos e do espaço museológico, abrange monumentos, observatórios, laboratórios, bibliotecas, arquivos, e todos os produtos científicos associados à investigação e ensino, como livros, artigos, projetos e protótipos. Da mesma forma, engloba as tradições académicas e a identidade de uma comunidade (Lourenço, 2005). É considerado como um legado coletivo partilhado por uma comunidade (Lourenço \& Wilson, 2013, referido em Handfas, Granato, \& Lourenco, 2016).

Assim, a definição de património universitário é complexa e extremamente ampla. Abrange as dimensões tangíveis e intangíveis, materiais e imateriais, desde objetos que compõem uma coleção de ensino à produção científica associada a uma coleção; os jardins onde ocorrem pontos de encontro que promovem a socialização da comunidade, como também, as tradições culturais como a "praxe", ritual relacionado com a integração dos jovens que acabaram de chegar ao ensino superior. Em síntese, compreender o património universitário requer não só um olhar cuidadoso sobre as vertentes materiais e imateriais, mas, principalmente, a multidisciplinariedade que une a comunidade representada (Bittencourt, 2020).

Santos (1994) reflete que, no ato de preservar o património, o museu acaba por se apropriar do mesmo e explica que o museu contribui para a formação do cidadão em um "novo fazer cultural" (p. 91). Um ato estritamente ligado ao relacionamento entre museu e educação. A literatura aponta que as práticas museológicas envolvem um trabalho interdisciplinar e multidisciplinar que necessita da participação da comunidade do museu para que o mesmo se mantenha vivo e ativo. E o património cultural tem uma ação importante neste processo, ou seja, "é através da implementação de ações museológicas socialmente engajadas que o patrimônio cultural cumpre uma de suas funções primordiais: suscitar a criação de novos conhecimentos" (Figurelli, 2012, p. 53). O museu desempenha a função de mediador entre comunidade, património e território. É neste território onde ocorre a "construção, resinificação e apropriação das identidades" e do património envolvido pela comunidade (Figurelli, 2012). 
Alguns museus, em sua construção institucional, têm dificuldade em descentralizar a atenção na dimensão material do património. Quando assumem um trabalho com o território, património e comunidade, esta dificuldade tende a atenuar-se (Carvalho, 2009). Portanto, esta prática auxilia no desenvolvimento de outras narrativas expositivas e o desenvolvimento de atividades culturais associadas a estas dimensões.

E no caso dos museus universitários, a dimensão imaterial do património manifesta-se, como já citado, nas produções académicas, rituais universitários, cultura institucional, história universitária e científica. Já o território está associado ao local onde ocorrem estas manifestações. Por exemplo, a produção académica por diversas vezes ocorre no território universitário, em salas de aula e laboratórios. Por sua vez, o comprometimento com a comunidade está associado à produção de conhecimento e/ou atividades educativas executadas a partir do património universitário. Conclui-se, portanto, que as três vertentes que caracterizam o centro interpretativo - património imaterial, território e educação - vão ao encontro à essência dos museus universitários. Assim, em seu empreendimento para (re)definir a sua manifestação museológica, o FEUPmuseu planeia manter uma estrutura polinucleada com as coleções expostas nos seus respetivos departamentos de origem, atribuindo ao Centro Interpretativo o designo de existir como um espaço de encontro. Ou seja, para além de auxiliar na sua concretização enquanto uma coleção visitável, o FEUPmuseu pretende que o Centro Interpretativo seja um espaço que conjugue os diferentes núcleos de sua coleção por meio da interpretação do património da Faculdade; um espaço político e educacional responsável pela salvaguarda do património imaterial. Desta forma, o FEUPmuseu pretende tornar-se um agente de produção científica e um canal de diálogo entre a Faculdade e a sociedade por meio do património. Além disto, deseja contribuir para que a comunidade FEUP manifeste e participe ativamente na construção e representação da sua identidade. 


\section{Considerações finais}

Durante o estudo realizado para o desenvolvimento desta reflexão foi percetível a diversidade de modelos institucionais desempenhados pelos museus universitários, exemplificados aqui por tipologias identificadas através de uma breve análise dos museus da Universidade do Porto: coleções visitáveis, núcleo museológico, centro interpretativo, centro de documentação, galeria e gabinete de curiosidade.

Foi possível também compreender que, nas universidades, as práticas museológicas são definidas como um serviço à comunidade científica (Kozak, 2015), bem como, agentes de produção científica e mediadores de ideias. O museu universitário cuida do passado e do presente, da memória e da história de uma comunidade académica. Este cuidado resulta no desenvolvimento de novos conhecimentos científicos, no âmbito museológico e patrimonial. Paralelamente, o museu universitário preocupa-se em inspirar e incentivar a comunidade académica à novas reflecções e projetos científicos dentro da universidade (Bittencourt, 2020). Realizar os processos museológicos num espaço em que prevalece o novo é uma ação paradoxal. No entanto, são processos importantes para compreender o passado, divulgar a memória e auxiliar na construção de um futuro.

Assim, independente do modelo desempenhado, todo museu universitário necessita da união entre professores, investigadores, alunos, museólogos e a direção da universidade para ser constituído e a funcionar dentro da instituição. Em outras palavras, o funcionamento de um museu universitário depende da união transdisciplinar entre os campos da ciência investigativa e do ensino com a museologia.

No que diz respeito ao FEUPmuseu, uma das particularidades centrais do modelo pretendido é a intersecção entre o museu e o centro interpretativo. Território, educação e a dimensão imaterial do património são elementos comuns possíveis de serem observados nestes espaços, assim como, uma contínua transformação 
institucional por acompanharem as dinâmicas sociais de suas comunidades. Ou seja, os centros interpretativos estão enraizados em seu território, onde estabelecem um relacionamento com a sua comunidade por meio da identidade, e são pautados na preservação e comunicação de valores, memórias e do património (Bittencourt, 2020).

Neste sentido, o Centro Interpretativo do FEUPmuseu é pensado como um espaço de encontro, político e educacional que conjugará os diferentes núcleos do Museu por meio da interpretação do património da FEUP, de modo a contribuir para democratizar a memória institucional e comunicar as produções científicas da mesma, isto é, a dimensão imaterial do seu património.

Desta forma, o FEUPmuseu pretende tornar-se um agente de produção científica e um canal de diálogo entre a FEUP e a sociedade, por meio do património. Além disto, deseja ser um ponto de encontro que possibilite a comunidade FEUP manifestar e participar ativamente na sua identidade.

\section{Agradecimentos}

A autora expressa os seus agradecimentos à Prof. Doutora Elisa Noronha, pelo imenso suporte, paciência e dedicação, à coordenadora técnica do FEUPmuseu Susana Medina pela disponibilidade, incentivo e carinho, e a toda a equipa do SDI da FEUP pelo acolhimento e auxílio em múltiplas situações.

\section{Referências}

- Bessard, M., \& Robine, N. (2008). Les centres d'interprétation dans leur relation à la recherche et à la diffusion. La Lettre de l'OCIM. Musées, Patrimoine et Culture Scientifiques et Techniques, 119, 12-17. https://doi.org/10.4000/ocim.349 
- Binoy, A. T. (2011) Archaeological and heritage tourism interpretation: a study. South Asian Journal of Tourism and Heritage, 4(1), 101-107.

- Bittencourt, J. (2020). Centro Interpretativo do FEUPmuseu: Contributo para a sua Criação e para uma Política de Exposição. (Dissertação de Mestrado em Museologia, Universidade de Porto). Disponível em: https://repositorioaberto.up.pt/handle/10216/130231

- Carvalho, A. (2009). Os Museus e o Património Cultural Imaterial: Estratégias para o Desenvolvimento de Boas Práticas (Dissertação de Mestrado em Museologia, Universidade de Évora). Disponível em: https://www.researchgate.net/publication/296327495_Os_Museus_e_o_Patri monio_Cultural_Imaterial_Estrategias_para_o_Desenvolvimento_de_Boas_Pra ticas

- Chaumier, S., \& Jacobi, D. (2008). Nouveaux regards sur l'interprétation et les centres d'interprétation. La Lettre de l'OCIM. Musées, Patrimoine et Culture Scientifiques et Techniques, 119, 4-11. https://doi.org/10.4000/ocim.348

- Clercq, S. W., \& Lourenço, M. C. (2003). A globe is just another tool: understanding the role of objects in university. In UMAC (Ed.), University Museums and Collections. ICOM Study Series (Vol.11, pp. 4-6). Disponível em: https://icom.museum/wp-content/uploads/2018/07/11_ICOM-UMAC.pdf

- Council of Europe (2005). Recommendation of the Committee of Ministers to member states on the governance and management of university heritage (Adopted by the Committee of Ministers on 7 December 2005 at the 950th meeting of the Ministers' Deputies). Strasbourg, Council of Europe, European Union. Disponível em: https://wcd.coe.int/ViewDoc.jsp?id=1954741\&Site=CM

- Delicado, A. (2004, setembro 16-18). Para que servem os museus científicos? Funções e finalidades dos espaços de musealização da ciência [Paper presented]. VIII Congresso Luso-Afro-Brasileiro de Ciências Sociais, Coimbra, Portugal. Disponível em: https://www.ces.uc.pt/lab2004/pdfs/AnaDelicado.pdf

- Figurelli, G. R. (2012). Articulação entre educação e museologia. In G. R. Figurelli (Ed.), Cadernos de Sociomuseologia: O Público Esquecido pelo Serviço 
Educativo (Vol. 44, pp. 37-64). Lisboa: Universidade Lusófona. Disponível em: https://revistas.ulusofona.pt/index.php/cadernosociomuseologia/article/view/ 2872

- Gil, F. B. (2005). Museus Universitários: sua especificidade no âmbito da museologia. In A. Coelho \& A. Semedo (Coord.), Colecções de Ciências Físicas e Tecnológicas em Museus Universitários: Homenagem a Fernando Bragança Gil (pp. 33-54). Porto: Faculdade de Letras da Universidade do Porto - Secção de Museologia do Departamento de Ciências e Técnicas do Património. Disponível em: http://hdl.handle.net/10216/21193

- Handfas, E. R., Granato, M., \& Lourenco, M. C. (2016). O patrimônio cultural universitário de ciência e tecnologia: os acervos da Universidade Federal do Rio de Janeiro. Tendências da Pesquisa Brasileira em Ciência da Informação, 9(2). Disponível em: https://revistas.ancib.org/index.php/tpbci/article/view/405/405

- International Council of Museums [ICOM] (2007). ICOM Statutes, adopted by the $22^{\text {nd }}$ General Assembly in Vienna, Austria, on 24 August 2007. Disponível em: https://icom.museum/en/resources/standards-guidelines/museumdefinition/

- Izquierdo Tugas, P., Juan Tresserras, J., \& Matamala Mellin, J. C. (2005). Heritage Interpretation Centres: The Hicira Handbook. Barcelona, Espanha. Disponível em: https://www.diba.cat/c/document_library/get_file?uuid=63952a92-928c-4eb9a698-587bea5cf637\&groupld=99058

- Kozak, Z. (2007). Promoting the Past, Preserving the Future: British University Heritage Collections and Identity Marketing (PhD Thesis, University of St Andrews). Disponível em: http://hdl.handle.net/10023/408

- Lourenço, M. C. (2005). Entre Deux Mondes. La Spécificité et le Rôle Contemporain des Collections et Musées des Universités en Europe / Between Two Worlds: The Distinct Nature and Contemporary Significance of University Museums and Collections in Europe (Thèse de Doctorat, Histoire des Techniques, Muséologie, Conservatoire National des Arts et Métiers. École 
Doctorale Technologique et Professionelle. Paris). Disponível em: https://webpages.ciencias.ulisboa.pt/ mclourenco/chapters/MCL2005.pdf

- Lourenço, M. C., \& Dias, J. P. S. (2017) “Time Capsules” of Science: Museums, Collections, and Scientific Heritage in Portugal, ISIS v.108, no. 2 (pp.390-398). Disponível em: https://www.journals.uchicago.edu/doi/full/10.1086/692690

- Medina, S. (2012). Museus da Universidade do Porto: Diagnóstico. Documento não publicado. Porto: FEUP.

- Medina, S. (2014). Museu FEUP: estratégias e métodos para a gestão de produtos do conhecimento. In A. Semedo, E. N. Nascimento \& R. Centeno (Coords.), Atas do Seminário internacional O Futuro dos Museus Universitários em Perspetiva (pp. 123-132). Porto: Universidade do Porto. Disponível em: https://hdl.handle.net/10216/76434

- Pizarro, M. M. S. (2019). Centros interpretativos. In Direção Regional de Cultura do Norte - Ministério da Cultura (Ed.), Centros Interpretativos: Técnicas, Espaços, Conceitos e Discursos (Vol. 3, pp. 9-24). Disponível em: https://issuu.com/cultura.norte/docs/cole_o_patrim_nioanorte_n_3

- Santos, M. C. T. M. (1994). Documentação museológica, educação e cidadania. Cadernos de Sociomuseologia, 3(3), 79-92. Disponível em: https://revistas.ulusofona.pt/index.php/cadernosociomuseologia/article/view/ 308.

- Semedo, A. (2005). Que museus universitários de ciências físicas e tecnológicas? In A. Coelho \& A. Semedo (Coord.), Colecções de Ciências Físicas e Tecnológicas em Museus Universitários: Homenagem a Fernando Bragança Gil (pp. 265-281). Porto: Faculdade de Letras da Universidade do Porto - Secção de Museologia do Departamento de Ciências e Técnicas do Património. Disponível em: http://hdl.handle.net/10216/21193

- Taub, L. (2003). The history of science through academic collections. In UMAC (Ed.), University Museums and Collections. ICOM Study Series (Vol.11, pp. 14- 
16). Disponível em: https://icom.museum/wpcontent/uploads/2018/07/11_ICOM-UMAC.pdf\#page=14

- Theologi-Gouti, P. (2003). Le musée de sciences et techniques : archives de la recherche universitaire ouvertes aux différents publics. In UMAC (Ed.), University Museums and Collections. ICOM Study Series (Vol.11, pp. 12-13). Disponível em: https://icom.museum/wp-content/uploads/2018/07/11_ICOMUMAC.pdf

- Tilden, F. (1977). Interpreting our Heritage: Principles and Practices for Visitor Services in Parks, Museums, and Historic Places ( $3^{\text {rd }}$ ed). Chapel Hill, EUA: University of North Carolina Press.

- Wagensberg, J. (2005). O museu" total", uma ferramenta para a mudança social. História, Ciências, Saúde-Manguinhos, 12, 309-321. Disponível em: http://www.museudavida.fiocruz.br/4scwc/Texto\%20Provocativo\%20\%20Jorge\%20Wagensberg.pdf 


\section{Vanessa Sampaio Neves \\ vanessasampaioneves@gmail.com}

Museu Almeida Moreira: públicos e motivações de visita. 
Resumo

É objetivo deste texto contribuir para o

conhecimento geral dos públicos dos museus em

Portugal e, em concreto, do Museu Almeida Moreira, em Viseu.

Como forma de enquadramento do objeto de estudo, optou-se por uma abordagem inicial com foco na concetualização de estudos de públicos. $\mathrm{O}$ método de recolha de informação adotado foi o inquérito por questionário e entrevista, possibilitando caraterizar os visitantes do Museu Almeida Moreira quanto aos perfis sociodemográficos e compreender o contexto de visita, sobretudo, em termos das suas motivações. Os dados recolhidos demonstraram que os públicos do Museu Almeida Moreira são predominantemente femininos, jovens, com elevada qualificação escolar e com interesse em práticas culturais. Quanto às motivações, destaca-se a visita como meio de aprendizagem e descoberta, escapismo e interação social com amigos e/ ou família. Os visitantes procuram sobretudo experiências educativas, diversão ou interação social.

Palavras-chave: Públicos; Estudo de públicos; Motivações; Museu Almeida Moreira; Museologia

\section{Nota biográfica}

Vanessa Sampaio Neves é mestre em Museologia pela Faculdade de Letras da Universidade do Porto e licenciada em História pela mesma faculdade. Durante o $2^{\circ}$ ciclo de estudos, o Mestrado em Museologia, realizou uma dissertação focada nos públicos do Museu Almeida Moreira, instituição pertencente à Rede de Museus Municipais de Viseu. Atualmente é mediadora cultural do Museu do Benfica - Cosme Damião.

\section{Abstract}

The aim of this text is to contribute to the general knowledge of museum audiences in Portugal and, specifically, of the Almeida Moreira Museum, in Viseu. As a way of framing the object of study, an initial approach focused on the conceptualization of audiences and audience studies was chosen. The method of information collection adopted was the survey by questionnaire and interview, making it possible to characterize the Almeida Moreira Museum audience as to their sociodemographic profiles and understand the context of the visit, above all, in terms of their motivations. The data collected showed that Almeida Moreira Museum's audiences are predominantly female, young, with high educational qualifications and with an interest in cultural practices. As for their motivations, the visit stands out as a regular means of learning and discovery, escapism, and social interaction with friends and /or family. Above all, visitors are looking for educational, social, and pleasurable experiences.

Keywords: Audiences; Audience study; Motivations; Almeida Moreira Museum; Museology

\section{Biographical note}

Vanessa Sampaio Neves has a master's degree in Museology from the Faculty of Arts and Humanities of the University of Porto and a degree in History from the same faculty. During the $2^{\text {nd }}$ cycle of studies, the Masters in Museology, she carried out a dissertation on the audiences of the Almeida Moreira Museum, an institution that belongs to the Network of Municipal Museums in Viseu. She is currently cultural mediator at the Benfica Museum Cosme Damião 


\section{Introdução}

Este contributo é resultado da dissertação que se desenvolveu no âmbito do Mestrado de Museologia (MMUS) da Faculdade de Letras da Universidade do Porto (FLUP). O seu principal objetivo é o de contribuir para o conhecimento dos públicos dos museus em Portugal, mais em concreto, do Museu Almeida Moreira (MAM), instituição integrante da Rede de Museus Municipais de Viseu (RMMV).

No cenário atual da museologia, os estudos de públicos são vistos como uma importante ferramenta para a tomada de decisões dentro das instituições, permitindo o conhecimento e a compreensão dos utilizadores dos museus. As motivações são, de igual forma, um importante fator de estudo. Tal como Falk (2011) demonstra, perceber quem visita os museus e por que motivo o faz pode fornecer informações cruciais sobre o papel destas instituições na sociedade e na vida de cada pessoa, bem como os valores que transmitem e os benefícios da visita.

A Lei-Quadro dos Museus, em Portugal, evidencia a importância dos estudos de públicos, vincando a necessidade da sua realização: “O museu deve realizar periodicamente estudos de público e de avaliação em ordem a melhorar a qualidade do seu funcionamento e atender às necessidades dos visitantes" (Lei n.o 47/2004, p. 5386). Contudo, a sua concretização não tem sido uma prioridade, como acontece nos museus que integram a RMMV.

Apesar de alguns avanços - tendo como alguns exemplos o estudo de públicos dos museus nacionais, promovido pela Direção Geral do Património Cultural e o estudo desenvolvido por Semedo, Ganga e Oliveira (2018) - o contexto é ainda de pouco desenvolvimento na área em questão. Este estudo procura reforçar esta área, ainda em crescimento. Em primeiro lugar, para contribuir para o aumento da bibliografia, mas essencialmente, porque é necessário dotar os museus tutelados pela Câmara Municipal de Viseu (CMV) de uma ferramenta vital para a gestão das unidades museológicas. 
Assim sendo, este artigo procura aprofundar o conhecimento e atualizar as informações relativas ao público do MAM, no que concerne aos perfis sociodemográficos dos visitantes, o contexto de visita, mas sobretudo as motivações.

\section{Estudo de públicos}

A American Association of Museums (AAM) define estudo de públicos como o processo de obtenção de conhecimento sistemático de e sobre os visitantes de museus, atuais e potenciais, com o propósito de incrementar e utilizar disso conhecimento na planificação nas atividades relacionadas com o público (AAM, 1991, citada em Fernández, 2014, p. 11).

De acordo com Semedo et al. (2018), os estudos de públicos inserem-se num campo multidisciplinar de investigação científica, por vezes apelidado de estudo de públicos ou de avaliação de públicos, combinando métodos quantitativos e qualitativos, de modo a recolher informação sobre os visitantes e abrir espaços de avaliação e reflexão. As aplicações destes estudos são várias. Permitem o registo de informação sociodemográfica, hábitos de visita, preferências, e são essenciais para o desenvolvimento de exposições (facilitando decisões como idioma, tamanho da letra, vocabulário). São ainda fundamentais na gestão dos museus e nos serviços educativos (uma vez que se percebe quem é o público-alvo e podem adaptar-se as atividades a este), nomeadamente para decidir horas de abertura e fecho, preços, organização dos espaços, vigilância de salas, estratégias de comunicação. É uma autêntica ferramenta de gestão cultural que tem como finalidade alcançar um conhecimento científico e sistemático sobre os públicos dos museus.

Perante a grande versatilidade que demonstram, os estudos de públicos são vistos como um instrumento indispensável. Por isso, em Portugal têm sido realizados alguns trabalhos e investigações com vista ao conhecimento dos públicos de museus e monumentos nacionais. Não obstante, nos últimos anos, as análises de públicos têm sido desenvolvidas sobretudo em universidades, o que evidencia que dentro das 
instituições não se investe neste tipo de investigação, devido essencialmente à falta de recursos. Grande parte destes estudos são baseados em métodos quantitativos, maioritariamente através da aplicação de inquéritos por questionário aos visitantes. Verifica-se também que estes estudos, realizados no âmbito de dissertações de mestrado, provêm de várias áreas de estudo - Museologia, Sociologia, Turismo, Marketing, entre outras.

\subsection{Fatores motivacionais nos estudos de públicos}

É evidente que os museus procuram atrair públicos. Por isso, prontamente, se começou a tentar perceber quem visita os museus e por que motivo. Segundo Falk (2011), os visitantes estão no centro dos museus do século XXI e saber quem visita, porquê e para que fim, são questões de grande relevância, que importa serem estudadas e debatidas. Assim, as motivações de visita, quando bem compreendidas, são ferramentas que permitem dar a conhecer informações cruciais sobre o papel dos museus na sociedade e o valor que estes têm na vida de cada pessoa, bem como os valores que transmitem e os benefícios da visita.

De modo geral, os públicos de um museu são sempre caracterizados como heterogéneos na sua composição, compostos por pessoas de várias idades, origens, situações económicas e educativas. Apesar das características gerais, os públicos compõem-se por uma variedade de conjuntos que têm, cada um, uma motivação, um objetivo próprio e um comportamento específico. Desta forma, Falk (2006) defende que a visita a museus é algo muito complexo para ser entendido apenas com base em variáveis demográficas. Assim, só um estudo mais descritivo baseado nas motivações pode explicar de forma mais precisa esta experiência. Para o autor, estas questões são essenciais: "asking who visits the museum, why and to what end are not mere academic questions; they are questions of great importance" (Falk, 2011, p. 1.). A sua investigação tem como base o facto de serem poucos os trabalhos que procuram compreender a globalidade da experiência da visita - o antes, o durante e o depois sendo apenas realizados estudos sobre quem visita os museus, a frequência da visita 
ou os conjuntos sociais, o que, para Falk, não é suficiente. Tendo como questão base os motivos de visita, o referido autor fez centenas de entrevistas a visitantes de museus. Posteriormente, associou cada resposta à identidade dos indivíduos. Considerando que estas identidades são a confluência de forças sociais internas e externas - agências culturais e individuais, conclui que a experiência de cada visitante é uma síntese de motivações que se relacionam com a sua identidade e a forma como o museu é percecionado. Semedo et al. (2018) corroboram a ideia, considerando que "as necessidades e interesses dos visitantes estão relacionados com essas mesmas motivações" (p. 31). Assim e de acordo com Falk (2006; 2009), existem diferentes categorias de identidades relacionadas com as motivações dos visitantes:

Exploradores: visitantes com algum interesse no conteúdo dos museus, movidas pela curiosidade, que esperam encontrar alguma coisa que estimule o seu conhecimento; Facilitadores: visitantes com uma motivação social. A visita tem como foco possibilitar a experiência e a aprendizagem de outras pessoas do seu grupo social;

Colecionadores de experiências: visitantes que vão aos museus com o desejo de experimentar e conhecer novos locais que consideram um destino importante; Profissionais/amadores: visitantes que sentem uma estreita ligação entre o conteúdo do museu e as suas paixões profissionais ou passatempos. As visitas normalmente são motivadas pelo desejo de satisfazer um objetivo específico relacionado com a sua atividade;

Recarregadores de energia: visitantes que vão o museu motivadas pelo desejo de uma experiência contemplativa, espiritual.

O autor descreve, ainda, mais dois tipos de identidade: os peregrinos respeitosos, sendo estes os visitantes que vão a museus por um senso de dever ou obrigação de honrar a memória de quem está representado no espaço/instituição; e os exploradores de afinidades, um grupo que visita o museu que considera adequado às suas crenças pessoais ou personalidade. 
O estudo de Semedo et al. (2018) permitiu organizar as motivações de visita em quatro categorias:

- Aprendizagem e descoberta. Os visitantes procuram o museu para descobrir mais sobre um tema, ver algo novo, explorar novos lugares, expandir novos interesses, satisfazer a curiosidade, experimentar algo novo ou ainda obter autorrealização a partir da aprendizagem;

- Escapismo. Os visitantes procuram as instituições museais para fugir às responsabilidades quotidianas, porque procuram uma mudança agradável em relação às rotinas diárias, aliviar o stress e tensão, relaxar mentalmente, porque vão passear ou preencher o tempo livre e ainda, para fazer algo diferente;

- Interação social. Esta categoria inclui os visitantes que procuram passar tempo de qualidade com amigos/familiares, vivenciar algo com os amigos, levar a família/amigos aos museus, fazer alguma coisa com outras pessoas;

- Respeito e admiração/Autorrealização. Nesta categoria, inserem-se os visitantes que procuram aprovação social, procuram o sentido de identidade cultural, ter uma experiência/ligação com o passado, ou procurar um sentimento de pertença.

A conciliação de diversas metodologias no estudo de Semedo et al. (2018) permitiu um maior leque de resultados pormenorizados, garantindo uma perceção alargada sobre as motivações dos visitantes das instituições analisadas, para além de diversos outros dados, como informações sociodemográficas e sobre a experiência de visita.

Foram as categorias de Falk (2006; 2009) e as de Semedo et al. (2018) que foram utilizadas como modelos neste estudo. 


\section{Breve enquadramento institucional}

Uma vez que o estudo que se partilha se desenvolveu no MAM, importa contextualizar brevemente a instituição.

O MAM é um museu de história e arte situado no centro de Viseu, na rua Soar de Cima, na antiga habitação do Capitão Almeida Moreira, fundador do Museu Grão Vasco.

Integra a RMMV e constitui um valioso património concelhio, pois nele está exposta uma grande variedade de objetos de diversas tipologias, como documentos, mobiliário, armaria, pintura e gravuras, esculturas, etc. Trata-se de uma coleção bastante diversa, de grande abrangência cronológica, com objetos do século XVII ao XX. Segundo informação obtida junto da coordenadora do MAM, a coleção, em exposição e reserva, perfaz um total de 8896 objetos inventariados (número que pode sofrer alterações aquando da conclusão do processo de inventário, previsto para janeiro de 2021).

\section{Metodologia}

Perante os objetivos enunciados anteriormente, as opções metodológicas tomadas ao longo deste estudo decorreram das dimensões de análise consideradas e foram, por isso, seguidas diferentes estratégias. Primeiramente optou-se por uma consulta de fontes documentais e bibliográficas. Para a obtenção de dados dos próprios visitantes foi utilizada uma metodologia mista, optando-se pela realização de inquérito por questionário, para obter informações sociodemográficas, e uma entrevista semiestruturada, para informação sobre as motivações.

Relativamente à amostra foram considerados todos os visitantes, maiores de idade, que entraram no MAM e que aceitaram participar no estudo. A aplicação decorreu desde finais de janeiro de 2020 até ao último dia do mês de fevereiro do mesmo ano. No total o inquérito foi aplicado de forma descontinuada durante 20 dias. Quanto ao horário, nos dias úteis, no período da manhã, foram aplicados os inquéritos entre as 
$10 \mathrm{~h} 00$ e as $13 \mathrm{~h} 00$ e, no período da tarde, entre as $14 \mathrm{~h} 00$ e as $17 \mathrm{~h} 30$, ao passo que nos dias de fim de semana a aplicação foi feita no período da tarde entre as $14 \mathrm{~h} 00$ e as 17.30h.

Do estudo resultou um conjunto de dados qualitativos e quantitativos que permitiram retirar as conclusões para este estudo.

As entrevistas foram realizadas com base num guião estabelecido com perguntas e temas a desenvolver, mas a resposta foi livre e aberta, deixando espaço para o desenvolvimento de um diálogo natural entre o visitante e o entrevistador. $\mathrm{O}$ questionário foi construído em língua portuguesa, espanhola e inglesa. O tempo estimado para o seu preenchimento não ultrapassou os 5 minutos. Quanto ao seu conteúdo foi composto por um conjunto de dez perguntas (1. Idade; 2. Género; 3. Nacionalidade; 4. Local de residência; 5 . Nível de escolaridade; 6 . Área de formação; 7. Profissão; 8. Condição perante o trabalho; 9. Número de membros do agregado familiar; 10. (facultativa) E-mail para investigações futuras). Combinava perguntas fechadas e abertas.

Na totalidade foram realizadas 36 entrevistas e 60 questionários (por vezes as entrevistas eram realizadas a mais que um visitante e, desta forma, há mais questionários do que entrevistas). As entrevistas duraram cerca de 5 a 10 minutos e tiveram lugar numa sala de apoio junto à receção do museu.

Por fim, procedeu-se à análise das entrevistas e questionários com o apoio do software Nvivo e do Excel.

\section{Resultados. Análise e discussão}

\subsection{Dados sociodemográficos}

Relativamente aos resultados, verifica-se que, no que diz respeito:

- Ao género, os visitantes são, maioritariamente, do género feminino, representando $58,3 \%$, relativamente a $41,7 \%$ do sexo masculino; 
- À idade, o escalão etário entre os 26 e os 35 anos é o que mais se destaca, seguido do escalão dos 56 aos 65 anos. Os visitantes inquiridos têm uma média de idades de 45 anos;

- À coabitação, a maioria dos visitantes do museu vive em família (83\% dos visitantes); - À nacionalidade, 88,3\% (53 dos 60 visitantes) dos visitantes é de nacionalidade portuguesa, representado mais de $3 / 4$ da amostra. Os visitantes estrangeiros foram apenas sete (quatro vindos do Brasil, dois de Espanha e um da China-Macau);

- À proximidade geográfica relativamente à morada do MAM, cerca de $40 \%$ reside no distrito de Viseu (23 dos 60 inquiridos). A proximidade geográfica corresponde, desta forma, a um importante fator de captação de públicos. Não obstante, verifica-se uma considerável mobilização de outras zonas, essencialmente de Lisboa, cujos visitantes nele residentes representam 20\% (12 dos 60 visitantes). Residuais são as restantes regiões de Portugal Continental Braga (6,7\% - 4 visitantes), Porto (5\% - visitantes), Aveiro, Coimbra e Leiria com 3,3\% (2 visitantes de cada um dos distritos). Com apenas um visitante de amostra pode referir-se Castelo Branco, Guarda, Bragança, Santarém e Setúbal, representando individualmente $1,6 \%$ da amostra;

- Ao nível de escolaridade. Trata-se de um importante indicador, pois, tal como afirmam Bourdieu e Darbel (2003), a frequência de visita nos museus de arte está relacionada com a escolaridade. As principais conclusões das premissas destes autores seguem a ideia de que a frequência nos museus aumenta à medida que a instrução também se intensifica. Neste caso, verifica-se uma elevada qualificação escolar sendo que $75 \%$ dos visitantes têm formação superior (43,3\% licenciados, 18,3\% com mestrado, $10 \%$ pós-graduados e 3,3\% doutorados). Também se pode inferir, com base nos inquéritos realizados, que apenas $5 \%$ têm escolaridade até ao 3. ciclo do ensino básico. A restante percentagem (19\%) diz respeito aos visitantes que completaram o 12. ano de escolaridade; 
- Às áreas de formação, são bastante diversas. Não obstante, há algumas que se destacam, nomeadamente história e arquitetura, ambas com seis referências. Cinco dos inquiridos indicaram áreas de formação relacionadas com saúde.

De forma conclusiva, pode verificar-se uma predominância (apesar de não ser muito vincada) de um público feminino. As idades dos visitantes revelam um público sobretudo jovem/adulto e com elevada escolaridade. Os visitantes têm um nível de instrução superior, mostrando a existência de uma relação entre o nível de escolaridade e a frequência de equipamentos e de práticas culturais, tal como anteriormente foi apontado. A maior parte dos visitantes desempenha uma profissão, sendo que o grupo ocupacional que se destaca é o das profissões intelectuais e científicas. É um público profissionalmente ativo, especialista das atividades intelectuais e científicas e é constituído sobretudo por professores, arquitetos e profissionais da área de saúde. Estes dados são comuns em vários estudos de públicos consultados - é comum a todos a elevada qualificação escolar e profissional, comprovando que o consumo cultural ainda não é de igual modo acessível a todas as classes sociais. Comprova também a forte relação entre a frequência da visita a museus e o nível de estudos dos visitantes, conforme Bourdieu e Darbel (2003) defendiam.

\subsection{Motivações}

Neste estudo procurou-se perceber as motivações dos visitantes do MAM. Para concretizar este objetivo foi colocada no início de cada entrevista a mesma questão aos inquiridos, sendo esta a pergunta que desencadeava a restante conversa: "O que o motivou a vir aqui hoje?" ou "Porque veio aqui hoje?".

A partir desta pergunta as respostas foram variadas. No entanto, convergiram em torno de quatro dimensões: passeio com a família; conhecer a cidade; conhecer ou rever a exposição permanente e/ou temporária; e a interação com os amigos ou 
família. Foram estes os motivos de visita mais apontados pelos visitantes entrevistados.

Verificou-se que o passeio, as férias em família, descobrir mais sobre o museu e a história de Viseu, levar familiares a conhecer o MAM, bem como a descoberta da exposição permanente e temporária foram as respostas mais dadas pelos visitantes, enquadrando-se, portanto, nas categorias Exploradores e Facilitadores, propostas por Falk (2006, 2009), e Aprendizagem e descoberta, Escapismo e Interação Social, desenvolvidas por Semedo et al. (2018).

Desta forma, percebe-se que, independentemente dos vários fatores sociodemográficos anteriormente enunciados, como a idade, género, profissão, escolaridade, ou outro, a maioria dos visitantes apontou como grande motivação de visita ao MAM, o conhecer novos espaços e a exposição temporária e/ou permanente, desenvolver e ampliar conhecimentos, descobrir, pensar. Nesta categoria (Aprendizagem e descoberta/ Exploradores) inserem-se 61,7\% da amostra.

De seguida aparece-nos a motivação denominada de Escapismo. Da amostra, 20\% afirma que a ida ao MAM se insere num percurso de férias/ passeio/ turismo pela cidade de Viseu, onde a visita a museus faz parte deste mesmo percurso, sendo a visita planeada ou meramente ocasional.

Tal como no estudo de Semedo et al. (2018), a interação social assumiu uma importância notória. Dos inquiridos no MAM, 8,3\% responderam que a motivação principal da visita se relacionou com a interação social ou familiar. Dar a conhecer o MAM aos familiares e amigos foi um dos motivos mais apontados.

$5 \%$ dos inquiridos deslocaram-se ao museu uma vez que consideraram que a exposição permanente ou temporária se relacionava com a sua identidade pessoal ou local, sendo que se sentem ligados, de certa forma, aos temas desenvolvidos, procurando um sentimento de pertença.

Um visitante (1,7\% da amostra) aponta que decidiu ir ao MAM pela sua ligação profissional aos museus, mostrando imprescindível os retornos esporádicos a este tipo 
de instituições e outro afirmou que só foi ao museu para comprar um postal para oferecer à mulher.

Em síntese, a análise e interpretação das entrevistas permitiu concluir que as motivações para a visita ao MAM podem ser organizadas em redor de quatro categorias: Explorador/Aprendizagem e Descoberta; Escapismo; Interação Social/Facilitadores e, Respeito e Autorrealização/Colecionadores de experiências. As propostas assentam na premissa de que os visitantes se deslocam ao museu para descobrir mais sobre a instituição, para desenvolverem conhecimento sobre algum tema, porque têm curiosidade em descobrir algo novo. Neste caso as respostas mais frequentes foram a curiosidade e tentativa de descoberta de algo novo, diferente ou enriquecedor sobre o acervo do MAM, pela exposição temporária ou ainda o interesse mais específico sobre um núcleo em concreto, como mobiliário, pintura ou cerâmica, por exemplo. Logo de seguida aparece a categoria apresentada por Semedo et al. (2018), como o Escapismo, em que os visitantes afirmam que vão visitar o museu como consequência do passeio pela cidade de Viseu. A Interação Social ou a identidade Facilitadores surge de seguida, com $8 \%$ da amostra, evidenciando que há uma tentativa de levar os amigos ou familiares ao museu, procurando uma aprendizagem comum, ou ainda a realização de um programa conjunto com os familiares.

\subsection{Contexto de visita}

Para além das informações sobre as motivações, as entrevistas permitiram ainda recolher uma série de dados sobre a experiência de visita, desde como os visitantes conheceram o museu, à forma de acompanhamento, às aprendizagens adquiridas, bem como os hábitos de visita a instituições culturais, dados estes que se explanam de seguida.

Sobre a forma como conheceram o museu, percebe-se que a internet e o posto de turismo são os meios de informação por excelência. Ainda se pode concluir que os visitantes preferem visitar o museu acompanhados (cerca de $3 / 4$ dos visitantes). 
Relativamente aos pontos fortes da instituição, os visitantes destacam a apresentação e organização da exposição, o estado de conservação das peças expostas, a realização de exposições temporárias com alguma regularidade e o acolhimento por parte do pessoal. O único ponto negativo apontado foi a falta de divulgação da instituição. A maioria dos visitantes afirma que voltaria ao MAM, tendência que pode demonstrar que estes ficaram satisfeitos com a instituição e interessados no conteúdo das exposições. A maior parte dos visitantes é estreante no museu, mas afirma que tem por hábito visitar instituições culturais, essencialmente em período de férias ou em turismo.

\section{Considerações finais}

Nos últimos anos, de acordo com dados recolhidos no portal do Instituto Nacional de Estatística (INE, 2020), os públicos dos museus em Portugal têm aumentado exponencialmente. De igual modo, no MAM, verifica-se um crescimento, ao longo dos anos, no número de visitantes. Como consequência, surgem novos desafios, tais como a necessidade de criar atividades capazes de atrair novos públicos e de fidelizar os que já frequentam. Por isso, torna-se fulcral conhecer os públicos que frequentam as instituições culturais. O MAM não pode, nem deve, ser uma exceção.

Para além destas questões, é importante apontar que, no atual panorama museológico, os estudos de públicos estão sucessivamente a ser valorizados perante a importância que revelam em termos sociais, económicos e institucionais. Os públicos estão cada vez mais críticos, seletivos e exigentes, visto que a oferta cultural é mais diversificada e atrativa. Perceber as motivações, necessidades e expectativas dos visitantes dos museus torna-se essencial, uma vez que estes são vistos como cruciais para a conceção de programas ou projetos. O objetivo do estudo que se partilhou foi perceber quem são os públicos do MAM e por que motivo visitam esta instituição. Sobre os pontos mencionados, é necessário refletir no que o MAM pode aplicar no seu dia a dia. Os museus desempenham um papel fundamental na sociedade e é-lhes 
pedida uma aproximação paulatina aos seus públicos e não-públicos, através de um conjunto de meios de comunicação. São estes meios que o MAM deve desenvolver. As redes sociais são cruciais num mundo cada vez mais informatizado. $\mathrm{O}$ online veio permitir uma maior facilidade e rapidez em trocar ideias, conhecimentos, informações. Tornar as redes sociais mais atrativas permitiria ao MAM elucidar os seus públicos, fidelizar os seus visitantes e "convidar" quem não conhece, a visitar a instituição. Este estudo permitiu a perceção de que muitos visitantes procuram novos locais para conhecer, para fomentar conhecimentos previamente adquiridos e para conviver com a família e amigos. Obter informação através da internet torna o processo mais simples e atrativo. O desenvolvimento de um website próprio, sem depender da tutela da CMV, mostrar-se-ia primordial. Este, poderia ter informação sobre a coleção, espaços e horários, por exemplo. A dinamização da página do Facebook e Instagram, através da partilha de fotografias, pequenos vídeos e textos que acompanham as imagens publicadas, seria igualmente outra solução, permitindo, assim, um envolvimento dos públicos mais constante. As ferramentas online são também essenciais para o contacto direto com os públicos, permitindo aos utilizadores uma maior interação com a instituição. Conhecer o público-alvo é já uma maneira de adotar uma estratégia adequada a estes.

Os resultados sociodemográficos mostram a necessidade de planificar exposições que atraia um público que até ao momento do estudo, o MAM não conseguiu atrair, nomeadamente pessoas com baixo nível de instrução e estrangeiros. A exposição patente no MAM “Beira Ilustre”, da artista local Rosário Pinheiro, aquando da realização do estudo, foi um passo em frente nesse sentido. Foram vários os visitantes entrevistados que se sentiram ligados à exposição ou pelo tema ligado ao distrito de Viseu (essencialmente pessoas idosas), ou pelo facto de serem retratos bastante apelativos (de um público mais jovem e das pessoas com menos formação académica).

O desenvolvimento de eventos, como concertos, recitais de poesia, ou outros, seria, de igual modo, outro meio de dinamizar a instituição, torná-la mais atrativa para quem já a frequenta e, para quem não a conhece, um primeiro contacto interessante. 
Sobre os visitantes atuais e quanto às suas motivações, ficou confirmado que a Aprendizagem/Descoberta e a Interação Social, são os motivos que mais levam visitantes ao museu. Esta é uma importante pista para a definição de estratégias de formação e comunicação com os públicos. Uma vez que se comprova que muitos dos visitantes não têm conhecimentos na área da arte e que vão com o objetivo de aprender ou ensinar, é importante que o MAM mantenha sempre presente a sua faceta educativa. Uma sugestão que se apresenta é a disponibilização de textos com uma linguagem mais simplificada e adaptados a grupos familiares e/ou para os mais jovens e, mesmo que pareça utópico, a adoção de visitas orientadas de acordo com os conhecimentos e interesses dos visitantes.

Perceber as motivações é perceber os visitantes, as suas necessidades e expectativas. Entender as características dos públicos e do que os move, torna possível atender às necessidades de mais visitantes ao mesmo tempo. Entender as motivações é entender a natureza da experiência de visita e permite melhorá-la, tornando-a mais atraente, satisfatória e memorável. Um público mais satisfeito é um público que regressa e que recomenda a instituição.

\section{Agradecimentos}

Um agradecimento em especial à orientadora da dissertação, Professora Doutora Alice Semedo. Também ao Museu Almeida Moreira, em especial à coordenadora do Museu e colega Sandra Alves pelo acompanhamento dado.

\section{Referências}

- Bourdieu, P. \& Darbel, A. (2003). O Amor pela Arte. Os Museus de Arte na Europa e seu Público. São Paulo: USP/ EDUSP.

- Falk, J. (2006). Understanding Museum Visitors'Motivations and Learning. Disponível em: https://slks.dk/fileadmin/user_upload/dokumenter/KS/institutioner/museer/In 
dsatsomraader/Brugerundersoegelse/Artikler/John_Falk_Understanding_muse um_visitors_motivations_and_learning.pdf

- Falk, J. (2009). Identity and the Museum Visitor Experience. Walnut Creek: Left Coast Press.

- Falk, J. (2012). The museum visitor experience: Who visits, why and to what effect? In G. Anderson (Ed.). Reinventing the Museum: The Evolving Conversation on the Paradigm Shift, Second Edition, pp. 317-329. Lanham, MD: AltaMira Press.

- Fernández, J. M. (2014). Iniciación a los Estudios de Visitantes en Museos. Saarbrücken: Publicia.

- Instituto Nacional de Estatística [INE] (2020). Visitantes (N.o) de museus por Tipologia. Disponível em:

https://www.ine.pt/xportal/xmain?xpid=INE\&xpgid=ine_indicadores\&contecto $=$ pi\&indOcorrCod=0007519\&selTab=tab0\&xlang=pt

- Lei no 47/2004. Lei-Quadro dos Museus Portugueses (2004). Diário da República n.o 195/2004, Série l-A de 19 de Agosto de 2004, 5379-5394. Disponível em: https://dre.pt/dre/detalhe/lei/47-2004-480516

- Semedo, A., Ganga, R., \& Oliveira, C. (2018). Visitar Museus e Monumentos: um Estudo Piloto de Fatores Motivacionais. Porto: CITCEM. 


\section{Louise Palma}

louisepalma@gmail.com

Avaliação diagnóstica de serviços educativos: alguns resultados do caso da Rede de Museus de Vila Nova de Famalicão. 
Resumo

Este texto apresenta os principais resultados do relatório de estágio, defendido na conclusão do Mestrado em Museologia, com orientação de Alice Semedo e coorientação de Liliana Aguiar. O objetivo foi aplicar uma abordagem de avaliação diagnóstica no mapeamento das atividades propostas pelo serviço educativo das unidades museológicas da Rede de Museus de Vila Nova de Famalicão. Para tal, foi utilizado um desenho de métodos mistos simultâneos com traços de um desenho etnográfico. Os dados foram recolhidos através de um inquérito online e uma ficha de diagnóstico, com o objetivo de traçar o perfil dos colaboradores, relacionar o serviço educativo dos museus e as suas equipas, e mapear as atividades planeadas para o ano de 2019. A análise realizada mostra que, ao ser aplicada na esfera do serviço educativo, a avaliação se apresenta como um método útil e relevante para conhecer práticas, servindo de ponto de partida para mudanças mais profundas.

Palavras-chave: Avaliação; Educação em museus; Avaliação em museus; Rede de museus

\section{Nota biográfica}

Louise Palma é Mestre em Museologia pela FLUP, desde 2020. Atualmente, integra a equipa da Rede de Museus de Vila Nova de Famalicão. Ao longo do percurso académico, explorou temáticas em torno da educação em museus e da arte contemporânea, tendo desenvolvido práticas nos serviços educativos da Casa São Roque - Centro de Arte Contemporânea e da Casa da Arquitetura. Em 2018 concluiu o curso de Mestrado em História da Arte, Património e Cultura Visual, também na FLUP. Entre 2011 e 2017, atuou como jornalista no Rio de Janeiro.

\section{Abstract}

This paper showcases the key results from the internship report, defended at the conclusion of the master's degree in Museology, oriented by Alice Semedo and co-oriented by Liliana Aguiar. The objective was to apply a diagnostic evaluation approach to map the activities proposed by the educational programmes of Museum Network of Vila Nova de Famalicão. For this, a simultaneous mixed methods design with traces of an ethnographic design was used. The data was collected through an online survey and a diagnostic form, with the objective of tracing a profile of employees, defining a relationship between the educational programmes of museums and their teams, and mapping the educational activities planned for 2019. The data analysis shows that, when applied in the context of the educational programming, the evaluation presents itself as a useful and relevant method to understand practices and as a starting point for deeper changes.

Key words: Evaluation; Education in museums; Evaluation in museums; Network of museums

\section{Biographical note}

Louise Palma has a master's degree in Museology from FLUP, since 2020. works at the Museum Network of Vila Nova de Famalicão. Her academic career explores themes related to education in museums and contemporary art, and those studies that have been put to practice in educational programmes in institutions such as Casa São Roque Centro de Arte Contemporânea and Casa da Arquitetura. In 2018, she also completed the master's course in Art History, Heritage and Visual Culture, at FLUP. Between 2011 and 2017, she worked as a journalist in Rio de Janeiro. 


\section{Introdução}

Este contributo partilha os principais resultados do relatório de estágio apresentado como conclusão do Mestrado em Museologia (MMUS) na Faculdade de Letras da Universidade do Porto (FLUP), em Vilela (2020), com orientação de Alice Semedo e coorientação de Liliana Aguiar. O trabalho teve como principal objetivo aplicar uma abordagem de avaliação diagnóstica no mapeamento das atividades propostas pelo serviço educativo das unidades museológicas da Rede de Museus de Vila Nova de Famalicão (RMVNF).

Avaliar é uma prática inerente ao ser humano, uma vez que é um ato comum e quotidiano de determinar o valor de algo. No entanto, ao ser desenvolvida como prática profissional e disciplinar, a avaliação caracteriza-se como um processo sistemático (Stufflebeam \& Coryn, 2014).

No campo dos museus, a avaliação é geralmente aplicada para conhecer os perfis de público, comprovar os resultados de programas educativos (Pérez Santos, 2000), medir o impacto de exposições e apoiar a prestação de contas (Korn, 1989). No entanto, o campo disciplinar apresenta diversas abordagens de avaliação, que podem e devem ser aplicadas em museus como prática recorrente.

Importa ter em conta que a metodologia de avaliação é realizada com objetivos que a diferem da investigação, por exemplo, tendo funções específicas e métodos próprios (Mertens \& Wilson, 2018; Stufflebeam \& Coryn, 2014). Outra característica do campo são as normas-padrão ${ }^{1}$, que oferecem uma orientação oficial para a realização de ações de avaliação. $\mathrm{O}$ avaliador, por sua vez, é figura central no processo, ao assumir um conjunto de premissas filosóficas - chamado de paradigma por alguns autores (Mertens \& Wilson, 2018; Denzin \& Lincoln, 2005; Guba, 1990) - que reflete na

1 Corresponde à tradução livre, feita pela autora, do termo standards, que é usado por Mertens e Wilson (2018, p. 25) para referir-se ao "The Program Evaluation Standards", publicado pelo JCSEE em 2010. Stufflebeam e Coryn (2014, p. 70) utilizam o termo para referir-se também ao "Guiding Principles for Evaluators", publicado pela AEA, e ao "Government Auditing Standards", publicado pelo U.S. Government Accountability Office. 
avaliação a sua própria visão de mundo e está relacionado com conceitos e possíveis abordagens da avaliação.

A avaliação diagnóstica apresenta-se como um método ainda pouco explorado no contexto museológico e, consequentemente, pouco debatido na Museologia. Neste sentido, o presente trabalho teve como principal objetivo aplicar uma abordagem de avaliação diagnóstica para o mapeamento das atividades propostas pelo serviço educativo das unidades museológicas da RMVNF - instituição onde foi realizado o estágio curricular no âmbito do MMUS.

No contexto da programação do serviço educativo, advoga-se que tal método pode ser usado como ferramenta para ver o sistema como um todo, sendo, então, considerado o primeiro passo para uma mudança de pensamento relativamente à programação.

A proposta de explorar a avaliação de serviços educativos parte da carência notória de estudos no campo da avaliação, principalmente em Portugal, e também se justifica com a necessidade da instituição em perceber o que vinha sendo feito em termos de serviço educativo, como ponto de partida para a elaboração de uma política de educação.

\section{Pensar e trabalhar na prática: o projeto na RMVNF}

A RMVNF é uma organização reticular que reúne, atualmente, 10 museus - Casa de Camilo - Museu. Centro de Estudos (CC), Museu Bernardino Machado (MBM), Museu Fundação Cupertino de Miranda - Centro Português do Surrealismo (FCM), Museu Nacional Ferroviário - Núcleo de Lousado (MNF-NL), Museu da Indústria Têxtil da Bacia do Ave (MIT), Museu de Cerâmica Artística da Fundação Castro Alves (FCA), Museu do Automóvel (MA), Museu da Guerra Colonial (MGC), Casa-Museu Soledade Malvar (CMSM), Museu de Arte Sacra da Capela da Lapa (MASCL) - e duas coleções visitáveis

- Museu da Confraria da Nossa Senhora do Carmo de Lemenhe (MCNSCL) e Museu Cívico e Religioso de Mouquim (MCRM). 
Desde a sua formação, em 2012, a RMVNF atua como uma zona de intersecção entre essas 12 unidades museológicas, servindo-Ihes de apoio e promovendo a dinamização através de uma série de atividades. Tendo tutelas, níveis de gestão e tipologias de coleções diferentes, tais instituições partilham entre si o mesmo território, mas mantêm uma programação independente, no que diz respeito a atividades educativas. Em 2018, foi proposta uma mudança de paradigma na RMVNF, relativamente à sua atuação na comunidade, através da reformulação e posterior afirmação de serviços como o serviço educativo (Rede de Museus de Vila Nova de Famalicão, 2019).

Entende-se que a avaliação diagnóstica desenvolvida no âmbito do estágio curricular apresenta-se como um contributo neste processo de reflexão ${ }^{2}$ e mudança sobre o papel desempenhado por cada instituição, a sua missão e os desafios enfrentados no território em que está inserida.

Acredita-se que, ao entender as partes, é possível identificar pontos fortes e fracos do sistema como um todo, capazes de basear estratégias futuras para um trabalho em rede a nível do serviço educativo.

\section{Metodologia}

Os objetivos gerais do estudo foram traçados para responder a questões que orientaram o seu desenvolvimento. A primeira, em torno do papel da avaliação diagnóstica na melhoria do serviço educativo e na articulação, no contexto de uma rede de museus. Depois, questionou-se sobre o que era feito em termos de serviço educativo na RMVNF e qual era o perfil dos mediadores que atuam nessas unidades museológicas. Por fim, sobre como o serviço educativo desses museus se articula ou pode se articular entre eles e a própria rede.

2 Com a coordenação científica de Alice Semedo, o processo teve início em novembro de 2018 com a realização workshop Ser/Fazer Museu e resultou na realização do vídeo "O museu é um lugar de..." e na publicação "Definir a missão... da necessidade ao desafio", disponibilizada no formato físico e digital em novembro de 2019 (Rede de Museus de Vila Nova de Famalicão, 2019b). 
Transitando entre modelos e abordagens encontrados na revisão da literatura especializada (Vilela, 2020), a avaliação diagnóstica inspirou-se no Paradigma Transformador (Mertens, 2009; Mertens \& Wilson, 2018), em que o avaliador assume a justiça social como princípio de orientação do trabalho, procurando inspirar a mudança de atitude. Optou-se por um desenho de métodos mistos simultâneos na recolha simultânea dos dados quantitativos e qualitativos, com traços de um desenho etnográfico (Creswell, 2014), que se relaciona com o foco nas experiências pessoais, nas atividades diárias e no contexto social do quotidiano, a partir da perspetiva dos participantes.

Propôs-se ainda um desenho cíclico, que sugere a avaliação como um processo contínuo. Ao retornar para o início do ciclo, o resultado de uma avaliação alimenta os seus participantes com informações relevantes que os ajudam nas tomadas de decisão e os inspiram nas mudanças de pensamentos e atitudes (Mertens \& Wilson, 2018).

Na primeira fase do trabalho, dedicada à compreensão das particularidades da avaliação como metodologia de pesquisa, foi definida a amostra - que incluiu as 10 unidades museológicas da Rede que têm serviço educativo.

Na segunda fase, foram criados os instrumentos de recolha de dados, que buscavam alcançar os seguintes objetivos específicos: mapear o que, quando, por quem e quais os recursos utilizados na realização das atividades do serviço educativo dos museus da RMVNF; traçar um perfil sociodemográfico dos mediadores dos museus da RMVNF; perceber potencialidades, oportunidades, fraquezas e vulnerabilidades no âmbito do serviço educativo; e procurar a mudança de pensamento e atitudes, inspirando ações neste sentido.

Para levantar os dados relativos às atividades, foi desenvolvida uma ficha de diagnóstico, a partir da ficha de levantamento de atividades utilizada pelo Observatório de Educación Patrimonial en España (OEPE) e adaptada no âmbito das atividades da Unidade Curricular "Políticas e Práticas de Comunicação em Museus" (Ornellas, Palma \& Sbragio, 2018). E, para traçar o perfil sociodemográfico dos colaboradores, responsáveis pela elaboração e/ou execução das atividades de serviço 
educativo mapeadas pelo estudo, foi desenvolvido um inquérito online. Aplicadas através da ferramenta Google Forms, as 15 questões tinham o objetivo de recolher informações gerais deste grupo de pessoas que desempenham funções semelhantes para tentar, a partir daí, entender de que forma elas partilham, ou não, competências em termos de formação profissional e de experiência de vida.

Nessa fase também se deu uma aproximação com as equipas de trabalho, que foi importante para que os profissionais entendessem a relevância da avaliação como algo coletivo. Neste processo, foi possível acompanhar algumas das atividades realizadas pelo serviço educativo dos museus, cujas impressões foram apontadas num diário de bordo (Fig. 1).

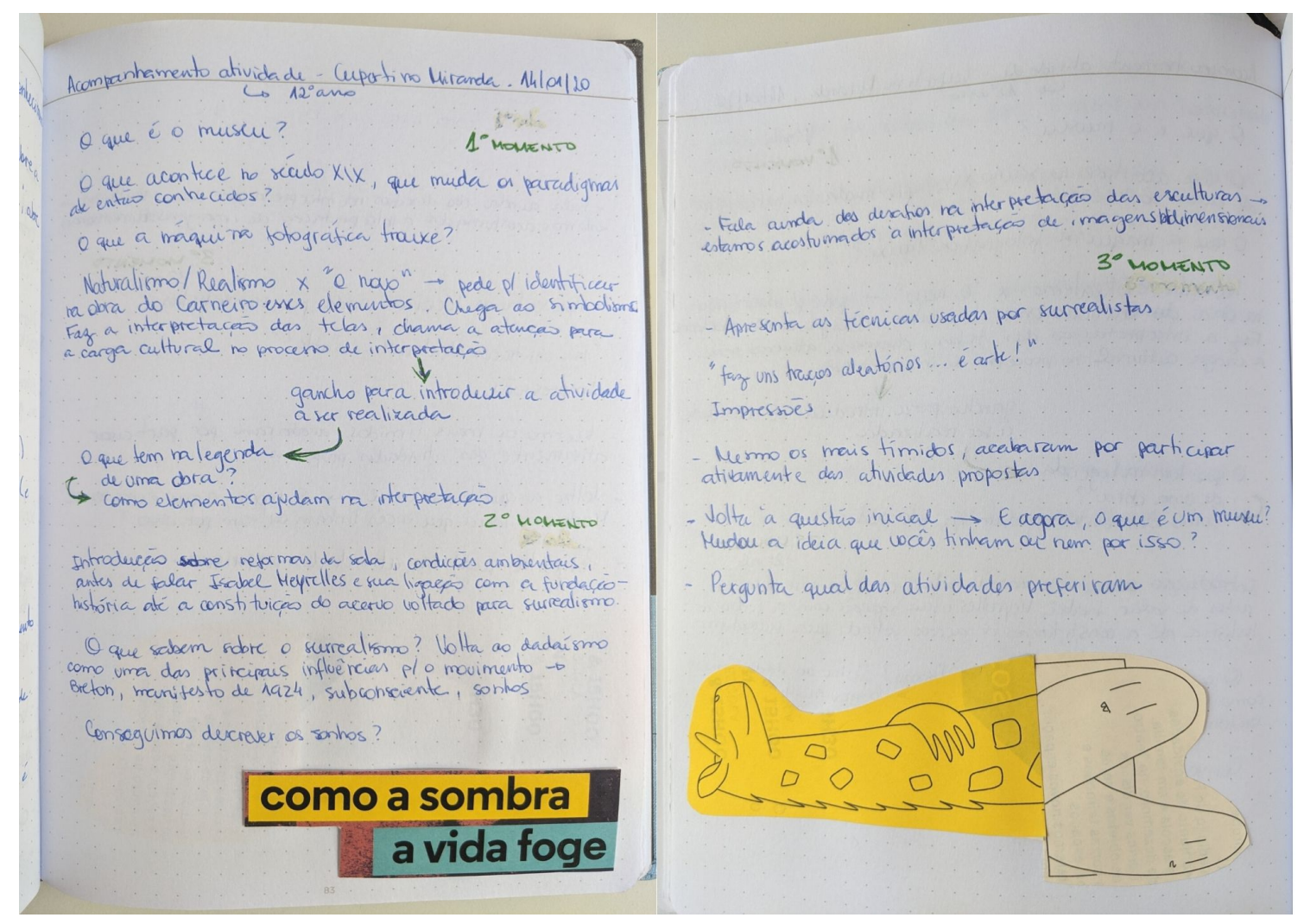

Fig. 1 - Exemplos dos apontamentos pessoais no diário. CLouise Palma, 2020. 
$\mathrm{Na}$ terceira fase, iniciou-se a recolha de dados, que estava dividida em duas etapas. Primeiro, as fichas de diagnóstico foram parcialmente preenchidas com informações recolhidas na revisão de documentos. Já a etapa seguinte aconteceria em contacto direto com os colaboradores, visando complementar o preenchimento das fichas de diagnóstico e recolher informações de caráter sociodemográfico. No entanto, a esta etapa foram impostas adaptações por conta da pandemia da COVID-19, que impactaram na dinâmica da recolha de dados, e, consequentemente, no cronograma previsto. Assim, a recolha de dados concentrou-se em apenas um profissional por unidade museológica, o contacto foi feito através de chamadas de vídeo e/ou áudio e a dinâmica estabelecida incluiu a revisão das fichas por parte dos colaboradores ${ }^{3}$. Na quarta fase, os dados foram sistematizados numa base de dados no Google Sheets. No caso dos dados oriundos das fichas de diagnóstico, foram criadas categorias gerais de análise, baseadas nas questões que orientaram a elaboração do instrumento: descrição da atividade, conceção e planeamento da atividade e realização da atividade. No entanto, foram encontradas lacunas nesse processo, que correspondem a perguntas que não foram respondidas por conta da inexistência de metodologias nas instituições relacionadas com a documentação, o registo e a análise das atividades realizadas. Elas foram, então, incluídas numa quarta categoria.

\section{Resultados e interpretação}

A interpretação dos dados baseou-se numa análise comparativa dos dados recolhidos com a bibliografia consultada, as conversas com os colaboradores durante a recolha dos dados e a vivência durante o período de estágio. E, para sintetizar os resultados e perceber, de uma maneira mais visual, as forças, fraquezas, oportunidades e ameaças identificadas nessa avaliação diagnóstica, foi utilizada a análise SWOT como ferramenta (Fig. 2).

3 Foram cumpridos todos os procedimentos éticos da investigação qualitativa e da comissão de ética da FLUP. 


\begin{tabular}{|c|c|c|c|}
\hline Strengths (Forças) & & & Weaknesses (Fraquezas) \\
\hline $\begin{array}{l}\text { - Forte atuação do serviço educativo } \\
\text { - Coleções diversificadas } \\
\text { - Ligação ao território e à comunidade } \\
\text { - Instituições museológicas consolidadas } \\
\text { - Público escolar cativo } \\
\text { - Equipas plurais, com experiências e formações } \\
\quad \text { diversas }\end{array}$ & & & \multirow{2}{*}{$\begin{array}{l}\text { - Equipas do serviço educativo reduzidas } \\
\text { - Falta de especialização dos colaboradores } \\
\text { - Sobrecarga de tarefas } \\
\text { - Divulgação das atividades } \\
\text { - Lacunas nas metodologias de registo, } \\
\text { documentação e análise das atividades } \\
\text { - Falta de autonomia no orçamento } \\
\text { - Trabalho com grupos minoritários } \\
\text { - Ausência de uma política de educação }\end{array}$} \\
\hline - Atividades oferecidas gratuitamente & s & W & \\
\hline Opportunities (Oportunidades) & 0 & $\mathbf{T}$ & Threats (Ameaças) \\
\hline $\begin{array}{l}\text { - Trabalho e programação em rede } \\
\text { - Ampliação de parcerias } \\
\text { - Temas transversais } \\
\text { - Formações internas } \\
\text { - Incentivo da Câmara Municipal de Vila Nova } \\
\text { de Famalicão } \\
\text { - Público sénior e famílias como potenciais }\end{array}$ & & & $\begin{array}{l}\text { - Cortes no orçamento da cultura } \\
\text { - Falta de transporte provido pela Câmara } \\
\text { - Municipal de Vila Nova de Famalicão } \\
\text { - Perda do registo histórico das atividades } \\
\text { - Perda do controlo justificar o trabalho realizado dados quantitativos } \\
\text { - Falta de inclusão }\end{array}$ \\
\hline
\end{tabular}

Fig. 2 - Análise SWOT dos resultados da avaliação diagnóstica à RMVNF. CLouise Palma, 2020.

Responderam ao inquérito 19 dos 30 colaboradores e foi possível constatar que as equipas são formadas, predominantemente, por profissionais do género feminino $(68,4 \%)$, de nacionalidade portuguesa, que residem nos distritos de Braga $(68,4 \%)$ e do Porto (21,1\%). É um grupo heterogéneo no que diz respeito à faixa etária, já que $84,2 \%$ têm idades entre os 31 e os 60 anos - dado que sugere experiência, estabilidade profissional e carreiras minimamente consolidadas. Apesar de 73,7\% dos funcionários terem cursado o ensino superior, apenas $15 \%$ apresentam formação relacionada com a Museologia e o Património.

Nas 10 unidades museológicas, predominam a tutela pública (60\%) e a gestão municipal (40\%) e isso se reflete, por exemplo, na predominância dos contratos por tempo indeterminado e nos cargos ocupados - que correspondem, na sua maioria (73,7\%), a carreiras gerais da função pública. No entanto, ao mesmo tempo que os dados indicam estabilidade, também indicam uma mobilidade interna reduzida.

Aferiu-se ainda que a maior parte das instituições tem equipas de serviço educativo formadas por um a quatro colaboradores (Fig. 3), que dividem o seu tempo com outras funções museológicas. Ou seja, falamos de equipas reduzidas e multifuncionais. 


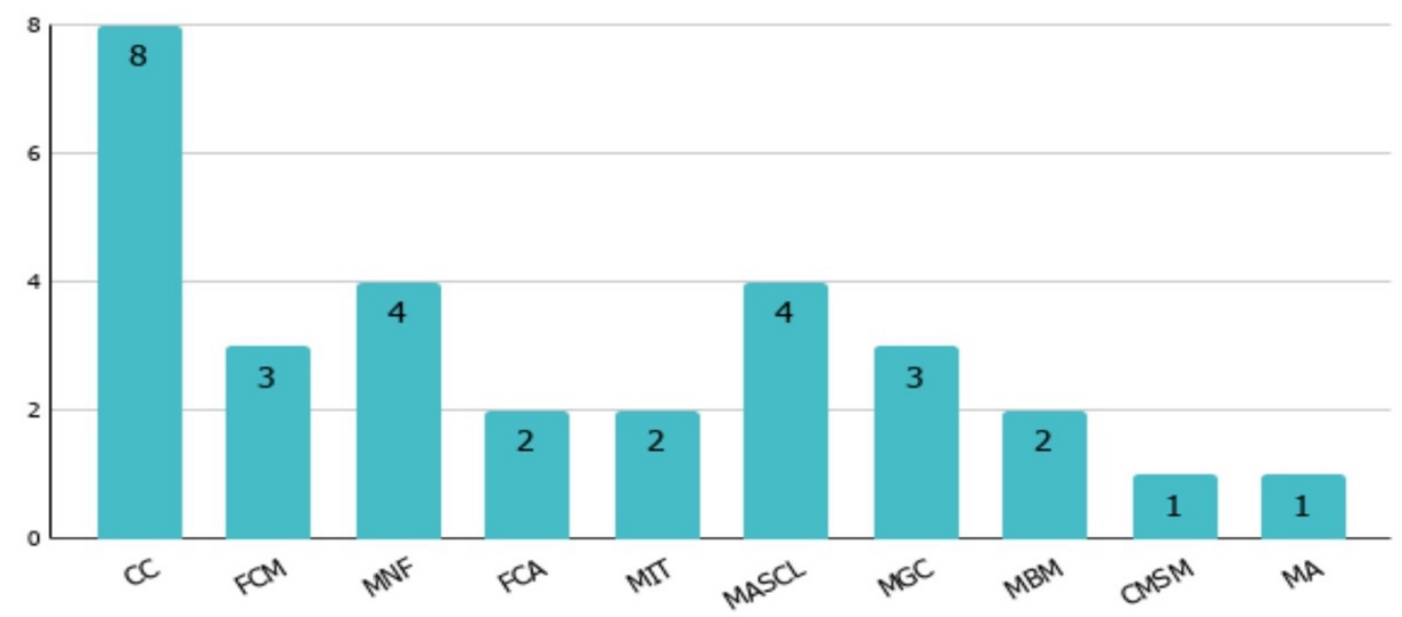

Fig. 3 - Número de colaboradores, por instituição, que atuou no serviço educativo dos museus da RMVNF, em 2019. CLouise Palma, 2020.

Através das fichas de diagnóstico, foram identificadas 94 atividades planeadas em 2019 (Fig. 4). É interessante notar que 65,9\% dessas atividades concentram-se em apenas três instituições, com relevância na atuação com a comunidade na área educativa. Isto reflete um serviço educativo com mais histórico e mais estruturado, tanto a nível de equipa, quanto de planeamento; em atividades mais diversas; e numa divulgação mais eficaz.

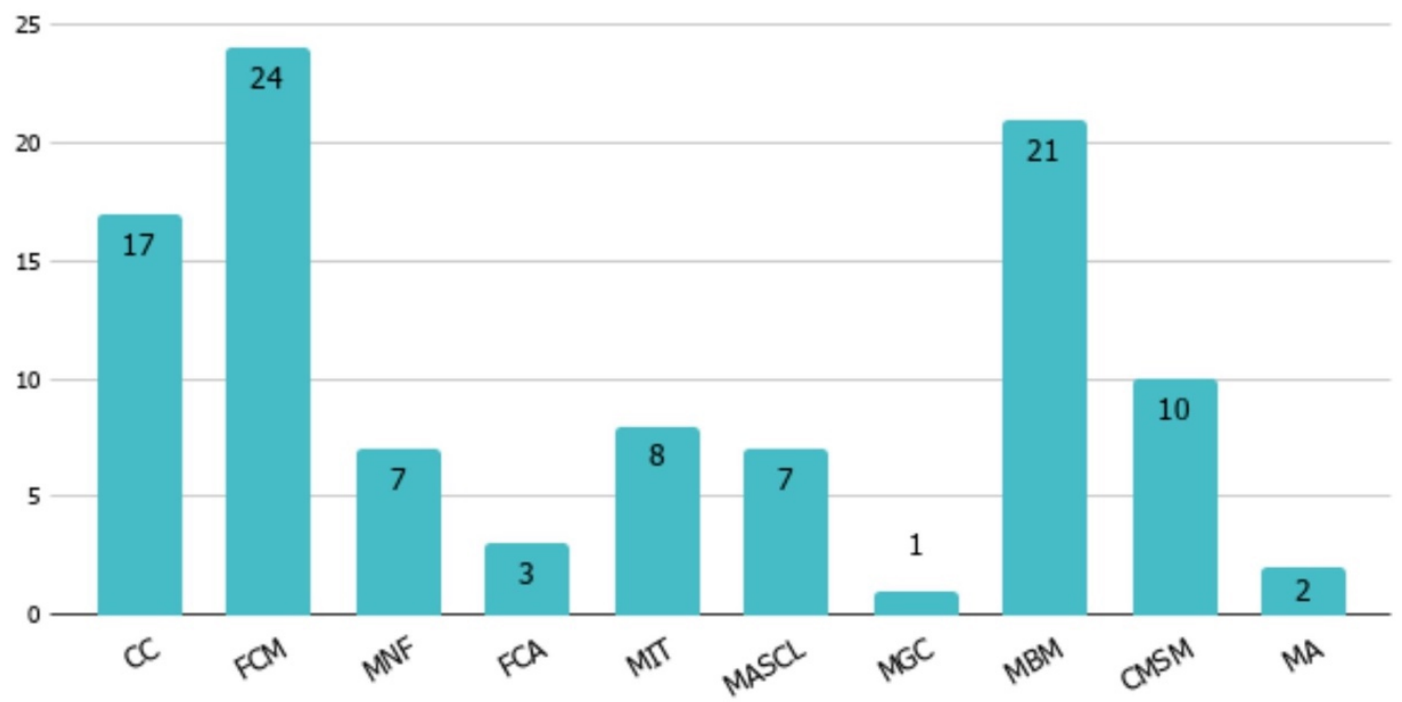

Fig. 4 - Número identificado de atividades no serviço educativo dos museus da RMVNF, por instituição. (CLouise Palma, 2020. 
Um ponto em comum é que nenhuma das 10 instituições possui uma política de educação, indo ao encontro dos dados fornecidos pelo "Panorama Museológico em Portugal". Segundo o relatório, a formalização do serviço educativo é pouco frequente nas instituições, tanto em documentos fundadores quanto nos documentos de gestão - "como a lei orgânica (para os serviços da Administração Central), regulamentos (obrigatórios) e estatutos (não obrigatórios)" (Neves, Santos \& Lima, 2013, p. 83).

Das 94 atividades planeadas, 15 não foram realizadas. Isso foi atribuído à falta de procura do público e, nesse ponto, é necessário refletir sobre a forma como elas foram comunicadas - seja pela sua apresentação, através do título e da sinopse, ou pelo meio de comunicação escolhido. Neste sentido, verificou-se uma relevância do sítio web das instituições na divulgação da sua programação do serviço educativo. No entanto, a falta de procura também foi atribuída a fatores externos, como a suspensão do transporte provido pela Câmara Municipal para levar grupos escolares aos museus. Por outro lado, nas 79 atividades realizadas foi possível identificar uma forte ligação com o público escolar. Isso fica muito claro na tipologia das atividades oferecidas, em que se destacam as visitas orientadas, e também na relação com o calendário escolar, que leva em conta o ano letivo e os períodos de férias. Essa presença do público escolar realça a consolidação das instituições da RMVNF como lugar de aprendizagem e como elo de ligação com a comunidade e com o território.

Ao olhar para os tipos de público contemplados pela programação, nota-se que é muito comum que as atividades sejam pensadas para serem adaptadas ou para servirem a "todos os públicos". Ainda assim, o ciclo básico ganha mais atenção na programação - ou seja, há um direcionamento para um público entre 6 e 14 anos, que visita o museu em contexto escolar.

Para além disso, destaca-se que o público com necessidades de apoio à aprendizagem aparece em apenas 10,6\% das atividades e em apenas das três instituições museológicas, as minorias sociais não são consideradas, e os visitantes com necessidades específicas são considerados em 39\% das atividades, apresentadas como 
"adaptáveis" por possibilitar que barreiras físicas, sociais e intelectuais impostas aos visitantes sejam contornadas.

No que se refere às lacunas relacionadas com a inexistência de metodologias nas instituições, destaca-se a falta na metodologia de documentação no âmbito do histórico das atividades do serviço educativo. Visto que nenhuma das instituições tinha isso organizado, o contributo da avaliação foi montar esse histórico com o material recolhido.

O lapso na metodologia de registo pode ser visto ao nível dos procedimentos, já que se notou que não foi uma prática recorrente registar como as atividades se desenvolviam. $E$, olhando para os resultados, identificou-se que o registo de visitantes e do número de sessões realizadas também apresentava falhas. No âmbito da metodologia de análise, destaca-se que a maior parte das atividades não foi avaliada, seja porque a avaliação ainda não é levada em conta como parte da elaboração das atividades, seja porque faltam competências neste domínio ou falta tempo entre os profissionais, sendo esta uma etapa pouco priorizada.

Outros pontos que merecem atenção são a carência no domínio acerca de algumas componentes teóricas do campo da museologia, atribuída à falta de uma formação especializada das equipas. No entanto, neste sentido, a RMVNF vem fazendo um trabalho a nível de instrução dos recursos humanos.

O orçamento destinado ao serviço educativo ainda é pouco representativo relativamente a outras áreas, e falta de autonomia dos profissionais em relação ao investimento feito. Isso exige da equipa muita flexibilidade - o que pode ser considerado um ponto positivo.

Por fim, nota-se um isolamento das atividades, já que elas não são articuladas em rede, não fazem parte de programas educativos nem de parcerias. Ou seja, apesar de estarem integrados numa organização reticular, os serviços educativos desses museus pouco se articulam. No entanto, é preciso ressaltar a oportunidade de pensar em rede. 


\section{Considerações finais}

O trabalho desenvolvido reforça a importância de integrar a avaliação como prática recorrente no âmbito dos museus, principalmente no que diz respeito à programação do serviço educativo. No contexto museológico, a avaliação diagnóstica mostra-se como um método vantajoso ao possibilitar que uma organização seja vista na totalidade, permitindo não só conhecer, mas reconhecer o que vem sendo feito no âmbito da educação.

Com relação à abordagem metodológica aplicada, destaca-se a possibilidade de adaptação da ficha de diagnóstico como base para outras avaliações diagnósticas. Essa mesma ficha pode ser ainda integrada como instrumento de conceção e registo das atividades do serviço educativo, permitindo que o processo de elaboração seja realizado a partir de uma visão sistémica (Semedo, 2019). A RMVNF vem trabalhando nesse processo, que pode tornar-se mais fluido, pois os colaboradores já estão mais familiarizados com o instrumento.

Ao inspirar-se no paradigma transformador, esta avaliação tem em vista um impacto concreto na realidade. Olhando para a RMVNF, espera-se que esse estudo sirva de ponto de partida para a mudança de pensamento e de atitude no que diz respeito à perceção sobre a relevância da avaliação e da sua utilização como forma de fundamentar procedimentos e promover melhorias no serviço educativo. Entende-se que esta é uma forma de dar continuidade ao trabalho aqui iniciado.

Outra continuidade possível é considerar a avaliação diagnóstica realizada como um primeiro passo na elaboração de uma política de educação. Pretende-se que o contributo se estenda à reafirmação da função educativa da organização, apoiando a elaboração de um programa educativo em rede.

Por fim e de maneira mais ampla, espera-se que este estudo possa contribuir para a reflexão sobre a necessidade de desenvolver modelos de avaliação voltados para a utilização em contextos museológicos. 


\section{Agradecimentos}

À orientação de Alice Semedo e coorientação de Liliana Aguiar, e à Rede de Museus de Vila Nova de Famalicão e todos os seus colaboradores, envolvidos direta ou indiretamente no estudo desenvolvido.

\section{Referências}

- Creswell, J. W. (2014). Research Design: Qualitative, Quantitative, and Mixed Methods Approaches ( $4^{\text {th }}$ ed.). Los Angeles: Sage Publications.

- Denzin, N. K., \& Lincoln, Y. S. (Eds.) (2005). Handbook of Qualitative Research ( $3^{\text {rd }}$ ed.). Thousand Oaks: Sage Publications.

- Guba, E. G. (1990). The alternative paradigm dialog. In E. G. Guba (Ed.), The Paradigm Dialog (pp. 17-27). S. Francisco: Sage Publications.

- Korn, R. (1989). Introduction to evaluation: theory and methodology. In: N. Berry \& S. M. Mayer (Eds.), Museum Education: History, Theory, and Practice (pp. 219-238). Reston: National Art Education Association.

- Mertens, D. M. (2009). Transformative Research and Evaluation. New York: The Guilford Press.

- Mertens, D. M., \& Wilson, A. T. (2018). Program Evaluation Theory and Practice. New York: Guilford Publications.

- Neves, J. S., Santos, J. A., \& Lima, M. J. (2013). O Panorama Museológico em Portugal: Os Museus e a Rede Portuguesa de Museus na Primeira Década do Século XXI. Direção-Geral do Património Cultural. http://www.patrimoniocultural.gov.pt/static/data/publicacoes/opanoramamus eologicoemportugal_bq.pdf

- Ornellas, G., Palma, L., \& Sbragio, T. (2018). Relatório da Visita Orientada. Aurélia de Sousa, o Autorretrato e a Construção da Identidade. Documento não publicado. Porto: FLUP. 
- Pérez Santos, E. (2000). Estudio de Visitantes en Museos: Metodologia y Aplicaciones. Gijón: Trea.

- Rede de Museus de Vila Nova de Famalicão (Ed.) (2019). Definir a Missão... da Necessidade ao Desafio. Vila Nova de Famalicão: Câmara Municipal de Vila Nova de Famalicão.

- Rede de Museus de Vila Nova de Famalicão. (2019b, 16 de maio). Museu é um lugar de... [vídeo anexado] [atualização de status]. Facebook. Retirado de

- https://www.facebook.com/watch/?v=712249502523715\&extid=QTCx619YJ4o KVRAO.

- Semedo, A. (2019). Toolbox: Museus. Património. Educação. (Documento não publicado). Porto: Faculdade de Letras da Universidade do Porto.

- Stufflebeam, D. L., \& Coryn, C. L. (2014). Evaluation Theory, Models, and Applications ( $2^{\text {nd }}$ ed.). S. Francisco: Jossy-Bass.

- Vilela, L. P. (2020). Avaliação Diagnóstica de Serviços Educativos: O caso da Rede de Museus de Vila Nova de Famalicão (Dissertação de Mestrado, Universidade do Porto, Porto, Portugal). Disponível em https://repositorioaberto.up.pt/handle/10216/130660 


\section{Sofia Navalho}

sofianavalho28@gmail.com

Casa-Museu Soledade Malvar: edifício, coleção e inventário. 
Resumo

Este texto tem como objetivo descrever o processo de desenvolvimento do Relatório de Estágio intitulado "Casa-Museu Soledade Malvar - Edifício, Coleção e Inventário", elaborado no âmbito do Mestrado de Museologia da FLUP. O Relatório centra-se no estudo da história da Casa-Museu Soledade Malvar e de uma pintura pertencente ao seu acervo. Este foca-se, igualmente, no processo de leitura, análise e revisão das mais recentes fichas de inventário da casa-museu.

O contributo inicia-se com uma descrição do tema da investigação e com uma apresentação da casamuseu e da história da sua criação. Segue-se a descrição pormenorizada do processo de desenvolvimento do Relatório, mencionando todas as etapas que levaram ao resultado final. Por fim, são apresentadas as considerações finais, refletindo sobre as dificuldades que surgiram e sobre os contributos que resultaram da investigação desenvolvida.

Palavras-chave: Estudo de coleção; Inventário; CasaMuseu; Museologia

\section{Nota biográfica}

Sofia Navalho é Licenciada em História da Arte e Mestre em Museologia, pela Faculdade de Letras da Universidade do Porto. Durante o seu 2.ㅇ ciclo de estudos, no Mestrado em Museologia, realizou um Estágio na Casa-Museu Soledade Malvar, instituição museológica pertencente à Rede de Museus de Vila Nova de Famalicão. Desenvolveu ainda algumas atividades com esta mesma rede de museus, tais como a criação e gravação de uma visita guiada intitulada "Um riacho - O naturalismo de Júlio Ramos" e a publicação de um artigo, que integrará o Boletim Cultural de Vila Nova de Famalicão, de 2021.

\section{Abstract}

This text has the purpose of demonstrating the process of the development of the Internship Report intitled "Casa-Museu Soledade Malvar - Edifício, Coleção e Inventário", created within the scope of the master's degree in Museology at FLUP. This Report focuses on the study of the history of the Casa-Museu Soledade Malvar and a painting that belongs to its collection. It focuses, as well, on the process of reading, analysing and reviewing the most recent inventory sheets from this house museum. The contribute starts with a description of the research's theme and a presentation of the CasaMuseu Soledade Malvar and the history of its creation. After that, there is a description of the report's development process, mentioning all the steps that led to its results. Lastly, final considerations are presented, reflecting on the difficulties and on the contributions that resulted from the developed research.

Keywords: Collection studies; Inventory; House Museum; Museology

\section{Biographical note}

Sofia Navalho has a degree in Art History and a master's degree in Museology, from the Faculty of Arts and Humanities of the University of Porto. During her $2^{\text {nd }}$ cycle of studies, the Masters in Museology, she held an internship in Casa-Museu Soledade Malvar, a museological institution belonging to the Vila Nova de Famalicão Museum Network.

She also developed some activities with the same museum network, such as the creation and recording of a guided tour entitled "A stream - The naturalism of Júlio Ramos" and the publication of an article, which will be included in the Cultural Bulletin of Vila Nova de Famalicão, of 2021. 


\section{Introdução}

Este contributo tem como propósito partilhar o essencial do processo que levou à elaboração do Relatório de Estágio, desenvolvido no âmbito da conclusão do Mestrado em Museologia (MMUS) da Faculdade de Letras da Universidade do Porto (FLUP), sob a orientação de Alice Semedo e Mariana Jacob (Navalho, 2020). O Relatório, apresentado em finais de 2020, resulta de um estágio curricular, de 400 horas de duração, realizado na Casa-Museu Soledade Malvar. Os temas abordados nesse documento focam-se no estudo da história da casa-museu e das suas transformações, assim como no de uma pintura pertencente ao seu acervo, da autoria do pintor naturalista Júlio Ramos, centrando-se, igualmente, na leitura e revisão crítica das mais recentes fichas de inventário de pintura da instituição museológica.

Este texto inicia-se com uma breve apresentação da Casa-Museu Soledade Malvar e da história da sua criação, com o objetivo de a dar a conhecer aos leitores. Nela, inclui-se também uma pequena biografia da antiquária e colecionadora, que dá nome à instituição e que é a responsável pela sua existência. De seguida, são indicados os motivos que levaram à seleção da instituição como local de estágio, os objetivos de trabalho e a descrição das várias fases de desenvolvimento, apresentando os vários conceitos analisados e o processo de seleção do modelo de estudo de coleções que serviu de base ao estudo da pintura "Um riacho" (Milheiroz). Posteriormente, são descritas as quatro fases de investigação sobre a pintura mencionada, referindo as informações recolhidas em cada uma e as dificuldades que foram surgindo ao longo desse processo, refletindo sobre as alternativas adotadas para as ultrapassar.

\section{A Casa-Museu Soledade Malvar}

A Casa-Museu Soledade Malvar (CMSM) surge de um interesse, por parte da antiquária e colecionadora, Maria da Soledade Ramos Malvar Osório, de criar um 
museu, com o intuito de doar à comunidade famalicense a sua coleção (Rede de Museus de Vila Nova de Famalicão, 2018).

Figura conhecida em Vila Nova de Famalicão, de onde é natural, Maria da Soledade desenvolveu um particular interesse pela arte, desde a sua infância. O gosto pelas antiguidades, que foi desenvolvendo ao longo da vida, culmina na abertura de um Bricà-Brac, frequentado por importantes figuras nacionais (Rede de Museus de Vila Nova de Famalicão, 2002). Esta vontade de criar uma instituição museológica é concretizada em 1998, a partir da elaboração de uma escritura, onde foi acordada a doação, ao Município de Vila Nova de Famalicão, do prédio urbano pertencente a Maria da Soledade e dos 414 objetos pertencentes à sua coleção. Estes foram seccionados em 3 categorias, designadas por “Mobiliário, Porcelanas e Esculturas”, "Ourivesaria” e “Pintura” (Câmara Municipal de Vila Nova de Famalicão, 1998).

A 29 de setembro de 2002, a casa-museu é inaugurada, após um período de obras de adaptação do edifício à função museológica, realizado com o propósito de respeitar o traçado original do edifício, de forma que o ambiente doméstico vivenciado pela colecionadora se mantivesse (Rede de Museus de Vila Nova de Famalicão, 2018). As obras tiveram uma duração de cerca de dois anos, tendo sido executadas pela Firma Andrade \& Almeida - Construções Lda. (Câmara Municipal de Vila Nova de Famalicão, 2000), cujo projeto foi selecionado a partir da abertura de um concurso público. Durante esta fase de construção e remodelação, os objetos doados por Maria da Soledade foram transferidos para um apartamento seu, à exceção das peças de joalharia (Câmara Municipal de Vila Nova de Famalicão, s.d.). Algumas das alterações executadas respeitam a transformação do anterior Bric-à-Brac numa sala de exposições temporárias, ou a demolição do quarto de vestir. Ainda durante este período, o anterior quarto de hóspedes foi convertido na sala onde atualmente são expostos os objetos de joalharia (Câmara Municipal de Vila Nova de Famalicão, 2000).

A CMSM pertence à Rede de Museus de Vila Nova de Famalicão (RMVNF), criada em novembro de 2012, na procura de tornar o património cultural famalicense um 
potenciador de visitação turística (Câmara Municipal de Vila Nova de Famalicão, 2012). A RMVNF demonstra uma preocupação com a proteção da herança patrimonial de Vila Nova de Famalicão, com a comunidade e o com desenvolvimento da mesma, a partir da utilização de um sistema pedagógico e educativo. Acresce a estas preocupações a vontade de promover a identidade do concelho e da sua comunidade (Câmara Municipal de Vila Nova de Famalicão, 2012). É composta por 12 unidades museológicas, com caráter de coleção visitável, ou de museu.

A CMSM localiza-se no número 104 da Avenida 25 de abril (Fig. 1) e é composta por uma grande variedade de objetos, anteriormente pertencentes à colecionadora e antiquária Maria da Soledade Malvar (Rede de Museus de Vila Nova de Famalicão, 2018).

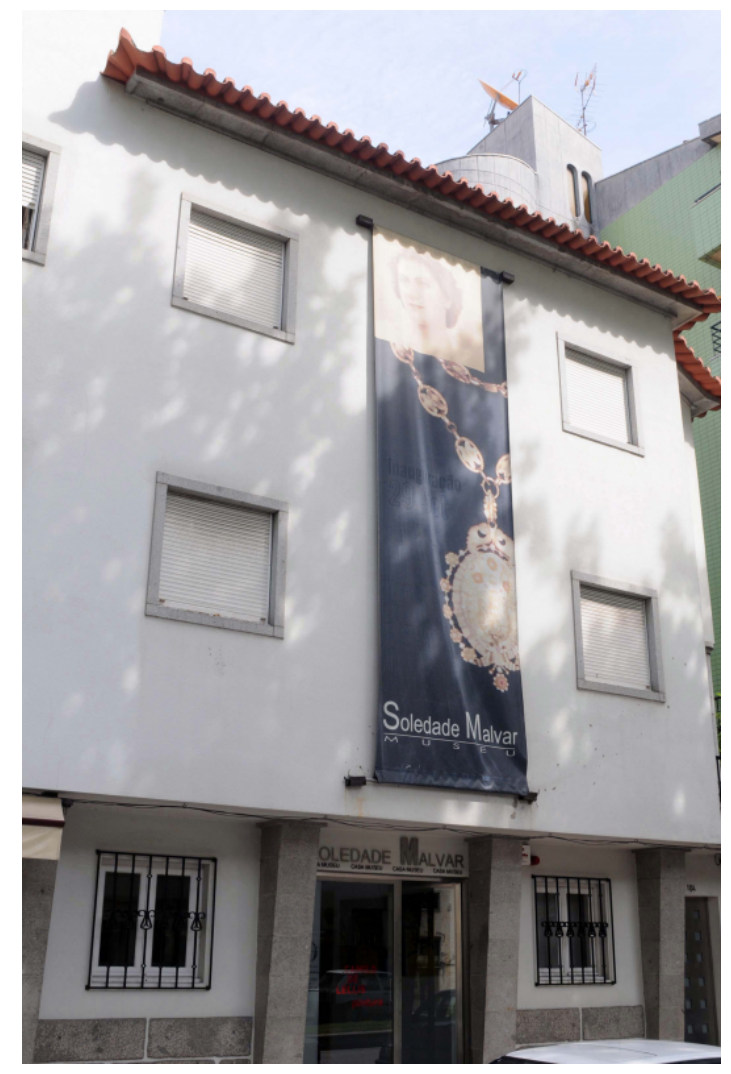

Fig. 1 - Fachada da Casa-Museu Soledade Malvar (Câmara Municipal de Vila Nova de Famalicão, s.d.). 
Entre os 553 objetos em causa, encontram-se algumas esculturas, das quais se destaca a imagem de Santo António, exposta em local de destaque, no piso térreo do edifício. A coleção é também composta por objetos das categorias Numismática e Têxteis (incluindo vestuário de criança e tapeçarias). O mobiliário apresenta-se em grande número e abrange uma diversidade de objetos, como cadeiras e diferentes tipos de cómodas e mesas, de maior ou menor dimensão. Os objetos de cerâmica estão expostos um pouco por todo o edifício, mas concentram-se, sobretudo, num armário de grandes dimensões, situado no $1 \cong$ piso do museu. As peças de ourivesaria localizam-se no $2 \cong$ piso, numa sala própria, que apresenta condições de segurança específicas, devido à natureza deste tipo de objetos. A restante coleção inclui algumas fotografias (que retratam membros da família de Maria da Soledade, ou a própria colecionadora), gravuras e algumas peças que se inserem nas categorias de Metais e de Vidros.

Todos estes objetos se encontram inventariados - tendo em conta as normas de preenchimento de dados incluídas no programa In Patrimonium.Net - e foram adquiridos em diversos antiquários (Câmara Municipal de Vila Nova de Famalicão, 2002) ou em leilões. A grande maioria encontra-se em exposição permanente, estando disposta pelo rés-do-chão e, sobretudo, pelos 10 e 20 pisos do edifício. À exceção da coleção de ourivesaria, todos os objetos, das mais variadas categorias, convivem nas mesmas salas de exposição desta casa-museu.

A coleção de pintura é composta por 21 objetos, de diferentes formatos e dimensões, cuja maioria data do século XIX e XX. Muitas destas peças integram o acervo da casamuseu desde 1997, embora a maior parte tenha sido doada apenas em 2003. À exceção de uma pintura a aguarela sobre papel, todas as restantes foram executadas a óleo, sendo, sobretudo, a óleo sobre tela (14, no total). As restantes são a óleo sobre pergaminho, cobre ou madeira. As temáticas abordadas são a religiosa, que se apresenta em maior número, seguida da natureza-morta, da paisagem e do retrato. A maioria encontra-se em exposição permanente e distribui-se por toda a casa-museu, embora se concentre, maioritariamente, na sala de jantar, localizada no 10 piso do 
edifício. Em reserva, encontram-se apenas 6 pinturas, envoltas em espuma de polietileno. Algumas estão colocadas numa estante de metal e as restantes estão encostadas a uma parede e pousadas sobre placas de cartão, posicionadas no chão.

A CMSM pretende transmitir aos visitantes os conhecimentos sobre Maria da Soledade Malvar e divulgar o seu legado (Rede de Museus de Vila Nova de Famalicão, 2019). Do mesmo modo, a casa-museu procura ser um "lugar de encontro entre gerações", onde se tenciona alcançar o "desenvolvimento pleno de cada pessoa na sua relação com a comunidade local” (Rede de Museus de Vila Nova de Famalicão, 2019, p. 49).

\section{Metodologia}

O processo de desenvolvimento do Relatório de Estágio teve início no momento em que foi selecionado o local de Estágio e em que foram ponderados os temas a abordar. A escolha da Casa-Museu Soledade Malvar derivou de uma visita ao local e de uma conversa com uma das responsáveis pela coordenação da RMVNF. Durante o primeiro contacto com os objetos da coleção do museu, aqueles que despertaram maior interesse foram as pinturas, que não se encontravam estudadas. Deste modo, optouse por realizar um estudo sobre as mesmas e, ainda, uma investigação relativa à história do edifício.

Uma das fases iniciais desta investigação prendeu-se com o delinear dos objetivos. Estes basearam-se na tentativa de contribuir para a recolha de informações sobre a pintura estudada e sobre a história da Casa-Museu Soledade Malvar, procurando desenvolver uma investigação que resultasse na introdução de novos dados nas fichas de inventário do museu.

De forma a organizar as várias tarefas de investigação, desenvolveu-se um cronograma, que acabou por não ser cumprido da forma prevista. Registaram-se alguns atrasos, devido a obstáculos decorrentes da pandemia de COVID-19. 
A fase que se seguiu focou-se na elaboração de uma reflexão teórica relativa ao conceito de coleção e a várias questões relacionadas com o tema. A leitura e interpretação de vários textos, especialmente de Pearce (2003a; 2003b; 2003c) e Belk (2003), permitiu produzir uma reflexão sobre os vários modos de colecionar, as motivações subjacentes à prática de colecionar e o significado e importância que os objetos possuem.

De seguida, foram estudados textos que apresentam diferentes abordagens ao tema da cultura material. O objetivo foi demonstrar a forma como, dentro do mesmo tema, se podem registar perspetivas muito distintas. Pela sua relevância, destacam-se os de Appadurai (1986) e de Kopytoff (1986).

Posteriormente e tendo em consideração que uma parte significativa da investigação se centrava na história da Casa-Museu Soledade Malvar, tornou-se fundamental efetuar uma reflexão sobre o conceito de casa-museu e explicar por que razão é que esta instituição museológica se enquadra nesse contexto. Para tal, revestiram-se de grande importância as publicações de Ponte (2007; 2019) e de Günhan (2011).

Foram também considerados alguns modelos de estudo de coleções, como os de Batchelor (2003), Elliot (2003), Pearce (2003) e Prown (2003). O modelo de Pearce foi o adotado para a realização do estudo de uma pintura, por se considerar ser o que melhor se adequava ao tipo de objeto selecionado e que oferecia uma análise mais completa do mesmo.

O processo de seleção de uma das pinturas não estudadas resultou da consulta das informações existentes nas mais recentes fichas de inventário da CMSM. Após observar a escassez de dados referentes à grande maioria dos objetos, optou-se por efetuar um estudo sobre a obra "Um riacho" (Milheiroz), de Júlio Ramos (Fig. 2). 


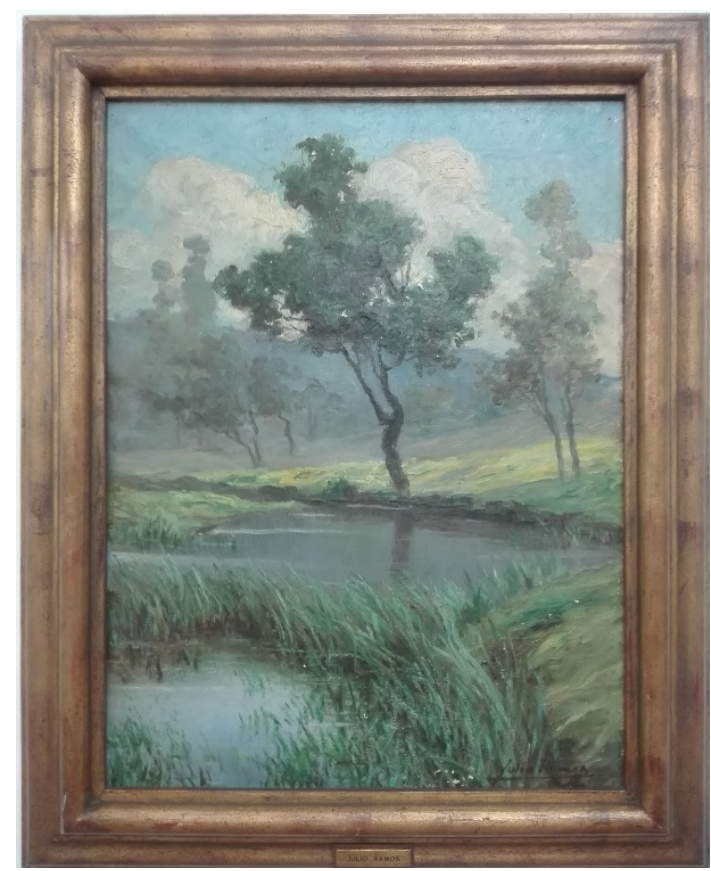

Fig. 2 - Pintura "Um riacho" (Milheiroz), de Júlio Ramos. (C Sofia Navalho, 2019.

Tratando-se de uma pintura assinada de um autor reconhecido, depreendeu-se que existiriam informações suficientes para se proceder ao seu estudo. O modelo de Pearce foi adaptado às características do objeto e às informações que foram sendo recolhidas, mantendo-se a sua organização em 4 fases distintas: o "material", a "história" - seccionada em dois momentos -, o "contexto" e o "significado". A primeira fase focou-se na observação atenta e na descrição detalhada do objeto, a partir do seu exame. De seguida, foram consultadas algumas obras de artistas naturalistas, como Jean-Baptiste Corot e Charles-François Daubigny, de modo a estabelecer uma comparação entre a pintura em estudo e outras que se inserem no mesmo movimento artístico. De seguida, procurou-se consultar a obra artística de Júlio Ramos, com o objetivo de compreender as suas principais características e de estabelecer uma comparação entre as várias obras e a pintura "Um riacho" (Milheiroz). Devido à 
situação pandémica e ao encerramento de instituições museológicas, as pinturas existentes nos acervos dos museus não puderam ser consultadas presencialmente ${ }^{1}$.

Para esta comparação, utilizaram-se as pinturas retratadas no catálogo da exposição de homenagem a Júlio Ramos (Salão Silva Porto, 1943) e algumas apresentadas no site da Leiloeira S. Domingos (s.d.).

A fase que se refere à "história" foi seccionada em dois momentos distintos. $\mathrm{O}$ primeiro abordou a história geral do objeto, procurando aprofundar os conhecimentos sobre o seu autor e recolher informações sobre os proprietários anteriores. Para este fim, foram contactados o Ateneu Comercial do Porto e alguns antiquários e leilões das regiões de Vila Nova de Famalicão, Braga e Porto. Porém, as respostas foram escassas e nenhuma informação pôde ser recolhida a partir deste método. Recolheu-se, também, informação sobre a biografia de Júlio Ramos, referente ao seu percurso académico (Universidade Digital/Gestão de Informação, 2009) e à sua carreira artística (Pamplona, 1991).

O segundo momento focou-se na história da pintura, desde o momento em que passou a fazer parte do acervo da CMSM. A partir de testemunhos orais e escritos de antigos funcionários da instituição, procurou saber-se o histórico das movimentações e transformações que o objeto foi tendo, questionando os intervenientes sobre os locais onde a pintura foi exposta ou sobre a possibilidade de ter sofrido algum restauro.

A fase do "contexto" foi marcada pelo estudo do contexto histórico e cultural da corrente artística em que se enquadra a pintura. A partir da leitura de bibliografia sobre o Naturalismo (Guinsburg \& Faria, 2017) e a história do Naturalismo em Portugal (França, 2002), foi possível compreender a forma como esta corrente artística surgiu e influenciou os artistas portugueses

\footnotetext{
${ }^{1}$ No acervo do Museu Nacional Grão Vasco existe uma pintura de Júlio Ramos, denominada Paisagem, e no Museu Nacional de Arte Antiga, estão quatro exemplares, denominados Tempestade próxima, Manhã, Azenha do Bicho, no Ave e Sinfonia de cor. O Museu Nacional de Soares dos Reis possui igualmente obras deste autor, embora não tenha sido conseguida a informação sobre quais as existentes
} 
A última fase deste estudo procurou compreender as motivações que levaram Maria da Soledade Malvar a adquirir a obra "Um riacho" (Milheiroz). Para responder a esta questão, tornou-se importante aprofundar os conhecimentos sobre Soledade Malvar e os seus hábitos de colecionar. Para este fim, foram consultados vários documentos existentes no acervo documental da Casa-Museu, tendo sido utilizada, sobretudo, a brochura intitulada Casa-Museu Soledade Malvar/Roteiro (Rede de Museus de Vila Nova de Famalicão, 2002), visto que este documento menciona a grande parte da informação referida nos restantes. A informação recolhida mostrou-se um pouco escassa, o que implicou a necessidade de utilizar outros métodos. É neste sentido que surge a visita à Quinta dos Cónegos, no concelho da Maia, local onde a colecionadora anteriormente residiu, e que permitiu recolher pequenos dados sobre esta fase da vida de Soledade Malvar.

Finalmente, de forma a complementar os dados biográficos sobre Maria da Soledade, realizaram-se duas entrevistas. O objetivo inicial era entrevistar um número maior de pessoas que tivessem criado diferentes tipos de relacionamento com a colecionadora. Apesar destes intentos, a propagação do coronavírus SARS-CoV-2 impossibilitou a concretização de um vasto número de entrevistas, em tempo útil.

\section{Resultados e discussão}

De um modo geral, os dados recolhidos permitiram desenvolver as referidas quatro fases de estudo da pintura. Porém, algumas questões relacionadas com a história deste objeto não puderam ser respondidas. Os esforços direcionados para a procura dos locais onde Soledade Malvar adquiria as suas pinturas não resultaram em quaisquer informações. Isto deve-se à falta de resposta, por parte dos antiquários e leilões contactados e à inexistência de qualquer documentação que pudesse comprovar a compra dos objetos. 
No que diz respeito à história da CMSM e das suas transformações, sobretudo aquelas executadas durante o período de obras entre 2000 e 2002, a recolha de referências foi pouco determinante para a investigação, visto que as únicas dissertações que a referem (Moreira, 2006; Ponte, 2007) descrevem-na apenas de forma breve. Pelo contrário, a consulta do acervo documental da CMSM revelou-se fundamental. Inclui vários documentos que referem as alterações realizadas durante as obras de $2000 \mathrm{e}$ 2002 e o processo do armazenamento e transporte dos objetos durante esta fase. Os dois conjuntos consultados de fotografias antigas, de datações distintas, que retratam a CMSM numa fase anterior às obras referidas, revelaram-se importantes para o estudo do edifício, permitindo conhecer o aspeto anterior do edifício e estabelecer uma comparação com o atual. Ao contrário do que se esperava, este processo de comparação tornou-se difícil, uma vez que, para além da disposição dos objetos ter sido alterada significativamente, muitas das fotografias demonstram apenas uma pequena parte de cada divisão do edifício. Ora, esta situação resultou na dificuldade em identificar as divisões da casa e obrigou, em último recurso, a comparar apenas os espaços que foram reconhecidos, que correspondem aos atuais espaços expositivos da CMSM. Em contexto das entrevistas, foi possível compreender as motivações que levaram à alteração significativa da organização e disposição das divisões do edifício. Conclui-se que esta alteração foi efetuada num momento em que várias peças, anteriormente doadas, se encontravam na posse de Maria da Soledade e por sua vontade. As modificações devem-se, igualmente, ao facto desta disposição dos objetos ter sido realizada de uma forma intuitiva, não seguindo, concretamente, a apresentação que o edifício anteriormente mostrava.

Parte do Relatório de Estágio desenvolvido focou-se, também, na descrição e reflexão crítica sobre as atividades complementares de estágio, realizadas, maioritariamente, na CMSM. Estas foram seccionadas em 4 tipologias distintas, denominadas "encontros científicos", "estudo de coleções", "serviços educativos" e "tratamento arquivístico". Entre estas, incluem-se as atividades da RMVNF, que permitiram conhecer a dinâmica entre os museus que a integram. Aliada a esta atividade, também a visita aos vários 
museus pertencentes a esta Rede, trouxe a oportunidade de conhecer o património famalicense e a forma como estes se envolvem com a comunidade de Vila Nova de Famalicão. Uma grande parte das atividades desenvolvidas foi executada com o intuito de recolher informação útil para a investigação.

A última fase de investigação foi desenvolvida juntamente com a colega de estágio, Thalita Sbragio, e diz respeito à leitura e revisão das fichas de inventário da CMSM, o que permitiu conhecer o tipo de material de suporte que os objetos de pintura apresentam a sua localização dentro do museu. A tarefa permitiu, ainda, identificar lacunas e surgiu a necessidade de inserir informação. Para este exercício foram consultadas as normas de gestão e inventariação de coleções SPECTRUM (Collections Trust, 2014) e do IPM - Instituto Português dos Museus (Instituto Português dos Museus, 2000-2010), para além do manual de apoio ao preenchimento de dados do sistema In Patrimonium. Net. Foram adotadas as normas estabelecidas por este sistema, já utilizadas pela RMVNF nas suas instituições museológicas. Desta atividade resultou um conjunto de novas fichas e um manual de auxílio ao preenchimento deste tipo de documentos. A este manual foi acrescentado um glossário, com a definição de alguns termos relacionados com as técnicas de pintura.

\section{Considerações finais}

Apesar da existência de uma quantidade significativa de instituições museológicas em Portugal, grande parte das mesmas não possui capacidades económicas para apostar no estudo dos objetos que possuem. Este é o caso da CMSM que, até então, não tinha desenvolvida nenhuma investigação aprofundada sobre os objetos da sua coleção. Tal situação reflete-se ao nível da documentação sobre as coleções. Tendo em conta este contexto, a realização do estágio referido e a redação do respetivo relatório permitiram colmatar algumas destas lacunas. Assim, a investigação desenvolvida torna-se um válido contributo para a instituição, globalmente. 


\section{Agradecimentos}

A autora expressa os seus agradecimentos às suas orientadoras e aos vários membros da Rede de Museus de Vila Nova de Famalicão, pelo acolhimento e pelo apoio na elaboração do estágio. Um especial agradecimento à colega Thalita Sbragio, pelo trabalho de parceria na execução das atividades e na realização do processo de leitura e revisão das fichas de inventário da CMSM

\section{Referências}

- Appadurai, A. (1986). Introduction: commodities and the politics of value. In A. Appadurai (Ed.), The Social Life of Things (pp. 3-60). Cambridge: Cambridge University Press.

- Batchelor, R. (2003). Not looking at kettles. In S. Pearce (Ed.), Interpreting Objects and Collections (pp. 139-143). London and New York: Routledge.

- Câmara Municipal de Vila Nova de Famalicão (s.d.). Acta. Câmara Municipal. V. N. Famalicão.

- Câmara Municipal de Vila Nova de Famalicão (1998). Escritura de Doação. Câmara Municipal. V. N. Famalicão.

- Câmara Municipal de Vila Nova de Famalicão (2000). Concurso Público "Remodelação de Edifício a Casa-Museu Soledade Malvar". Câmara Municipal. V. N. Famalicão.

- Câmara Municipal de Vila Nova de Famalicão (2002). Cultura e Turismo: O Perfil de Maria da Soledade Malvar [Press release]. Disponível em: https://www.cmvnfamalicao.pt/_o_perfil_de_maria_da_soledade_malvar 
- Câmara Municipal de Vila Nova de Famalicão (2012). Cultura e Turismo: Museus de Famalicão Unem-se em Rede e Apostam no Turismo. [Press release]. Disponível em: https://www.cmvnfamalicao.pt/_museus_de_famalicao_unemse_em_rede_e_apostam_no_tur ismo

- Collections Trust (2014). Spectrum 4.0 - Padrão para Gestão de Coleções de Museus do Reino Unido (Collections Trust). São Paulo: Secretaria de Estado da Cultura; Associação de Amigos do Museu do Café; Pinacoteca do Estado de São Paulo.

- Elliot, R. (2003). Towards a material history methodology. In S. Pearce (Ed.), Interpreting Objects and Collections (pp. 109-124). London and New York: Routledge.

- França, J. (2002). A Arte Portuguesa de Oitocentos. Lisboa: Instituto de Cultura e Língua Portuguesa.

- Guinsburg, J., \& Faria, J. (2017). O Naturalismo. S. Paulo, Brasil: Editora Perspectiva S.A.

- Günhan, A. (2011). From Houses to House Museums: Architectural Representation of Different Narrations. (Dissertação de Mestrado. The Graduate School of Natural and Applied Sciences of Middle East Technical University, Turkey). Disponível em: https://open.metu.edu.tr/handle/11511/20883

- Instituto Português dos Museus (2000-2010). Normas de Inventário. Disponível em: http://www.matriznet.dgpc.pt/matriznet/Normas/nventario.aspx.

- Kopytoff, I. (1986). The cultural biography of things: commoditization as process. In A. Appadurai (Ed.), The Social Life of Things (pp. 64-91). Cambridge: Cambridge University Press. 
- Leiloeira S. Domingos (s.d.). LEILÕES / Leilão 2019 - 93: Júlio Ramos. Disponível em:

https://www.leiloeirasaodomingos.pt/leilao/2019.93/0/1/2/05/J\%C3\%BAlio\%2 ORamos $/ 0 / 0$

- Moreira, M. R. (2006). Da Casa ao Museu: Adaptações Arquitectónicas nas Casas-museu em Portugal. (Dissertação de Mestrado, Universidade do Porto, Portugal). Disponível em:

https://sigarra.up.pt/faup/pt/pub_geral.pub_view?pi_pub_base_id=274165

- Navalho, S. S. (2020). Casa-Museu Soledade Malvar. Edifício, Coleção e Inventário. (Dissertação de Mestrado, Universidade do Porto Portugal). Disponível em: https://hdl.handle.net/10216/130664

- Pamplona, F. (1991). Dicionário de Pintores e Escultores Portugueses ou que Trabalham em Portugal. Porto: Livraria Civilização Editora.

- Pearce, S. M. (2003a). Collecting reconsidered. In S. M. Pearce (Ed.), Interpreting Objects and Collections (pp. 193-204). London and New York: Routledge.

- Pearce, S. M. (2003b). Objects as meaning; or narrating the past. In S. M. Pearce (Ed.), Interpreting Objects and Collections (pp. 19-29). London and New York: Routledge.

- Pearce, S. M. (2003c). Thinking about things. In S. M. Pearce (Ed.), Interpreting Objects and Collections (pp. 125-132). London and New York: Routledge.

- Ponte, A. (2007). Casas-museu em Portugal: Teorias e Práticas. (Dissertação de Mestrado, Universidade do Porto, Portugal). Disponível em: https://www.academia.edu/42249970/PONTE_2007__Disserta\%C3\%A7\%C3\%A3o_de_Mestrado

- Ponte, A. (2019). Casas-museu. Entre o conceito e o modelo de ação. Da constituição ao modelo de investigação. In M. J. Monge, Coleção Património a Norte 1. 10 Anos de Reflexão sobre Casas-Museu em Portugal (pp. 19-34). 
Porto: Direção Regional de Cultura do Norte - Ministério da Cultura, Comité Internacional do ICOM - Portugal e DEMIST.

- Prown, J. D. (2003). Mind in matter. An introduction to material culture theory and method. In S. Pearce (Ed.), Interpreting Objects and Collections (pp. 133138). London and New York: Routledge.

- Rede de Museus de Vila Nova de Famalicão (2002). Casa-Museu Soledade Malvar/Roteiro [Brochura]. Vila Nova de Famalicão: Câmara Municipal de Vila Nova de Famalicão.

- Rede de Museus de Vila Nova de Famalicão (2018). Rede de Museus Vila Nova de Famalicão. A Nossa Identidade. O Nosso Futuro [Brochura]. Vila Nova de Famalicão: Câmara Municipal de Vila Nova de Famalicão.

- Rede de Museus de Vila Nova de Famalicão (2019). Definir a missão... da necessidade ao desafio. Ser e Fazer Museu no Século XXI, 1, 49-51.

- Salão Silva Porto (1943). Exposição Retrospectiva e de Homenagem ao Mestrepintor Júlio Ramos. Porto: s.n.

- Universidade Digital/Gestão de Informação (2009). Antigos Estudantes Ilustres da Universidade do Porto - Júlio Ramos. Disponível em: https://sigarra.up.pt/up/pt/web_base.gera_pagina?p_pagina=antigos\%20estud antes\%20ilustres\%20-\%20j\%c3\%balio\%20ramos 


\section{Marta Fontoura Miranda}

mfontouram@gmail.com

Património Escolar do Ensino Primário (PEEP) e coleções nos museus do norte de Portugal. 
Miranda, M. F. (2021). Património Escolar do Ensino Primário (PEEP) e coleções nos museus do norte de Portugal. In P. M. Homem, B. Andrez, G. Soares, \& L. Amaral (Eds.), Ensaios e Práticas em

Museologia (Vol. 10, pp. 108-130). Porto: FLUP/DCTP/MMUS. https://doi.org./10.21747/978-9899082-06-9/102021a7

Resumo

O Património Escolar do Ensino Primário tem vindo a anunciar um estado de emergência, dados os edifícios e materiais abandonados. Como têm sido tratados estes imóveis e objetos? Qual a importância dos objetos na escola? No universo da escola e do seu património - o que tem sido alvo de estudo? Tendo em conta que outrora fizeram parte do nosso dia a dia e de muitas conquistas da sociedade, estarão esses objetos inventariados? Este texto surge na perspetiva do projeto REduF ${ }^{1}$, com uma abordagem interdisciplinar que oferece uma multiplicidade de olhares sobre esta temática. Pretende ser um ponto de partida, de reunião dos trabalhos científicos realizados nos Estabelecimentos do Ensino Superior Público. Permite uma visão diagnóstica e a identificação dos acervos museológicos (a norte de Portugal), auxilia o mapeamento das diversas coleções já acolhidas, contribuindo, assim, para a definição de futuros estudos/projetos.

Palavras-chave: Património Escolar do Ensino Primário; REduF; Mapeamento; Coleções

\section{Nota biográfica}

Marta Miranda é professora, licenciada em Ensino Básico (2001) na Escola Superior de Educação de Bragança, pós-graduada em Administração e Planificação da Educação (2003) na Universidade Portucalense, e mestre em Museologia (2019) pela Faculdade de Letras da Universidade do Porto. Já lecionou nos três níveis do ensino básico e tem gerido o seu tempo entre projetos ligados à museologia e à educação.

\footnotetext{
${ }^{1}$ Raízes da Educação para o Futuro, Fundação para a Ciência e a Tecnologia, referência PTDC/CEDEDG/30342/2017.
}

\section{Abstract}

The School Heritage of Primary Education has been announcing a state of emergency, given the abandoned buildings and materials. How have these properties and objects been treated? What is the importance of objects at school? In the universe of the school and its heritage - what has been the subject of study? Bearing in mind that they were once part of our day-to-day lives and of many achievements of society, are these objects inventoried? This text appears in the perspective of the REduF project, with an interdisciplinary approach that offers a multiplicity of views on this theme. This is intended to be a starting point for the gathering of scientific works carried out in Public Higher Education Establishments. It allows a diagnostic view, and the identification of museum collections (in the North of Portugal), helps to map the various collections already received, thus contributing to the definition of future studies/projects.

Keywords: School Heritage of Primary Education; REduF; Mapping; Collections

\section{Biographical note}

Marta Miranda is a teacher, with a degree in Basic Education (2001) at the Escola Superior de Educação de Bragança, a postgraduate degree in Administration and Planning in Education (2003) at Universidade Portucalense and a master's degree in Museology (2019) from the Faculty of Arts and Humanities of the University of Porto. She has already taught at the three levels of basic education and has managed her time between projects related to museology and education 


\section{Introdução}

A escola apresenta-se como a instituição responsável pelo ensino, presente na maioria dos países num sistema formal de educação. Estes sistemas formaram-se ao longo dos tempos à medida dos sistemas políticos de cada país. No caso de Portugal, regularizase em 1772 - aquando da lei de 6 de novembro. A relação entre o Estado e o Ensino a escola como instituição da comunidade - inicia-se legalmente com a Reforma Pombalina. Desde a sua constituição como instituição pública, sofreu diversas modificações instigadas pela realidade política e económica em vigor. O percurso da escola como instituição surge, no discurso político, sempre associado à necessidade de combater o analfabetismo (Carvalho, 1985). As estratégias de resolução, ao longo dos tempos, orientaram-se pela construção de escolas, criação de postos de trabalho para a instrução e incentivos ou penalizações para a adesão da população. A par das questões ligadas às infraestruturas e recursos humanos, também se assiste a grandes discussões ideológicas, a nível nacional e até internacional, sobre as diferentes metodologias de ensino, organização do espaço escolar - letivo, administrativo e de ócio - estratégias e materiais de auxílio às aprendizagens.

Nos últimos anos, perante uma nova organização da sociedade e novas realidades políticas e económicas, a escola sofre novas modificações, um grande número dos edifícios construídos e vividos são abandonados, dando lugar a novos projetos de arquitetura, novos espaços, novos mobiliários, novos materiais. Toda esta renovação deixa para trás fragmentos do nosso passado.

\section{Património escolar}

O conceito de património tem sido alvo de estudo e diversas reflexões. Perante a lei atual, Lei n.․ 107/2001, que estabelece as bases da política e do regime de proteção e valorização do património cultural, o património escolar está diretamente ligado à importância que os objetos e edifícios apresentavam, por questões de inovação 
pedagógica ou saúde pública. A implementação da escola pública inclui preocupações constantes pelos espaços e sua organização, pelo mobiliário e pelos materiais didáticos, por parte de pedagogos, políticos e professores. Os bens imóveis e móveis eram considerados de extrema importância para o desenvolvimento das atividades letivas e processos educativos como referem Mogarro et al. (2010):

(...) os discursos educativos demonstram que os intelectuais e pedagogos, assim como os responsáveis pela política educativa, se encontravam bem informados das modernas correntes da pedagogia, circulavam internacionalmente em eventos de referência (congressos, exposições universais) e tinham consciência da necessidade de intervenção para alterar esta situação. Um processo de regeneração impunha-se para o país e ele devia assentar na difusão da instrução e em construções escolares que assegurassem o desenvolvimento físico, intelectual e moral das jovens gerações e da população em geral (p. 94).

Este conjunto de bens materiais e imateriais fala por si, conta como se ensinava, que estratégias se utilizavam; representa um testemunho com valor de civilização. Numa abordagem à bibliografia relacionada com o tema surgem termos como os de: cultura material escolar; materialidade escolar; cultura material da escola; ou materialidade da cultura escolar. As diferentes expressões, semelhantes, remetem para significados também eles semelhantes.

\section{Mapeamento de trabalhos científicos relativos a Património Escolar do Ensino Primário (PEEP)}

\subsection{Metodologia}

Todo o trabalho desenvolvido pela comunidade científica, que tem vindo a organizarse, dentro e fora das nossas fronteiras, propondo discussões que têm desenvolvido relações entre as diferentes áreas científicas, promovendo a interdisciplinaridade, utilizando uma maior diversidade de fontes, nos permite estruturar novas abordagens 
muito importantes para o campo específico do Património Escolar (Pintassilgo, 2007). Partindo do princípio que reconhecer, inventariar e caracterizar os trabalhos realizados por outros investigadores, oferece uma visão alargada do tema, procedeu-se a um levantamento dos trabalhos científicos (teses e dissertações) desenvolvidos nas universidades públicas portuguesas.

O estudo (Miranda, 2019) foi realizado tendo como base a abordagem que Fontal e Ibañez-Etxeberria (2017) apresentaram a propósito da investigação de Educação Patrimonial em Espanha. Esta, definiu-se através de indicadores de alto impacto, utilizando marcos de investigação científica padronizados para todas as áreas do conhecimento e homólogos a outros contextos. Para tal, consideraram a realização de teses e dissertações, o desenvolvimento de projetos investigação competitivos e artigos científicos.

Neste caso, o foco da investigação direcionou-se para a produção científica de teses e dissertações realizadas nas universidades públicas portuguesas, do tema em causa, definindo-as como os indicadores de alto impacto, permitindo, assim, identificar as linhas de investigação que se têm estudado, estabelecer genealogias de pesquisa que refletem a evolução da área e incitar a futuras linhas de investigação.

Para estruturar a investigação definiram-se quatro etapas: definição de descritores (I); realização de pesquisas e construção de uma base de dados (II); criação de categorias e análise de dados (III); e conclusões (IV).

O processo de investigação iniciou-se pela construção de descritores de pesquisa. Identificaram-se as áreas de produção científica que poderiam abordar o objeto de estudo - PEEP - e definiram-se os descritores temáticos através de pesquisa de palavras relacionadas com o contexto, de forma a abranger o património material (móvel e imóvel) e imaterial relacionado com o ensino primário (Fontal \& IbañezEtxeberria, 2017). 
Após a identificação das quatro áreas temáticas de produção científica (Património, Museologia, Antropologia e História) e a identificação de cinco descritores temáticos (ensino primário, memórias escolares, edifícios escolares, material escolar e material didático), estabeleceu-se uma conexão entre os mesmos, definindo os descritores de pesquisa (Tab. 1).

Tab. 1 - Quantificação nos descritores de pesquisa

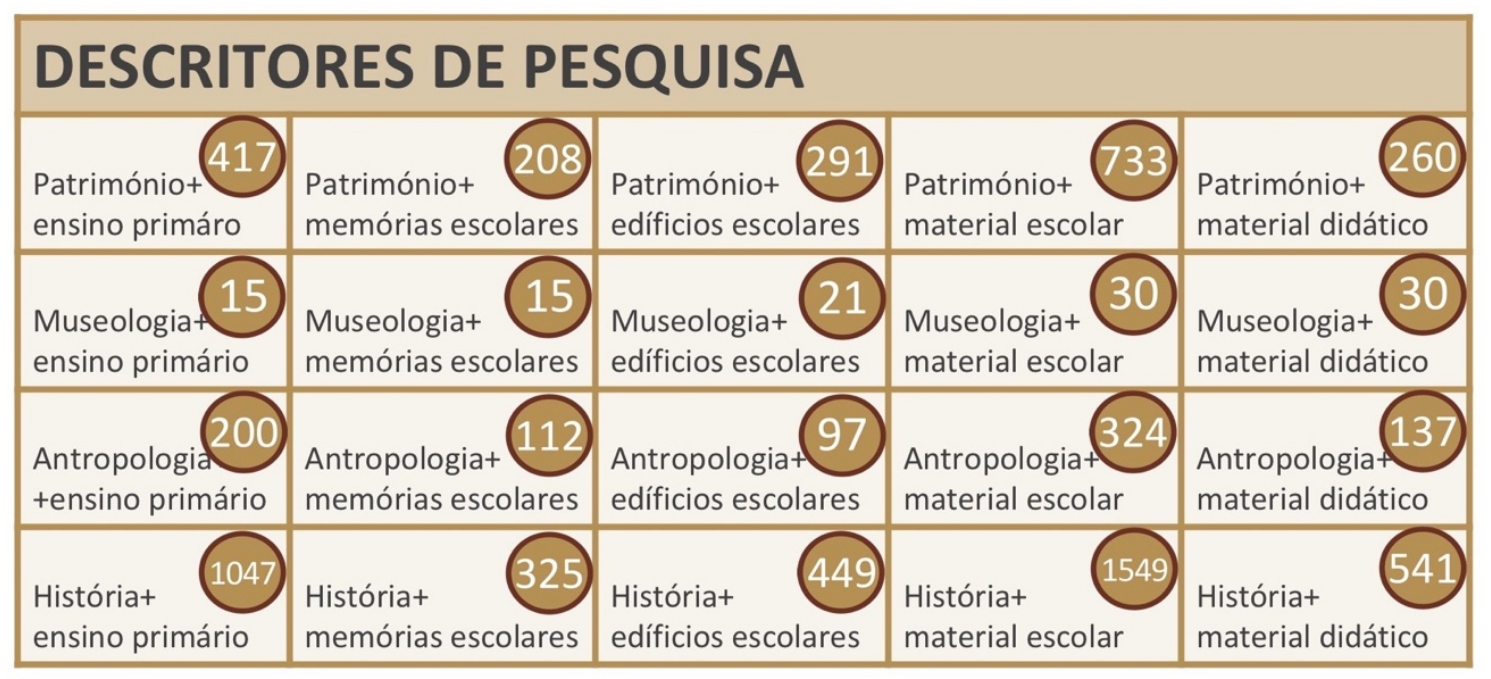

As pesquisas foram realizadas no Repositório Científico de Acesso Aberto em Portugal, com base nos descritores de pesquisa definidos anteriormente e a construção de uma base de dados no Excel com a informação: Autor; Título; Palavras-chave; Resumo; Ano; URL; Orientador e Instituição.

O PEEP é uma área bastante específica e não se definiram balizas cronológicas, para não descartar trabalhos mais antigos. Articularam-se quatro áreas de produção científica, na perspetiva de reunir a visão de diferentes disciplinas que podem ir ao encontro do tema. A dimensão da amostra recolhida (Tab. 1), foi enorme. Se, por um lado, muitos dos trabalhos surgiam em mais do que um descritor de busca, por outro, muitos nada tinham a ver com o tema.

Tendo em conta o tamanho da amostra, criou-se uma coluna na base de dados que reunisse os diferentes descritores que se associavam ao mesmo trabalho. Após este 
procedimento a amostra diminuiu consideravelmente, para menos de metade. De seguida, construiu-se um quadro que ajudasse a organizar o trabalho por categorias, como podemos observar na Fig. 1.

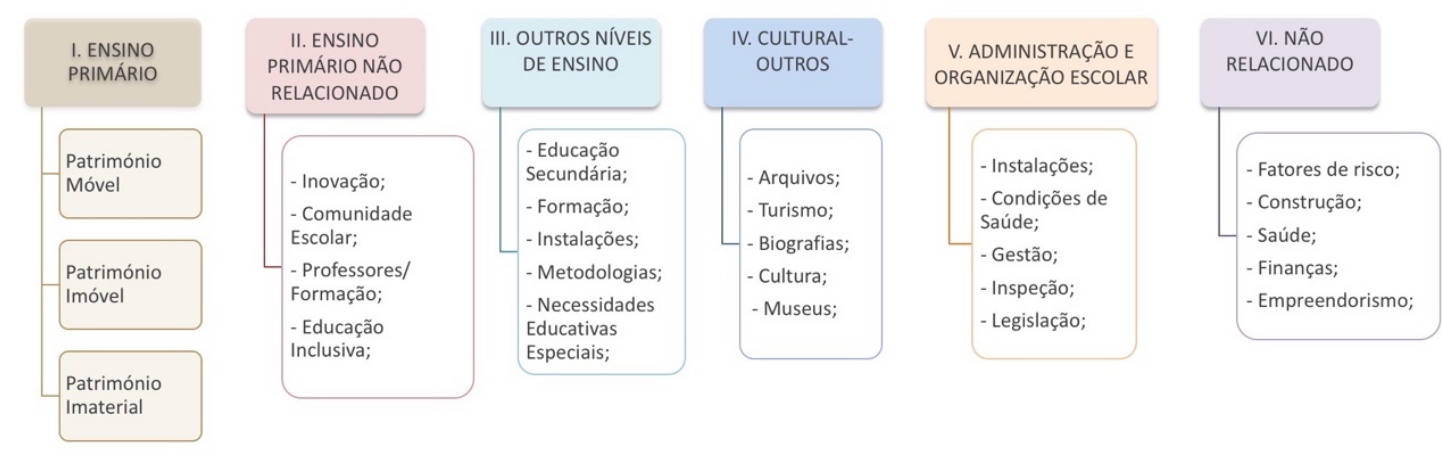

Fig. 1 - Categorias para a organização da base de dados.

Procedeu-se a uma análise de conteúdo a partir do título, palavra-chave e resumos, organizando a amostra pelas categorias definidas.

Com um universo consideravelmente mais pequeno, construiu-se uma listagem dos elementos agrupados na categoria Ensino Primário com relação com o Património Móvel, Imóvel e Imaterial. Para análise dos mesmos, descarregaram-se os respetivos trabalhos para consulta mais profunda. Conseguiu-se, finalmente, a amostra pretendida - uma base de dados com os trabalhos científicos (dissertações e teses) realizados nas universidades públicas portuguesas sobre o PEEP com um universo de 24 trabalhos (Janeirinho, 2003; António, 2004; Carvalho, 2004; Machado, 2004; Pimenta, 2006; Reis, 2006; Candeias, 2007; Mendes, 2008; Palma, 2008; Santos, 2008; Pinto, 2009; Olaio, 2011; Rodrigues, 2012; Faustino, 2013; Feteira, 2013; Nogueira, 2014; Brites, 2015; Neto, 2015; Gama, 2016; Pereira, 2017; Pinto, 2017; Proença, 2017; Teixeira, 2018; Vieira, 2018). 


\subsection{Resultados e discussão}

Quando se organizam os dados cronologicamente para conhecer a sua evolução temporal, verificamos que a primeira data que surge é 2003, enquadrando a produção científica na área num intervalo de 16 anos. Neste período, os valores mantiveram-se bastante constantes, sem grandes variações: entre 0 e 3 trabalhos científicos por ano.

Relativamente às instituições onde decorreram os respetivos trabalhos de investigação (Fig. 2), podemos observar que a Universidade de Lisboa (29\%) e a Universidade do Porto (25\%), obtiveram um número mais elevado, o que se pode relacionar com os projetos desenvolvidos nessas mesmas universidades.

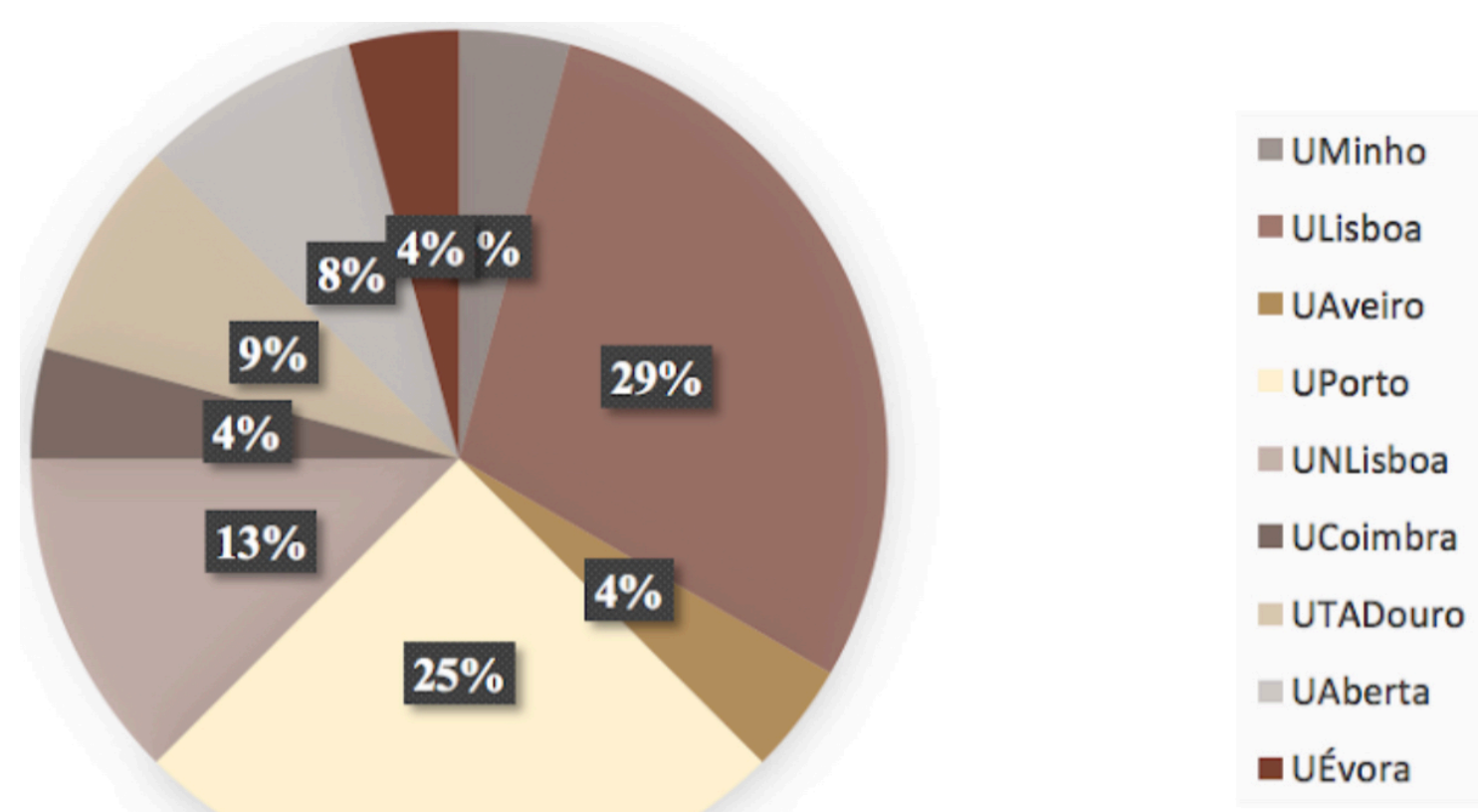

Fig. 2 - Instituições de ensino superior associadas aos trabalhos de investigação.

Na perspetiva de analisar a amostra face aos descritores de pesquisa, podemos concluir que o descritor D1 História+Ensino Primário reúne 11 dos trabalhos de 
investigação, representando $45,8 \%$ da amostra, o que demonstra que a área que tem desenvolvido mais trabalho sobre o tema é, sem dúvida, a da História. O descritor que mais se aproximou foi o A4 - Património+Material Escolar com 5 dos trabalhos de investigação (20\%).

Verifica-se que $61 \%$ dos trabalhos surgem em apenas 1 descritor, $26 \%$ em 2 descritores, $9 \%$ em três descritores e $4 \%$ com 5 descritores, o que significa que $39 \%$ dos trabalhos surgem em mais do que um descritor, ou seja, os trabalhos representativos da amostra já têm uma abordagem transdisciplinar significativa.

A amostra apresenta um conjunto de trabalhos com abordagens distintas. A transdisciplinaridade presente em alguns dos estudos analisados propõe uma nova organização de dados, tendo em conta as pesquisas realizadas. A divisão entre património material móvel, património material imóvel e património imaterial é de grande importância, pois permite verificar e quantificar qual o tipo de património que tem suscitado mais curiosidade aos investigadores portugueses. Para tal, associou-se um conjunto de palavras-chave a cada uma das categorias, como se pode observar na Fig. 3.
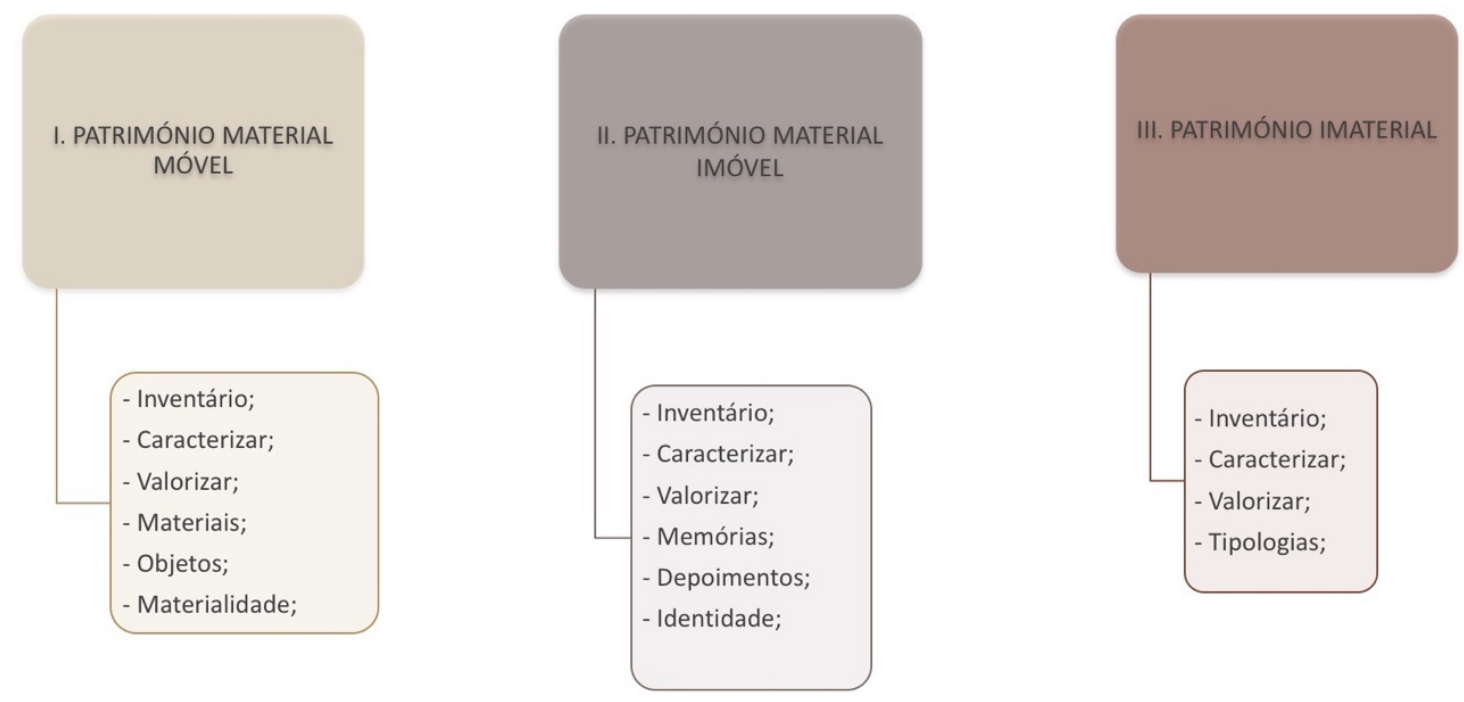

Fig. 3 - Palavras-chave definidas para cada categoria. 
A organização dos trabalhos nas três categorias apresentadas não foi direta em todos os casos, pois alguns apresentam referências a diferentes categorias em simultâneo. Nesses casos, optou-se por os adicionar à categoria central do estudo.

A categoria do Património Material Móvel (5) reuniu o menor número de trabalhos, correspondendo a metade dos trabalhos referentes ao Património Imaterial (10), em número próximo do Património Material Imóvel (9).

Dos 24 trabalhos de investigação, dos 5 referentes ao Património Material Móvel, 2 relacionam-se com mobiliário, 2 com manuais e 1 com os materiais associados ao ensino da matemática.

O conjunto referente ao Património Material Imóvel relaciona-se com diferentes tipologias dos edifícios escolares (Plano dos Centenários); edifícios escolares de determinada região e novos usos de edifícios escolares.

E, por último, os que surgiram em maior número, da categoria Património Imaterial, evocam a memória.

Os diferentes trabalhos científicos e os diferentes projetos desenvolvidos, uns finalizados outros interrompidos devido às dificuldades económicas e políticas, apresentam já um trabalho significativo nesta área. Hoje quando falamos de património educativo reunimos já um conjunto de livros editados, muitos artigos apresentados em eventos científicos, um número significativo de objetos salvaguardados, inventariados e divulgados e uma ligação transnacional com equipas que partilham as mesmas preocupações (Mogarro \& Namora, 2015).

No percurso científico e prático, os projetos desenvolvidos e levados mais além são diminutos no que se relaciona com o ensino primário. Apesar de algumas tentativas através de projetos, ainda pouco se vê na área da materialidade. A base de dados da Secretaria-Geral/Ministério da Educação (SG/ME), que tem como competência a valorização, preservação e divulgação do património histórico do ensino e da 
educação, não apresenta objetos diretamente ligados ao ensino primário no seu inventário. Os grandes projetos analisados dão grande destaque ao ensino secundário, o que faz pensar - em que estado de conservação e estudo se encontra o património ligado ao ensino primário?

O número de edifícios do ensino primário, até ao ano 2000, era muito elevado e geograficamente disperso. Hoje, com as novas políticas educativas, grande parte dos edifícios foi abandonada e muitos foram incumbidos de outras utilizações. Os objetos, muitos foram destruídos e outros salvaguardados por professores, associações e municípios mais sensíveis à sua salvaguarda, mas encontram-se apenas reunidos na expectativa de serem agrupados a coleções organizadas, inventariados e envolvidos num estudo de coleção que descreva o seu percurso.

A escola hoje apresenta-se com uma estrutura administrativa muito diferente da que se conhecia até um passado muito próximo - os agrupamentos ou mega agrupamentos são as estruturas responsáveis pela gestão e administração deste espaço qualificado. A administração e gestão de um agrupamento inclui os diferentes níveis de ensino, não se cinge apenas ao ensino secundário! Não deveriam os agrupamentos responsabilizar-se pelo seu património? Não deveriam continuar o inventário iniciado com o ensino secundário com a SG/ME?

O PEEP deveria ser reunido nos seus contextos, inventariado segundo uma terminologia comum e devidamente estudado numa dinâmica interdisciplinar, para, assim, se criarem narrativas criativas baseadas na realidade e os públicos usufruírem da sua herança educativa (Felgueiras, 2017). 


\section{PEEP em coleções de museus do norte de Portugal}

\subsection{Metodologia}

Compreender o percurso dos objetos e as suas diferentes funções, tal como a manipulação e diferentes abordagens das sociedades a esses mesmos objetos, é de grande importância na relação que hoje se pode desenvolver com os mesmos.

A localização e classificação das respetivas coleções relacionadas com o património escolar permite criar diálogos entre as instituições (escola/museu e museu/museu), de forma a contribuir para a sua preservação, inventariação, interpretação e divulgação.

Ao longo dos tempos, a inovação pedagógica e os novos modelos de ensino deram lugar a edifícios, materiais e estratégias educativas, fragmentos da cultura escolar que definem o património escolar.

Os objetos que habitam as escolas têm tido duas funções: apoiar o desenvolvimento das aprendizagens (materiais didáticos) ou apoiar a vivência do espaço (equipamentos e mobiliário). Para além destas utilidades (pedagógica e utilitária), permitem uma exploração museológica científica e histórica (Possamai e Paz, 2017). Se, por um lado, constituem património estão diretamente ligados ao museu, como instituição responsável pelo património da humanidade, por outro, estão também ligados à escola, como seu espaço de vida.

As ações promovidas pelos diferentes governos em torno do património escolar têmse centralizado no ensino secundário e industrial, em que os objetos ficam na tutela das respetivas instituições escolares. Outros foram reunidos de forma a salvaguardálos pelas comunidades que, em alguns casos, com o apoio da comunidade científica e dos municípios, através da implementação de alguns projetos encontram-se sob a tutela de museus ${ }^{1}$, já existentes ou criados para esse fim - o da salvaguarda do PEEP.

1 Museu Pedagógico de Lamego; Museu Escolar de Marrazes; Museu Escolar Oliveira Lopes; Museu da Escola, Paredes. 
Para melhor conhecimento do PEEP recolhido foi necessário realizar um levantamento identificando as instituições museológicas com coleções relacionadas com o PEEP, localizando o que existe e em que estado de inventário se encontra, constituindo-se como um roteiro e uma base de dados.

Tendo em conta a localização geográfica do Centro Interdisciplinar Transfronteiriço e Inter-regional de Memória da Educação (CITRIME) definiu-se a zona geográfica do estudo como sendo o norte de Portugal.

A investigação desenvolveu-se em três fases:

- Planeamento - Identificação e organização de fontes; desenvolvimento dos instrumentos de recolha de dados: questão de partida, inquéritos por questionário online; design e reprodução do inquérito por questionário online; pré-teste dos inquéritos por questionário online;

- Trabalho de campo - Envio da pergunta de partida; envio dos inquéritos por questionário online;

- Análise dos resultados - Validação dos dados; análise, tratamento e discussão dos dados.

A comunicação com os museus iniciou-se a partir de uma base de dados previamente organizada por Liliana Aguiar - Levantamento dos Museus do Norte de Portugal. Com o objetivo de localizar coleções/objetos, colocou-se a questão “O museu contém coleções relacionadas com o Património Escolar do Ensino Primário?" Também se pretendia saber:

- Que tipologias estavam presentes nos acervos destes museus, que pudessem estar relacionadas com o Património Escolar;

- O seu estado de inventário, documentação e estudo;

- E se organizaram exposições e/ou publicação, nomeadamente em catálogo. 
O inquérito por questionário foi aplicado utilizando o formulário Google, pois reunia um conjunto de questões de resposta direta e cada instituição poderia preenchê-lo no momento mais indicado e reenviá-lo. Para construção da questão: “Que tipologias estavam presentes nos acervos dos museus, relacionadas com o Património Escolar?" utilizou-se a terminologia utilizada no projeto de inventariação do património escolar da SG/ME.

O trabalho de campo iniciou-se com o envio de um e-mail a todos os museus dando a conhecer o estudo e o pedido de apoio a este levantamento. Após os diversos contatos com as instituições museológicas procedeu-se à análise dos dados recolhidos.

\subsection{Resultados e discussão}

Do universo de 160 instituições museológicas, 9\% não respondeu (apesar dos múltiplos contatos), $77 \%$ não tem coleções relacionadas com o PEEP e $14 \%$ tem coleções relacionadas com o PEEP, distribuído pela área geográfica apresentada na Fig. 4.

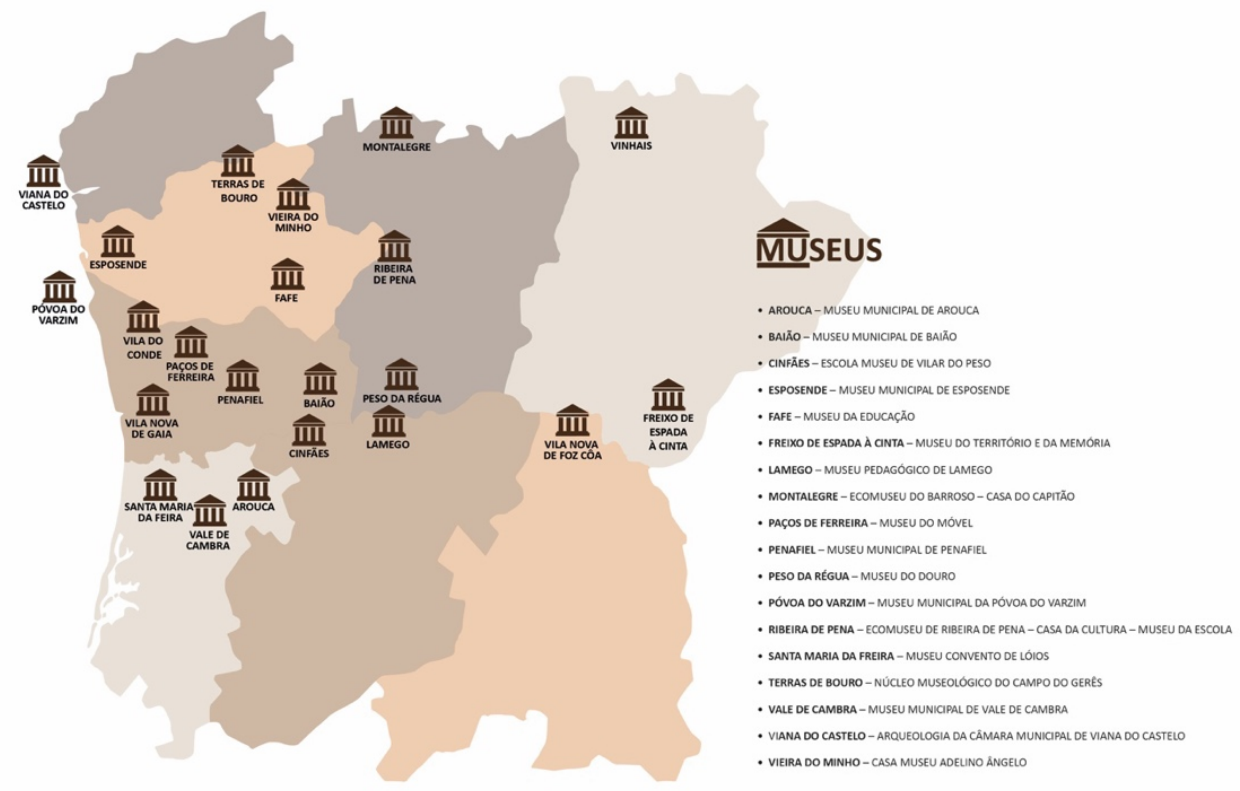

Fig. 4 - Localização dos museus do norte de Portugal com coleções relacionadas com o PEEP. 
Entre os museus do norte de Portugal detentores de coleções relacionadas com o PEEP, verifica-se que apenas um, o Museu do Douro, não é tutelado pelo Município, o que demonstra bem o papel que os municípios tiveram aquando do encerramento das escolas primárias.

Relativamente às coleções sinalizadas pelos museus inquiridos, conseguiram-se identificar as tipologias presentes em cada espaço museológico. As mais presentes na maioria das coleções são: mobiliário; sólidos geométricos e quadros parietais relacionados com a geografia.

No que se refere à pergunta associada às exposições "Quantas exposições sobre o tema Património Escolar - Escola Primária foram organizadas no museu?" as respostas demonstram que a maioria (57\%) dos museus inquiridos já tinha organizado uma exposição sobre o tema, $26 \%$ que não organizou nenhuma exposição e $17 \%$ organizou mais do que uma exposição.

Embora o número de exposições seja significativo, não foi possível caracterizar o tipo de exposição através dos questionários. Uma vez que o número de museus da amostra (17) não é elevado, procedeu-se a uma visita às respetivas páginas web de cada uma das instituições, com o objetivo de caracterizar o tipo de exposição e reforçar a recolha de dados. Para tal, definiram-se as tipologias indicadas na Tab. 2.

Tab. 2 - Tipo de exposição e respetivas características.

\begin{tabular}{cc}
\hline TIPOLOGIA & \multicolumn{1}{c}{ CARACTERISTICAS } \\
\hline MUSEU TEMÁTICO & QUANDO O PATRIMÓNIO ESCOLAR DEFINE A MISSÃO DO MUSEU \\
\hline NÚCLEO DE EXPOSIÇÃO PERMANENTE & $\begin{array}{l}\text { QUANDO NA EXPOSIÇÃO PERMANENTE EXISTE UM NÚCLEO RESERVADO } \\
\text { AO PATRIMÓNIO ESCOLAR DO ENSINO PRIMÁRIO }\end{array}$ \\
\hline EXPOSIÇÃO TEMPORÁRIA & QUANDO É REALIZADA ALGUMA EXPOSIÇÃO DE CARÁCTER TEMPORÁRIO
\end{tabular}


Após a visita às páginas web dos 17 museus que já tinham organizado mais do que uma exposição, pode concluir-se que cinco $^{2}$ dos museus da amostra são museus temáticos, cuja missão se relaciona diretamente com o PEEP, e um³ tem um núcleo na exposição permanente. A página web dos restantes não permitiu tirar conclusões.

Relativamente aos catálogos existentes sobre o tema, nos museus da amostra, apenas um respondeu positivamente, Museu do $\mathrm{Móvel}$ mas quando visitado ${ }^{4}$ e pedido, não estava disponível, no momento.

\section{Considerações finais}

A investigação partilhada foi desenvolvida com o intuito de localizar o Património Escolar do Ensino Primário e averiguar a forma como este tem sido abordado, contribuindo para os objetivos desenhados pelo projeto de investigação ReduF. Para tal, foi realizada uma síntese sobre o percurso do referido nível de ensino e realizada uma análise cuidada de alguns conceitos relacionados com o património escolar.

Os objetos desempenham uma função num determinado período de tempo, função definida logo no momento da sua criação. Contudo, mais tarde, essa mesma função é substituída. Por isso mesmo, os objetos passam a ilustrar um passado, são vistos como uma fonte que, quando analisada, promove a compreensão do desenvolvimento da escolaridade em massa e, juntamente com outras, define a história das sociedades. Os objetos escolares não contam apenas a história da escola, eles contam a história da sociedade e, quando interpretados, indicam relações dos sujeitos com as coisas. As interpretações devem ser realizadas tendo em conta o tempo, mas também o espaço,

\footnotetext{
2 Escola Museu de Vilar do Peso (Cinfães); Museu da Educação (Fafe); Museu Pedagógico de Lamego (Lamego) e Ecomuseu de Ribeira de Pena: - Casa da Cultura - Museu da Escola (Ribeira de Pena); Museu da Escola (Paredes). 3 Museu do Móvel (Paços de Ferreira).

4 Visita ao espaço realizada no dia 24.08.2019.
} 
pois a escola define um contexto de extrema importância na caracterização de uma região.

O património escolar, definido através da cultura material e imaterial da escola, constitui uma memória, individual e coletiva. Uma das principais formas de a preservar é construir conhecimento sobre ela - reunir, conservar, inventariar e interpretar é imprescindível para a salvaguarda e a valorização do Património. O conhecimento da identidade e a cultura de uma comunidade constituem um suporte de identificação, indispensável para o equilíbrio do ser humano. Quando se foca o património escolar na dimensão da herança educativa, ele ocupa um espaço de pertença, o qual está diretamente ligado à responsabilidade de cuidar (Costa, 2006).

No âmbito do projeto REduF, a criação do espaço interdisciplinar CITRIME apresentase como um lugar de preservação da memória da educação, com uma intervenção de caráter científico, tanto na preservação como na divulgação. O mapeamento realizado do trabalho científico e da localização e a caracterização das coleções nos museus do norte de Portugal são um ponto de partida.

Identificar e conhecer, não só o trabalho científico (teses e dissertações) mas também projetos científicos relacionados com o tema nas diferentes áreas, é de extrema importância para a construção do estado de arte de futuros trabalhos de investigação sobre o tema.

Localizar as coleções nas instituições museológicas e as respetivas tipologias é fundamental na abordagem museológica, salientando que a museologia, enquanto disciplina, tem como propósito recolher, inventariar, investigar, conservar e divulgar de forma a salvaguardar e valorizar o património da humanidade.

A vitalidade do tema está bem presente, visto que regressou no século XXI. Face ao estudo realizado, é notório o interesse crescente pelas questões relacionadas com o património escolar. 
Aquando do encerramento das escolas primárias distribuídas pelo território, cuja transferência foi feita para os centros escolares, os edifícios e materiais ficaram abandonados. A população teve um papel de extrema importância para com o PEEP, pois grande parte dos objetos recolhidos e salvaguardados partiu, na maioria dos casos, de iniciativas em nome individual.

As universidades têm vindo a desenvolver projetos relacionados, cada vez mais interdisciplinares, mas, muitas vezes, por falta de meios financeiros e pouca abertura política, não têm chegado ao desenvolvimento esperado.

O Ministério da Educação tem vindo já a desenvolver algumas iniciativas relacionadas com a salvaguarda e valorização do Património Escolar do Ensino Secundário, todavia tal não engloba o Património Escolar do Ensino Primário. Atualmente, as escolas secundárias estão sob a administração dos Agrupamentos de Escolas e o seu trabalho desenvolvido pode ser estendido aos outros níveis de ensino.

$\mathrm{Na}$ área dos museus este património está salvaguardado, mas com necessidade de uma política museológica orientada. Os museus têm acolhido algumas coleções e, tendo em conta as suas responsabilidades, quer para com o património que lhe é confiado quer para com a comunidade, devem criar condições de inventariação, investigação/interpretação e gestão destas coleções, para assim definirem um plano de valorização e divulgação.

As bases de dados realizadas pretendem oferecer um conjunto de dados significativos para o desenvolvimento de projetos na área do PEEP.

Tal como os estudos científicos requerem estudos interdisciplinares da sociedade de hoje, também a operacionalização de projetos requer parcerias por parte das instituições. 


\section{Referências}

- António, M. J. (2004). O Que Ficou na Memória: Os Castigos Corporais na Escola Primária: 1900-1960. (Dissertação de Mestrado, Universidade de Lisboa, Lisboa). Disponível em: http://hdl.handle.net/10451/27465

- Brites, R. C. (2015). A Tecnologia como Mediadora das Memórias Escolares: o Museu Escolar. (Dissertação de Mestrado, Universidade do Porto, Porto). Disponível em: http://hdl.handle.net/10216/81815

- Candeias, R. P. (2007). Contributo para a história das inovações no ensino da matemática no primário: João António Nabais e o ensino da matemática no Colégio Vasco da Gama. (Dissertação de Mestrado, Universidade de Lisboa, Lisboa). Disponível em: http://hdl.handle.net/10451/1199

- Carvalho, J. M. (2004). A Indústria do Mobiliário Escolar em Paços de Ferreira: O Caso da Fábrica Albino de Matos, Pereira \& Barros. Porto: Universidade do Porto.

- Carvalho, R. (1985). História do Ensino em Portugal. Desde a Fundação da Nacionalidade até ao fim do Regime de Salazar-Caetano. Lisboa: Fundação Calouste Gulbenkian.

- Costa, R. J. (2006). Resgatar a memória do futuro da escola. A Página da Educação, 153. Disponível em: https://www.apagina.pt/?aba=7\&cat=153\&doc=11373\&mid=2

- Faustino, J. P. (2013). Estado Novo, Arquitetura e Ensino Primário: As Escolas tipo Douro de Rogério de Azevedo (1935), no Distrito do Porto, e a sua Evolução até ao Plano das Centenárias (1944). (Dissertação de Mestrado, Universidade de Coimbra, Coimbra). Disponível em: http://hdl.handle.net/10316/35989

- Feteira, J. S. (2013). O Plano dos Centenários - As Escolas Primárias (19411956). (Dissertação de Mestrado, Universidade Nova de Lisboa, Lisboa). Disponível em: http://hdl.handle.net/10362/1134 1 
- Fontal, O., \& Ibañez-Etxeberria, A. (2017). La investigatión en Educatión Patrimonial. Evolución y estado actual a través del análisis de indicadores de alto impacto. Revista de Educación, 375(8), 184-214. DOI: 10.4438/1988-592XRE-2016-375-340

- Gama, A. (2016). O Plano dos Centenários. (Dissertação de Mestrado, Universidade Nova de Lisboa, Lisboa). Disponível em: http://hdl.handle.net/10400.6/5089

- Janeirinho, L. (2003). Dar Voz aos Objectos: Contributos dos Documentos de Vida na Construção de um Museu de Escola. (Dissertação de Mestrado, Universidade de Évora, Évora). Disponível em: http://hdl.handle.net/10174/15292

- Lei n. 107/2001 (2001). Diário da República. I série A, n. 209. https://dre.pt/dre/analise-juridica/lei/107-2001-629790

- Machado, M. F. (2004). Maneiras de Sentar: Contributo Para a História das Carteiras Escolares do Ensino Primário em Portugal: 1835-1970. (Dissertação de Mestrado, Universidade de Lisboa, Lisboa). Disponível em: http://hdl.handle.net/10451/30669

- Mendes, A. (2008). A Construção do Parque Escolar do Ensino Primário na Cidade de Portalegre: Uma Perspectiva Através dos Documentos Locais. (Dissertação de Mestrado, Universidade de Lisboa, Lisboa). Disponível em: http://hdl.handle.net/10451/765

- Mogarro, M. J., Gonçalves, F., Casimiro, J., \& Oliveira, I. (2010). Inventário e digitalização do património museológico da educação - um projeto de preservação e valorização do património educativo. História da Educação, 14(30), 153-179. Disponível em: https://repositorio.ul.pt/handle/10451/12310

- Mogarro, M. J., \& Namora, A. (2015). Educação e Património Cultural Escolas, Objetos e Práticas. Lisboa: Edições Colibri. 
- Miranda, M. (2019). Património Escolar do Ensino Primário e Coleções nos Museus do Norte de Portugal. (Dissertação de Mestrado, Universidade do Porto, Porto). Disponível em: https://hdl.handle.net/10216/124644

- Neto, A. (2015). Os Manuais do Ensino Primário e Elementar e a Inculcação dos Valores do Estado Novo. (Dissertação de Mestrado, Universidade Nova de Lisboa, Lisboa). Disponível em: http://hdl.handle.net/10362/15980

- Nogueira, L. P. (2014). Projectar uma Infância Portuguesa. Os Espaços da Educação Segundo Raúl Lino. (Dissertação de Mestrado, Universidade do Porto, Porto). Disponível em: http://hdl.handle.net/10216/77406

- Olaio, T. R. (2011). A Rede do Ensino Primário em Águeda Durante o Estado Novo. (Dissertação de Mestrado, Universidade de Aveiro, Aveiro). Disponível em: https://ria.ua.pt/handle/10773/8041

- Palma, H. (2008). A Matemática na Escola Primária: Um Olhar Sobre o Ensino da Matemática nas Escolas Portuguesas Desde o Final do Século XIX até à Década de 70 do Século XX. (Dissertação de Mestrado, Universidade de Lisboa, Lisboa). Disponível em: http://hdl.handle.net/10451/766

- Pereira, M. L. (2017). A Escola Portuguesa ao Serviço da Nação: Discursos e Práticas de Orientação e Disciplina do Professorado Primário (1926-1956). (Tese de Doutoramento, Universidade Aberta, Lisboa). Disponível em: http://hdl.handle.net/10400.2/6785

- Pimenta, P. P. (2006). A Escola Portuguesa: Do "Plano dos Centenários" à Construção da Rede Escolar no Distrito de Vila Real. (Dissertação de Mestrado, Universidade do Minho, Braga). Disponível em: http://hdl.handle.net/1822/6973

- Pintassilgo, J. (2007). História do currículo e das disciplinas escolares: balanço da investigação portuguesa. In J. Pintassilgo, L. A. Alves, L. G. Correia \& M. L. Felgueiras (Eds.), A História da Educação em Portugal: Balanço e Perspectivas (pp.1-27). Porto: Edicões ASA. 
- Pinto, M. A. (2017). O Património Oral nas Práticas Educativas do PLNM em Timor-Leste. (Dissertação de Mestrado, Universidade Aberta, Lisboa). Disponível em: http://hdl.handle.net/10400.2/6602

- Pinto, P. (2009). O Ensino Primário e seus Valores em Portugal, de 1807 até 1928, através dos Manuais Escolares. (Dissertação de Mestrado, Universidade de Lisboa, Lisboa). Disponível em: http://hdl.handle.net/10451/2228

- Possamai, Z., \& Paz, F. R. (2017). Pesquisar e ensinar: considerações sobre museus escolares de ciências, Brasil e Argentina. In M. Granato, E. S. Ribeiro \& B. M. Araujo (Eds.), Cadernos do Patrimônio da Ciência e Tecnologia: Instituições, Trajetórias e Valores (pp. 283-308). Rio de Janeiro: Museu de Astronomia e Ciências Afins.

- Proença, A. C. (2017). O Jogo Popular como Meio de Educação e de Intervenção Comunitária. (Dissertação de Mestrado, Universidade Aberta, Lisboa). Disponível em: https://1library.org/document/q73|83ry-jogo-popularinfantil-como-meio-educacao-intervencao-comunitaria.html

- Reis, F. C. (2006). A Pedagogia Moderna: O Espaço, os Instrumentos, as Práticas: 1860-1960. (Dissertação de Mestrado, Universidade de Lisboa, Lisboa). Disponível em: http://hdl.handle.net/10451/32482

- Rodrigues, G. M. F. L. (2012). O Património Escolar e Novos Usos Turísticos - A Recuperação para Unidades de Alojamento no Concelho de Ponte de Lima. (Dissertação de Mestrado, Universidade do Porto, Porto). Porto: Universidade do Porto. Disponível em: http://hdl.handle.net/10216/66403

- Santos, R. M. F. M. (2008). Espaços de Memória em Mação, Construção Socialmente Participada de Perspetivas da Cultura Material. (Dissertação de Mestrado, Universidade de Trás-os-Montes e Alto Douro, Vila Real). Disponível em: https://catalogo.biblioteca.utad.pt/cgi-bin/koha/opacdetail.pl?biblionumber $=59307$

- Teixeira, P. A. M. (2018). Pensar Experienciando: Conceção de Práticas Educativas num Centro de Memória. (Dissertação de Mestrado, Universidade do Porto, Porto). Disponível em: https://hdl.handle.net/10216/113597 
Miranda, M. F. (2021). Património Escolar do Ensino Primário (PEEP) e coleções nos museus do norte de Portugal. In P. M. Homem, B. Andrez, G. Soares, \& L. Amaral (Eds.), Ensaios e Práticas em Museologia (Vol. 10, pp. 108-130). Porto: FLUP/DCTP/MMUS. https://doi.org./10.21747/978-9899082-06-9/102021a7

- Vieira, S. S. (2018). O Lugar da Herança Cultural no Desenvolvimento Local: $A$ Experiência de Pensar com os Atores Sociais um Centro de Memória da Educação. (Dissertação de Mestrado, Universidade do Porto, Porto). Disponível em: https://repositorio-aberto.up.pt/handle/10216/116807 


\section{Bárbara Andrez}

barbaraandrez@gmail.com

Infocomunicação em museus: uma reflexão à luz do paradigma da complexidade de Edgar Morin. 
Andrez, B. (2021). Infocomunicação em museus: uma reflexão à luz do paradigma da complexidade de Edgar Morin. In P. M. Homem, B. Andrez, G. Soares, \& L. Amaral (Eds.), Ensaios e Práticas em

Museologia (Vol. 10, pp. 131-141). Porto: FLUP/DCTP/MMUS. https://doi.org./10.21747/978-9899082-06-9/102021a8

Resumo

A presente reflexão pretende introduzir, de forma sucinta, uma abordagem sistémica da infocomunicação no contexto das instituições museológicas. Partindo da premissa que as ações museológicas e os mecanismos expositivos não são atividades neutras, mas relevantes para a representação e comunicação das relações que se estabelecem entre sociedades e tempos a partir dos objetos expostos, reflete-se sobre a sua importância e adequação. Alicerçados no paradigma da complexidade de Edgar Morin, procede-se a um primeiro enunciado de possíveis fatores - internos e externos - que influenciam os processos de informação e de comunicação dentro e fora dos museus, bem como a identificação de algumas relações e potenciais eixos de ação.

Palavras-chave: Complexidade; Infocomunicação; Fatores de influência; museus

\section{Nota biográfica}

Bárbara Andrez é licenciada em Estudos Teatrais pela Escola Superior de Música e de Artes do Espetáculo (ESMAE), mestre em Criação Artística

Contemporânea pela Universidade de Aveiro Departamento de Comunicação e Arte (UA/DeCA) e mestre em Museologia pela Faculdade de Letras da Universidade do Porto (FLUP). Atualmente é bolseira de investigação FCT/CITCEM no programa doutoral em Informação e Comunicação em Plataformas Digitais, curso conjunto da FLUP e UA/DeCA. Trabalhou como técnica superior de ação cultural e espetáculos na Câmara Municipal de Ovar e, entre 2016 e 2021, colaborou como museóloga para a Associação dos Antigos Alunos da Escola Oliveira Lopes, no Museu Escolar Oliveira Lopes em Válega, Ovar, onde para além da normal prática museológica, foi a impulsionadora da criação de um serviço educativo.

\section{Abstract}

This reflection intends to introduce, in a succinct way, a systemic approach to infocommunication in the context of museological institutions. Grounded on the premise that museological actions and exhibition mechanisms are not neutral activities, but relevant for the representation and communication of the relationships established between societies and eras that rely upon the exhibited objects, one reflects on their importance and adequacy. Based on Edgar Morin's paradigm of complexity, a first statement of possible factors - internal and external that influence the information and communication processes inside and outside museums is uttered, as well as the identification of some relationships and potential axes of action.

Keywords: Complexity; Infocommunication; Influencing factors; museums

\section{Biographical note}

Bárbara Andrez has a degree in Theatrical Studies from the Superior School of Music and Performing Artes (ESMAE) and holds a master in Contemporary Artistic Creation from University of Aveiro Department of Communication and Art (UA/DECA) and a master in Museology from University of Porto Faculty of Arts. She is currently a FCT/CITCEM research fellow in the doctoral programme in Information and Communication in Digital Platforms, a joint course of FLUP and UA/DeCA. She worked in cultural action and production in Ovar's city hall and, between 2016 and 2021, collaborated as a museologist for the Oliveira Lopes Old Students Association in the Oliveira Lopes School Museum in Válega, Ovar, where, besides the normal museological activity, she created an educational service. 


\section{Da infocomunicação à definição de museu}

De uma forma geral, os museus, como repositórios da memória coletiva, sempre se constituíram das interações permanentes com a sociedade onde se inserem. É inegável, portanto, esta capacidade de algumas instituições, quase metamorfósica, que lhes permite adequar a comunicação e a disseminação das suas coleções à realidade. Porém, há que antever que, face a qualquer alteração, será sempre necessária uma visão museológica holística e integrada, baseada em dinâmicas estratégicas e equipas interdisciplinares que deverão ser equacionadas regularmente e em confrontação direta com os contextos específicos.

Falar de museus e dos processos infocomunicacionais que lhes estão subjacentes parece uma redundância, uma vez que a palavra comunicação surge espelhada no próprio conceito de museu. Segundo o Internacional Council of Museums (ICOM) o museu é uma instituição permanente sem fins lucrativos, ao serviço da sociedade e do seu desenvolvimento, aberta ao público, que adquire, conserva, investiga, comunica e expõe o património material e imaterial da humanidade e do seu meio envolvente com fins de educação, estudo e deleite (ICOM Portugal, 2015).

Não obstante, o que define estes processos infocomunicacionais e como compreendêlos?

Antes de mais, convém entender que a palavra processo abarca uma série de significados. Reportando ao dicionário Collins e ao dicionário Cambridge, processo identifica um método ou sistema (Collins, 2021) ou uma série de ações humanas ou alterações naturais que permitem que algo aconteça (Cambridge University Press, 2021). Por outro lado, a palavra infocomunicação advém da junção de dois conceitos que se interligam: informação e comunicação.

De acordo com Silva (2010) “O conceito de informação convoca (...) o de comunicação e ambos se reportam a um fenómeno humano e social que tem a ver com a capacidade simbólica de cada pessoa e com a necessidade de interação" (p. 115). 
Convém demarcar que, apesar de os conceitos se interligarem, informação não é comunicação, existindo uma relação intersubjetiva, em sintonia com Passarelli et al. (2014). Para estes autores, informação diz respeito a uma ordem do conteúdo, enquanto a comunicação proporciona uma ordem de relação, com vista à fabricação de um sentido, mas a "comunicação não corresponde em si a um fenómeno meramente social e cultural, ela é inseparável da dimensão informacional" (Gouveia \& Silva, 2020, p.29)

Silva (2006) reporta-se ainda à informação como um "conjunto estruturado de representações mentais e emocionais codificadas (...) e modeladas com/pela interaç̧ão social, passíveis de serem registadas num qualquer suporte material" ( $p$. 150). Quanto ao conceito de comunicação, considera que representa o "processo de transmissão de informação entre agentes que partilham um conjunto de signos e de regras semióticas (...) tendo como objectivo a construção de sentido (...) e pressupõe necessariamente informação sob a forma de mensagens ou conteúdos transmitidos" (p. 143).

Na translação destes conceitos para as instituições museológicas é de fácil compreensão que, em cada contexto, existirá naturalmente uma ordem na informação/conteúdo que ao longo dos anos foi produzido e a forma como a informação é comunicada será sempre variável, mediante o âmbito de cada uma das instituições. Não obstante, é necessário entender que estes processos infocomunicacionais adensam-se com as flutuações e fenómenos que ocorrem dentro e fora das próprias instituições. 


\section{Da complexidade aos fatores de influência}

Quando se definem e iteram os processos infocomunicacionais dentro das instituições museológicas, é necessário um pensamento transdisciplinar e sistémico que permita uma abertura dos mecanismos, decompondo possíveis relações, adicionando ou subtraindo, conforme cada caso específico.

Segundo Morin (2005), pensar nestas dependências é percecionar relações complexas no desenho de um paradigma, que se intitula complexidade. Afinal, o que é a complexidade e como podemos adequá-la aos processos infocomunicacionais em museus? Morin (2005) define a complexidade como um conjunto de "interações e de interferências entre um número muito grande de unidades (...) incertezas, indeterminação, fenômenos aleatórios" (p. 35), mas esta complexidade "não se reduz à incerteza, é incerteza no seio de sistemas ricamente organizados" (p. 35).

Percecionar os museus como sistemas complexos é compreender que eles se organizam e atuam dentro de um determinado ambiente e contexto(s) específico(s) e de acordo com uma intencionalidade orgânica. Por isso, é importante antever que as especificidades subjacentes a cada instituição museológica influenciam os seus processos infocomunicacionais, as suas interações/ações, uma vez que fatores internos e externos que decorrem do(s) contexto(s) interferem na gestão da informação, da metainformação e da transmissão de conhecimento relativo a objetos/artefactos que primam pela sua materialidade e a criações como instalações, performance, videoarte ou mapping que salientam a dimensão conceptual (e remetem para o mentefacto do artista/criador), e, em última instância, na forma como estes são expostos e comunicados. Assim, quando se desenham as ações de comunicação em instituições museológicas, será sempre necessária uma visão ampla e informada destes fatores de influência e inerente olhar sistémico que faça emergir problemas/necessidades, nomeadamente no que diz respeito ao estudo e gestão das coleções, ao papel do produtor/artista/criador, à constituição das equipas, aos visitantes, à gestão dos recursos, aos equipamentos e coleções, ao orçamento, ao 
organograma, entre muitos outros fatores tais como: os stakeholders, as leis e definições orgânicas do país, a promoção do turismo, o ambiente, contexto e sociedade onde se inserem, bem como as interações latentes com a comunidade.

O esquema apresentado na Fig. 1 constitui uma primeira sistematização de possíveis fatores internos e externos que decorrem da influência do paradigma da complexidade em museus. De notar que visitantes e stakeholders apresentam-se no grupo de influência interna e externa. Isto prende-se com a capacidade participativa e de integração de cada instituição com as suas comunidades. Quando se trata de um ecomuseu por exemplo, visitantes e stakeholders expressam-se no interior das instituições, porque a premissa e apelo à participação se adequa à missão do museu. 0 mesmo acontece com outras instituições, onde os visitantes são integrados como participantes ativos nas ações. Porém não se deve deixar de considerar que, em muitos museus, esta relação de influência será apenas externa. 


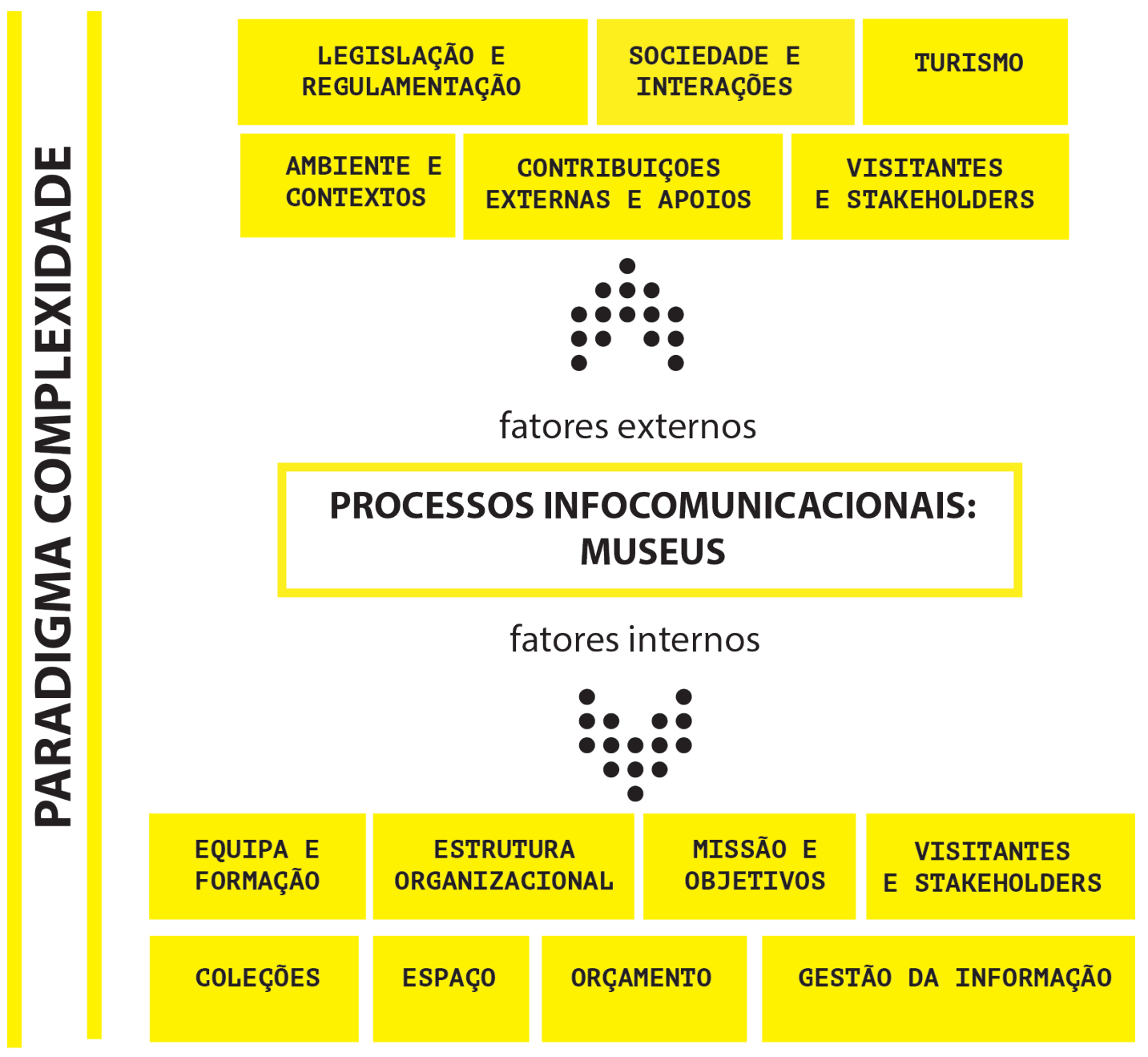

Fig. 1 - Esquema de possíveis relações dos processos infocomunicacionais em museus e o paradigma da complexidade. CBárbara Andrez, 2021.

A inclusão das Tecnologias da Informação e Comunicação (TIC) em ambientes museológicos, por exemplo, proporcionou uma produção e gestão da informação relativa às coleções que contribuiu para uma sistematização da informação relevante. Porém, por si só, essa informação não é geradora, nem sinónimo, de comunicação. A aquisição e uso de softwares que permitem esta gestão informacional, apenas conduzem a uma melhoria na procura, no sistema de filtros e na agregação de documentos e outros conteúdos relacionados com determinado objeto que, no caso de uma exposição, ação de serviço educativo, ou outra, necessitará de ser comunicada. 
Concordando que "Informer n'est pas communiquer" (Wolton, 2009), a informação e metainformação que estes sistemas contêm, ou outros semelhantes, irá sofrer sempre uma segregação à volta de um sentido ou propósito, muitas vezes não plenamente consciente, provida pelas mãos de um curador, de um museólogo, de um educador ou até de um conservador. Indo mais longe, como todas as instituições museológicas se constituem como sistemas orgânicos as suas coleções apresentam, também elas, os seus próprios contextos, identificando-se como sistemas dentro de sistemas. Acresce que, segundo Pearce (1994), os objetos existem numa relação espacial com outros objetos e paisagens e o estudo destas relações é benéfico para os entender e comunicar. Assim, a biografia dos objetos pode constituir-se como uma fonte informacional relevante e simbólica (Kopytoff, 1986), onde percecionar e entender os objetos para além da sua morfologia, função e utilização, poderá ser essencial para a produção de significados mais amplos, refletindo não só a história, mas também a cultura e agentes sociais.

Conforme a Fig. 2 sistematiza, entender as experiências e processos infocomunicacionais em museus é promover um processo científico que determine e valide a produção informacional, a representação dos conteúdos e sua organização (Silva, 2010), de acordo com as necessidades inerentes de cada instituição museológica e todas as suas influências. 


\section{PROCESSOS INFOCOMUNICACIONAIS}

\section{COLEÇÕES E OBJETOS EM MUSEUS}

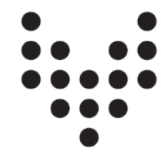

HISTÓRIA

E BIOGRAFIA

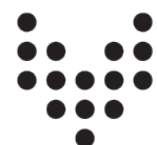

CONTEXTOS

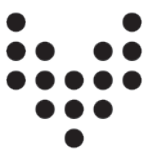

PROVENIÊNCIA

E PRODUÇÃO

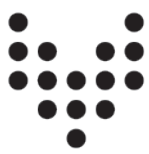

RELAÇÕES

Fig. 2 - Possíveis relações complexas a partir das coleções e objetos em museus. (C Bárbara Andrez, 2021

Não se trata somente de proceder à recolha nostálgica de objetos como testemunhos de proveniência, mas sim pensar nos mecanismos expositivos e ações museológicas como atividades que não são neutras, mas relevantes para a transmissão de relações entre sociedades a partir das coleções que constituem/gerem e expõem.

\section{Considerações finais}

É concludente afirmar que os processos de infocomunicação são intrínsecos à atividade humana, uma vez que decorrem da aglutinação dos conceitos de informação e de comunicação, essenciais para a partilha e retenção de conhecimento, sem os 
quais os indivíduos não conseguem interagir, nem produzir significância. Então, pensar nestes processos em museus é fomentar novas dimensões complexas, em sistemas orgânicos influenciados por fatores internos e externos nas próprias instituições. Estas reflexões paradigmáticas à volta de um pensamento complexo, permitem questionamentos válidos e melhorias, através do recurso a estratégias que possibilitam, depois de identificados, a mitigação de problemas sistémicos, melhorando também a consolidação da transmissão e retenção de conhecimentos informais, tão fundamentais à missão das instituições museológicas.

Assim, potenciar a informação e a comunicação sobre coleções e os artefactos e criações artísticas que as constituem em instituições museológicas é promover relações, desenvolver capacidades, preservar a história para o futuro e, sobretudo, garantir um acesso democratizado à formulação e retenção de conhecimentos informais, através do acesso ao património material e imaterial.

\section{Agradecimentos}

A autora expressa os seus agradecimentos, por todo o apoio prestado, às Prof. Doutoras Maria Manuela Pinto e Paula Menino Homem, FLUP, e à Fundação para a Ciência e a Tecnologia (FCT).

\section{Referências}

- Blair, A., Duguid, P., Goeing, A.-S., \& Grafton A. (Eds.) (2021). Information: A Historical Companion. New Jersey, Oxfordshire: Princeton University Press.

- Cambridge University Press (2021). Process. In Cambridge Dictionary. Disponível a 13 de junho, 2021, em: https://dictionary.cambridge.org/pt/dicionario/ingles/process 
- Collins (2021). Process. In Collins English Thesaurus. Disponível a 13 de junho, 2021, em: https://www.collinsdictionary.com/dictionary/englishthesaurus/process\#process__ 1

- Gouveia, L. B., \& Silva, A. M. d. (2020). A infocomunicação ou a convergência das Ciências da Informação e da Comunicação para um objeto comum. Páginas A\&B, S.3(№ Especial), 15-33. https://doi.org/10.21747/21836671/pag2020a2

- ICOM Portugal (2015, 19 de março). Definição: Museu. Disponível em: https://icom-portugal.org/2015/03/19/definicao-museu/

- Kopytoff, I. (1986). The cultural biography of things: commoditization as process. In A. Appadurai (Ed.), The Social Life of Things (pp. 64-91). Cambridge: Cambridge University Press.

- Morin, E. (2005). Introdução ao Pensamento Complexo. Porto Alegre: Editora Meridional.

- Passarelli, B., Ribeiro, F., Oliveira, L., \& Mealha, Ó. (2014). Identidade conceitual e cruzamentos disciplinares. In E. Senac (Ed.), E-Infocomunicação (pp. 79-121). São Paulo: Senac - Serviço Nacional de Aprendizagem Comercial.

- Pearce, S. (1994). Interpreting Objects and Collection. London, New York: Routlegde.

- Silva, A. M. d. (2006). A Informação: Da Compreensão do Fenómeno e Construção do Objecto Científico. Porto: Edições Afrontamento.

- Silva, A. M. d. (2010). A pesquisa e as suas aplicações em ciência da informação: implicações éticas. In G. H. d. A. Freire (Ed.), Simpósio Brasileiro de Ética da Informação Ética da Informação: Conceitos, Abordagens, Aplicações (pp. 106125). João Pessoa, PB: Ideia Editora Ltda.

- Wolton, D. (2009). Informer N'Est Pas Communiquer. Paris: CNRD Éditions. 


\section{Mariana Espel de Oliveira

Museu empreendedor: Usina de Eureka, um modelo de negócio para museus. 
Resumo

$\mathrm{Na}$ atualidade, os museus assumem uma nova dinâmica no que diz respeito à oferta de serviços e à sua relação com a sociedade. Este novo paradigma foi um estímulo para o desenvolvimento de estudo que apresenta um modelo de negócios para museus com a marca Usina de Eureka $^{\circledR}$. O desenvolvimento do modelo investigou, inicialmente, o ambiente museológico quanto à sua capacidade de gerar estímulos para o processo cognitivo criativo dos seus visitantes. Com resultados promissores advindos de estudos de caso realizados em dois museus da região centro de Portugal, foram, posteriormente, exploradas formas de auxiliar o público no desenvolvimento de ideias, que poderiam dar origem a novos produtos, serviços, soluções ambientais, entre outros. Para tal, foi criado o modelo de negócio que pretende ser uma interface facilitadora entre o público do museu e os agentes interessados no desenvolvimento de ideias inovadoras.

Palavras-chave: Museus; Empreendedorismo; Desenvolvimento Sustentável; Criatividade; Inovação

\section{Nota biográfica}

Mariana Espel de Oliveira é mestre em Museologia (FLUP), pós-graduada em Ciência Política com especialização em Políticas Públicas do Desenvolvimento Sustentável (U. Aveiro) e bacharel em Administração de Empresas (U. Norte do Paraná). Tem realizado projetos em museologia que contemplam o conceito de desenvolvimento sustentável. No mestrado, elaborou um modelo de negócio para museus. Como colaboradora voluntária do Centro para a Inovação, Tecnologia e Empreendedorismo (CITE INESC TEC), em articulação com o Centro de Investigação Transdisciplinar «Cultura, Espaço e Memória» (CITCEM), trabalha em projeto piloto para aplicação do modelo, objetivando reconhecer indicadores para mensurar níveis de sustentabilidade nos museus.

\section{Abstract}

Museums are currently taking on a new dynamic about the provision of services and their relationship with society. This new paradigm was a stimulus for the development of this study that presents a business model for museums with the Usina de Eureka ${ }^{\circledR}$ brand. The development of the model initially investigated the museological environment, in terms of its ability to generate stimuli for the creative cognitive process of its visitors. With promising results arising from case studies carried out in two museums in the Central Region of Portugal, ways were later explored to help the audience in the development of ideas that could give rise to new products, services, environmental solutions, between others. To this end, the business model was created, aiming to be a facilitating interface between the museum's audience and agents interested in the development of innovative ideas.

Keywords: Museums; Entrepreneurship; Sustainable Development; Creativity; Innovation

\section{Biographical note}

Mariana Espel de Oliveira has a master's degree in Museology (FLUP), a postgraduate degree in Political Science with a specialization in Public Policies for Sustainable Development (U. Aveiro) and a bachelor's degree in Business Administration (U. Norte do Paraná). She has carried out projects in museology that contemplate the concept of sustainable development. During the masters, she developed a business model for museums. As a volunteer researcher at Innovation, Technology and Entrepreneurship (CITE - INESC TEC), jointly with Transdisciplinary Research Centre «Culture, Space and Memory» (CITCEM), she works on a pilot project to apply this business model and conducts studies to recognize indicators to measure the level of sustainability in museums. 


\section{Introdução}

No ano de 2019, a autora desenvolveu um modelo de negócio para museus como projeto para conclusão do curso e consequente obtenção do grau de Mestre em Museologia, atribuído pela Faculdade de Letras da Universidade do Porto (FLUP) (Oliveira, 2019), cuja síntese partilha.

O projeto intitulado "Usina de Eureka. Museus como Impulsionadores da Inovação" apresentou um Modelo de Negócio (MN) para museus que tem em suas bases referenciais o conceito do Desenvolvimento Sustentável (DS) e o protagonismo dos museus em diversos setores, como, por exemplo, o setor educacional, de consciencialização ambiental, desenvolvimento social, económico e do microambiente em que está instalado.

Com o objetivo de dinamizar a atividade dos museus, o MN Usina de Eureka intenta contribuir para que estas instituições atribuam nas suas funções quotidianas uma ampla plataforma "viva", onde público e sociedade possam participar ativamente de sua rotina. Nestas perspetivas, o projeto Usina de Eureka propôs-se criar uma interface que atuasse em conjunto com o museu para apoiar o desenvolvimento e impulsionamento de novas ideias no mercado.

O projeto foi desenvolvido em duas fases. Primeiro foi necessário reconhecer se os ambientes dos museus apresentavam características que pudessem propiciar estímulos cognitivos criativos em seus visitantes e, com isso, promover no público um ambiente favorável à geração de ideias criativas. Com resultados promissores, foi então equacionado como poderiam os museus apoiar o público e colocar as suas ideias em prática. Para alcançar este objetivo foi elaborado um MN para museus que funciona como uma vitrina de ideias, onde os visitantes podem partilhar as inspirações que tenham durante a visita ao museu, através de uma interface de apoio com serviços de mediação entre setor público e privado para promover o suporte ao desenvolvimento de um novo produto, serviço ou mesmo um novo negócio. 
O MN incluiu nas suas diretrizes o conceito do DS, com o intuito de gerar um contributo para a sociedade que envolve o museu, tendo na sua génese uma característica entusiasta de impulsionamento do setor económico local.

\section{Enquadramento e objetivo}

O projeto alicerçou-se na experiência da autora, que depois das suas visitas a museus, constatou ter tido ideias para resolução de um problema e criação de um negócio.

Ao considerar a tendência nos museus para oferecer serviço de incubadora e apoio ao empreendedorismo, desenvolveu-se a ideia da Usina de Eureka, uma interface colaborativa que agrega, no museu, serviços para facilitar o desenvolvimento de novas ideias no público, sejam elas um novo produto alimentar, peças utilitárias de cozinha, um novo modelo de roupa ou negócio.

O passo seguinte foi validar a viabilidade do projeto. A literatura dos últimos dez anos, e até mesmo experiências práticas, demonstraram o protagonismo dos museus em novas formas de atuação na sociedade e apresentam estudos para mensurar qual a efetiva representatividade destas instituições. Tais evidências contribuíram para a continuidade do trabalho, que integra a expectativa de criar um elo colaborativo entre sociedade, museu e o seu público.

A publicação Museum Innovation and Social Entrepreneurship. A New Model for a Challenging Era (Eid, 2019) chama a atenção para uma contínua busca dos museus por novos modos de dinamização entre instituição, público e sociedade e salienta as diversas possibilidades e desafios que os museus enfrentam para desenvolver ações que poderão gerar resultados neste novo trinómio. Entre formas e modelos de dinamização e inovação, o autor cita exemplos como o desenvolvimento e (...) "aperfeiçoamento de processos, produtos ou modelos de negócio pelos quais os museus podem efetivamente alcançar suas missões sociais" (p. 7. Tradução da autora). 
Ao reconhecer a pertinência do estudo, foram definidos três objetivos de investigação: (1) Identificar se os visitantes dos museus reconhecem que têm uma ideia durante a visita e se são motivados a partilhá-la; (2) Desenvolver um MN inovador para captação e desenvolvimento das ideias geradas no museu; (3) Estruturar o MN de forma assertiva, permitindo ao museu colaborar com o DS da localidade e colocar o território no mapa da inovação.

\section{Metodologia}

A elaboração do $\mathrm{MN}$ foi dividida em duas fases. A primeira intentou reconhecer se os visitantes reportavam que tiveram uma ideia e se sentiam motivados a partilhá-la. Outra condição investigada foi de reconhecer se o ambiente dos museus estudados apresentava características que pudessem estimular o processo cognitivo criativo.

O mapa referencial teórico considerou temáticas de Museologia Social, Nova Museologia, Museologia, empreendedorismo e inovação, teorias sobre ambiente criativo, estruturação de modelos de negócio e bases teóricas sobre metodologia da investigação científica nas Ciências Sociais.

A abordagem para estudar se tais fenómenos eram reconhecidos pelo público dos museus foi realizada pela metodologia de Estudo de Caso em duas instituições da região centro de Portugal.

Com a aplicação de questionários, foi possível realizar um mapeamento do comportamento dos visitantes dos museus. Para a sua aplicação, foram utilizadas técnicas de definição de amostra por conveniência, recolha de dados quantitativos e qualitativos apresentados em formulário impresso aos visitantes de forma aleatória e o seu conteúdo teve como base referencial teórica os temas Museus, Criatividade e Ambiente Criativo. No tratamento dos dados utilizou-se a técnica de Estatística Descritiva para sintetização e organização da frequência do fenómeno estudado e 
também execução de correlação de frequências positivas entre as variáveis definidas, relativas ao facto do visitante ter partilhado uma ideia e a sua perceção quanto às características que estimulam a criatividade no ambiente dos museus.

Com os promissores resultados obtidos, impunha-se definir as bases metodológicas para elaboração do MN fundamentado pela coordenação do poder público local, empresários, comunidade, centros de investigação, especialistas em análise de negócios, investidores e os visitantes dos museus, para auxiliar estes últimos na prospeção das suas ideias e, consequentemente, contribuir para o desenvolvimento económico do território.

Para delinear o MN foi necessário definir um ambiente de possível implementação, pois a sua estrutura organizacional necessita de uma base referencial para definição de parâmetros de ação. Por este motivo e conveniência da investigadora responsável, foi definido o macro ambiente de Portugal como base do projeto. Para o efeito foram utilizadas as seguintes opções teórico-metodológicas:

- Referencial teórico. Falk e Sheppard (2006, citado em Donley, 2014, p. 19) define a importância de um MN para museus ter em consideração as necessidades tanto do público quanto da instituição e também de fazer uso das experiências dos visitantes, contemplando na sua estruturação os ativos internos, externos, necessidades e ativos financeiros, e conciliando o contexto social, político e económico;

- Tomada de decisão. O processo foi fundamentado pelas diretrizes apresentadas na Tab. 1, definidas com base no documento do Plano Nacional de Coesão Territorial de Portugal (República Portuguesa, 2017);

- Consulta de relatórios governamentais de Planeamento Estratégico Nacional, Planos Diretores Municipais, para identificar as lacunas delimitadas nos Relatórios Nacionais, nomeadamente no que diz respeito às diretrizes do DS. 
Na Tab. 1, no sentido vertical, encontram-se os indicadores definidos com base no Planeamento Estratégico de Coesão Territorial de Portugal (República Portuguesa, 2017). A definição destes indicadores considerou quais os possíveis contributos para o DS em que esta interface colaborativa poderia envolver-se e gerar resultados, com base nos parâmetros definidos por Falk e Sheppard (2016, citado em Donley, 2014, p. 19), na coluna horizontal.

A metodologia utilizada para a tomada de decisão foi baseada no Modelo Comportamental, considerando que a proposta de tomada de decisão foi realizada por meio de critérios e observações feitas de forma singular.

Tab. 1 - Indicadores para escolha do museu de referência para estrutura da Usina De Eureka (Oliveira, 2019, p. 40).

\begin{tabular}{|l|l|l|l|}
\hline $\begin{array}{l}\text { Contexto Social e } \\
\text { Político }\end{array}$ & $\begin{array}{l}\text { Contexto } \\
\text { Económico }\end{array}$ & Ativos Internos & Ativos Externos \\
\hline $\begin{array}{l}\text { Museus situados em } \\
\text { de Portugal com baixa } \\
\text { densidade }\end{array}$ & $\begin{array}{l}\text { Reduzida oferta de } \\
\text { trabalho no } \\
\text { território. }\end{array}$ & Museus. & $\begin{array}{l}\text { Representantes do } \\
\text { setor privado. }\end{array}$ \\
\hline $\begin{array}{l}\text { Museus situados em } \\
\text { zonas limítrofes a } \\
\text { municípios de média } \\
\text { dimensão. }\end{array}$ & $\begin{array}{l}\text { Reduzidas ou } \\
\text { inexistentes } \\
\text { organizações de } \\
\text { apoio ao } \\
\text { empreendedorismo. }\end{array}$ & No de visitantes & Investidores. \\
\hline $\begin{array}{l}\text { Municípios com mais } \\
\text { de 10.000 habitantes. }\end{array}$ & $\begin{array}{l}\text { nover. } \\
\text { jovens em idade } \\
\text { laboral. }\end{array}$ & $\begin{array}{l}\text { Especialistas em } \\
\text { inovação e negócios. }\end{array}$ \\
\hline
\end{tabular}




\begin{tabular}{|l|l|l|l|}
\hline & & $\begin{array}{l}\text { planeamento } \\
\text { estratégico. }\end{array}$ \\
\hline & & $\begin{array}{l}\text { Atuação de centros de } \\
\text { investigação como } \\
\text { colaboradores e } \\
\text { participantes ativos } \\
\text { no projeto. }\end{array}$ \\
\hline
\end{tabular}

\section{Referencial teórico}

Neste ponto, serão apresentadas as referências de caráter científico e empírico, e exemplos de museus que implementaram projetos que, de alguma forma, se assemelham ao conceito da Usina de Eureka.

A revisão bibliográfica relaciona os temas Museus e o Desenvolvimento Sustentável, Museus, Incubadoras e Empreendedorismo, Open Innovation, Museus - Criatividade e Inovação.

\subsection{Reconhecimento dos museus como dinamizadores do DS}

Neste contexto, o referencial teórico foi baseado em referências científicas publicadas entre os anos de 2009 e 2019 sobre Ciência Política, Ciências Sociais, Ciências Ambientais, Administração Pública e Museologia.

O conceito de DS tem o seu início marcado pela elaboração do conhecido por Relatório Brundtland em 1987, traduzido para língua portuguesa em 1991, intitulado Nosso Futuro Comum (Comissão Mundial sobre Meio Ambiente e Desenvolvimento, 1991). O Relatório Brundtland esteve no centro das discussões da Organização das Nações Unidas (ONU), no período após segunda guerra mundial. Em 2002, 2012 e 2015 novas 
cimeiras aconteceram para discutir resultados, práticas e ensinamentos da aplicação desta agenda desenhada na cimeira Eco`92.

O Relatório definiu um roteiro que indica diretrizes para o desenvolvimento ordenado da sociedade, que pode ser comparado a um conjunto de engrenagens que colocam em funcionamento uma máquina. O funcionamento destas três engrenagens (Pilar económico, social e ambiental) em sintonia, proporcionam um desenvolvimento económico que respeita e colabora com a sociedade, reconhece a escassez de bens materiais e preza pela preservação ambiental, para garantir a qualidade de vida para as futuras gerações (Comissão Mundial sobre Meio Ambiente e Desenvolvimento, 1991).

Hopwood, Mellor e O'Brien (2005) defendem que as diretrizes para o DS das nações, definidas em 1987, continuam a gerar resultados positivos e salientam a relevante contribuição do Relatório: a de definir parâmetros para mensurar e direcionar investimentos e ações pelo setor público e privado, na busca de soluções que integrem um conjunto de sinergias entre indivíduo, instituições, sociedade, setor público e privado, objetivando um ciclo equitativo de desenvolvimento.

Apesar destas diretrizes terem sido colocadas em prática na década de 80 do século $X X$, com alterações e melhorias, a relação dos museus com o conceito foi enfatizada na última cimeira. Antes, os museus eram vistos propriamente como agentes educativos e de consciencialização. Foi no lançamento da Agenda 2030 da ONU, ocorrida em 2015 em Nova lorque, que o sector cultural foi considerado como um relevante motor de desenvolvimento da sociedade. Neste momento, os museus passam a ser motivados para desenvolver ações além das educativas e de consciencialização (UNESCO Culture Sector, 2018). Os autores Gustafsson e ljla (2016) salientam que os museus atuam como instrumentos para alcançar os fenómenos almejados na Agenda 2030 da ONU através da coesão entre os diferentes setores da sociedade, reflexões sobre a tolerância, democracia e crescimento económico, através do incentivo ao senso 
coletivo de lugar, memória coletiva, integração social, educação ambiental e manutenção das cidades.

Com o reconhecimento deste novo paradigma para os museus, é apresentada, em seguida, uma cronologia da relação do reconhecimento dos museus como um dinamizador do empreendedorismo, atividade esta que poderá ser cada vez mais um contributo assertivo para a sua ação colaborativa para o DS da sociedade.

\subsection{Apoio ao empreendedorismo nos museus e Open Innovation}

Com o novo protagonismo dos museus, a prestação de serviços diferenciados atendendo às necessidades do território passou a ser uma realidade. Um dos modelos de prestação de serviço já existente nos museus é o apoio ao empreendedorismo, serviço este que, reconhecidamente, gera impacto no Produto Interno Bruto (PIB), através da implantação de projetos de aspeto económico aliados ao património cultural local (Bălan \& Vasile, 2015). Como exemplo, o New INC sediado na cidade de Nova lorque. Foi o primeiro museu a incorporar na sua estrutura uma incubadora que, atualmente, conta com oito mil metros quadrados dedicados ao apoio, assessoria e desenvolvimento de novos negócios (New INC, 2019).

Um segundo caso pode ser consultado em um mapeamento realizado no ano de 2018 pela Network of European Museum Organisation (NEMO), que mostra os impactos positivos advindos dos programas de implementação de serviços de incubadora de empreendedorismo nos museus como apoio à indústria criativa, promoção do primeiro emprego de jovens estudantes e recuperação de museus em risco de abandono (Bailey, 2018, p. 4).

Também uma importante referência do ramo de startups, Turoczy (2017), salienta a eficiência da parceria dos museus na prospeção de novos negócios. 
Para atender a este novo paradigma, são sugeridos os modelos de open innovation e empreendedorismo social como facilitadores na inclusão de serviços que atribuem um contexto de inovação aos museus (Eid, 2015).

O conceito de Open Innovation permite que processos criativos de diversas temáticas sejam partilhados entre diferentes agentes, o que não ocorre dentro de um centro de investigação fechado pois, nessas condições, muitos fenómenos criativos podem ser perdidos pela falta de utilidade naquele ambiente (Chesbourgh, 2003). No Projeto Usina de Eureka, o conceito Open Innovation aparece como alternativa, considerando que o MN objetiva acolher ideias de diversas temáticas e compor o maior número de agentes interessados possíveis, assumindo que o público será livre para expor suas ideias para análise de viabilidade, independente do tema assumido.

Em suma, o empreendedorismo nos museus é um tema que desperta o interesse entre os profissionais da área e até mesmo dos que estão fora do dia a dia dos museus e reconhecem a sua potencialidade.

\subsection{Museus - Criatividade e inovação}

O reconhecimento do museu como um ambiente criativo pode até ser considerado consensual, tendo em vista que estas instituições exigem uma dinâmica constante de estudos para desenvolver diferentes formas e maneiras de empreender, da melhor forma possível, uma conexão entre público e o "conteúdo" do museu.

Como o Projeto Usina de Eureka tem como matéria-prima a inspiração criativa do público dos museus, foi imprescindível aprofundar o conhecimento relativamente a criatividade e inovação.

Por diversas vezes, os termos criatividade e inovação são interpretados como sinónimos. No entanto, a literatura demonstra a diferença entre estes dois conceitos (Agars, Kaufman \& Locke, 2008). 
A definição mais recente do que é um processo criativo no ser humano está relacionada com o pensar de uma nova ideia, e que este pensar de uma nova ideia deve interagir com as suas aptidões, tendo como impulsionador um processo ou ambiente que estimula a criação de um produto novo, reconhecido e útil. Tais pressupostos para o reconhecimento de um produto devem ser entendidos dentro de um contexto social (Plucker, Beghetto, \& Dow, 2004 citado em Bisadi \& Hosseini, 2012, p. 233).

Já Tanner (2004 citado em Bisadi \& Hosseini, 2012, p. 234) define que a inovação está relacionada com o resultado da aplicação prática de uma ideia criativa, ideia esta que é, essencialmente, gerada a partir do momento em que o indivíduo tem a perceção de um problema e de que precisa resolvê-lo.

Ao reconhecer os conceitos de criatividade e inovação, o passo seguinte foi identificar, na literatura, características de um ambiente criativo, presentes nos museus.

Poucos conteúdos foram encontrados sobre o museu como ambiente criativo. Pode considerar-se uma referência significativa o trabalho desenvolvido por Inês Ferreira, intitulado “Criatividade nos Museus. Espaços entre e Elementos e Mediação" (Borges, 2015). A autora salienta a falta de trabalhos que mensurem e indiquem caminhos para que os museus possam tornar mais criativos o seu discurso expositivo, os seus espaços e os serviços que prestam.

Outra referência relevante para o tema, Fisher (2018), sugere que os museus devem elaborar modelos de atividades que possam agir de forma mais assertiva para influenciar a captação dos processos criativos gerados neste ambiente.

Um outro exemplo de trabalho que explora o ambiente criativo dos museus é o que foi desenvolvido no âmbito do programa "A Mochila Cultural". A autora (Frimpong, 2017) desenvolveu um projeto simultâneo com um segundo investigador no Gana, onde crianças e adolescentes eram induzidos a criar produtos para reutilização de alumínios a partir de materiais recicláveis. Na Noruega, todo o processo criativo foi realizado no 
Aluminum Museum Holmestrand, em Oslo. Em contrapartida, no Gana, o processo criativo foi realizado em ambientes diversos. Dadas as dificuldades sociais existentes, não havia um local fixo e as oficinas foram realizadas até a céu aberto. Segundo Frimpong (2017), o facto de o museu oferecer ao indivíduo a possibilidade de autonomia na aprendizagem, ser um ambiente propício para a individualidade e, também, comunicar o processo de inovação através do seu discurso expositivo, facilita a indução de processos cognitivos que geram a criatividade. Na Noruega, os produtos criados no programa foram utilizados como peças de revenda na loja do museu, revertendo em rendimentos para a instituição.

Quanto ao contexto relacionado com museus e inovação, o estudo de Eid (2015), denominado "The Museum Innovation Model: A Museum Perspective on Open Innovation, Social Enterprise and Social Innovation" utiliza como fator principal de discussão a problemática da inovação nos museus e apresenta, como uma solução para o desenvolvimento social, o desenvolvimento de modelos de negócio baseado na gestão empresarial personalizada para museus.

Para exemplificar, de forma sucinta, o que se espera de um processo inovador no museu, Nilsson (2014) esclarece que

\section{(...) Museum innovation constitutes novelty/change that is a break with business as usual in a broader context, either to the sector (regionally, nationally or globally) or a specific market (i.e., museum audiences) (p. 68).}

Com este conjunto de referenciais desenvolveu-se o Projeto Usina de Eureka (Oliveira, 2019), cujos resultados e consequente estruturação de um MN se apresentam sucintamente de seguida.

\section{Resultados}

Os resultados apresentam-se separadamente respeitando as fases às quais pertencem. 


\subsection{1a fase}

Conforme referido, a primeira fase da investigação considerou o estudo de caso de dois museus da região centro de Portugal. Recorreu-se à aplicação de um questionário intitulado "Usina de Eureka: Produzindo novas ideias nos museus", que continha dezassete perguntas. A meta consistia em identificar se o público do museu reconhecia o fenómeno de ter tido uma ideia para solucionar um problema e também, com base nas suas respostas, se apresentavam uma perceção de características do ambiente do museu que estimulavam o fluir de ideias criativas.

Os museus selecionados foram os seguintes:

- Museu Monográfico de Conimbriga (MMC) (Fig. 1), situado no município de Condeixa-a-Nova, Portugal. Tem a sua temática associada aos objetos resgatados da área de escavações arqueológicas da antiga povoação de Conimbriga, ocupada pelos Romanos em 139 a.C. O MMC é de tutela nacional gerido pela Direção-Geral do Património Cultural;

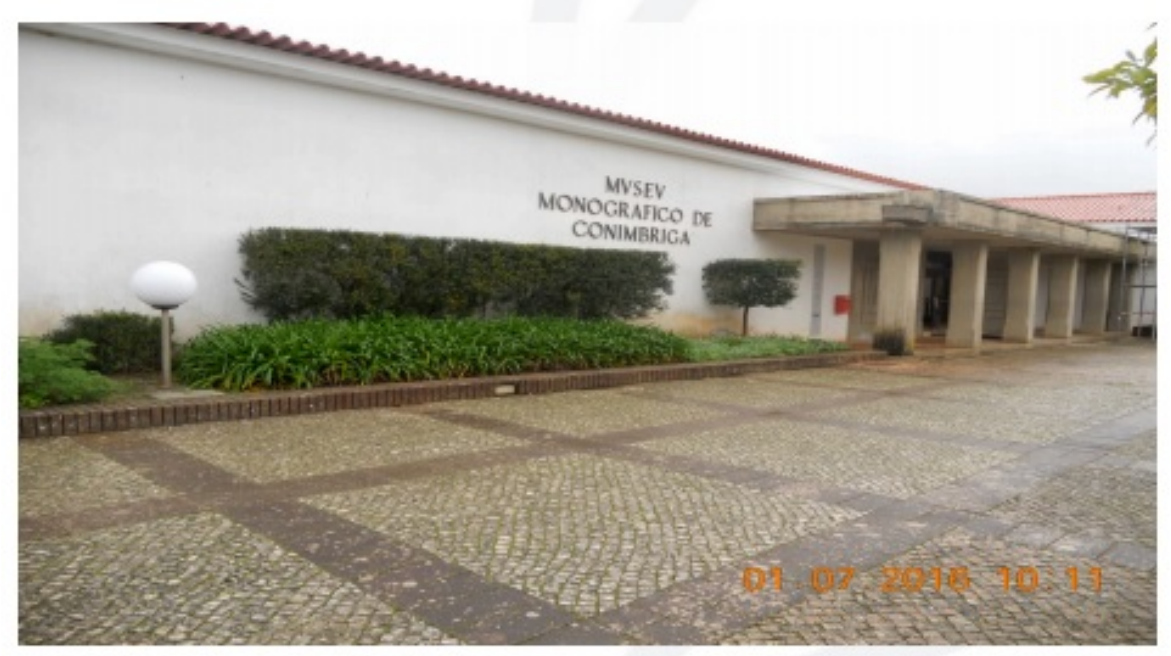

Fig. 1 - Fachada da entrada principal do Museu Monográfico de Conimbriga e Ruína (Oliveira, 2019, p. 58). 
- Museu da Água de Coimbra (MAC) (Fig. 2), situado no município de Coimbra, Portugal. O discurso expositivo considera a história da empresa responsável pela distribuição de água e saneamento no município. O museu oferece exposições temporárias de obras de arte de artistas locais e de objetos utilizados pela empresa e serviços educativos para diferentes faixas etárias. Ocupa o espaço da antiga estação de captação de água da cidade, datada de 1922.

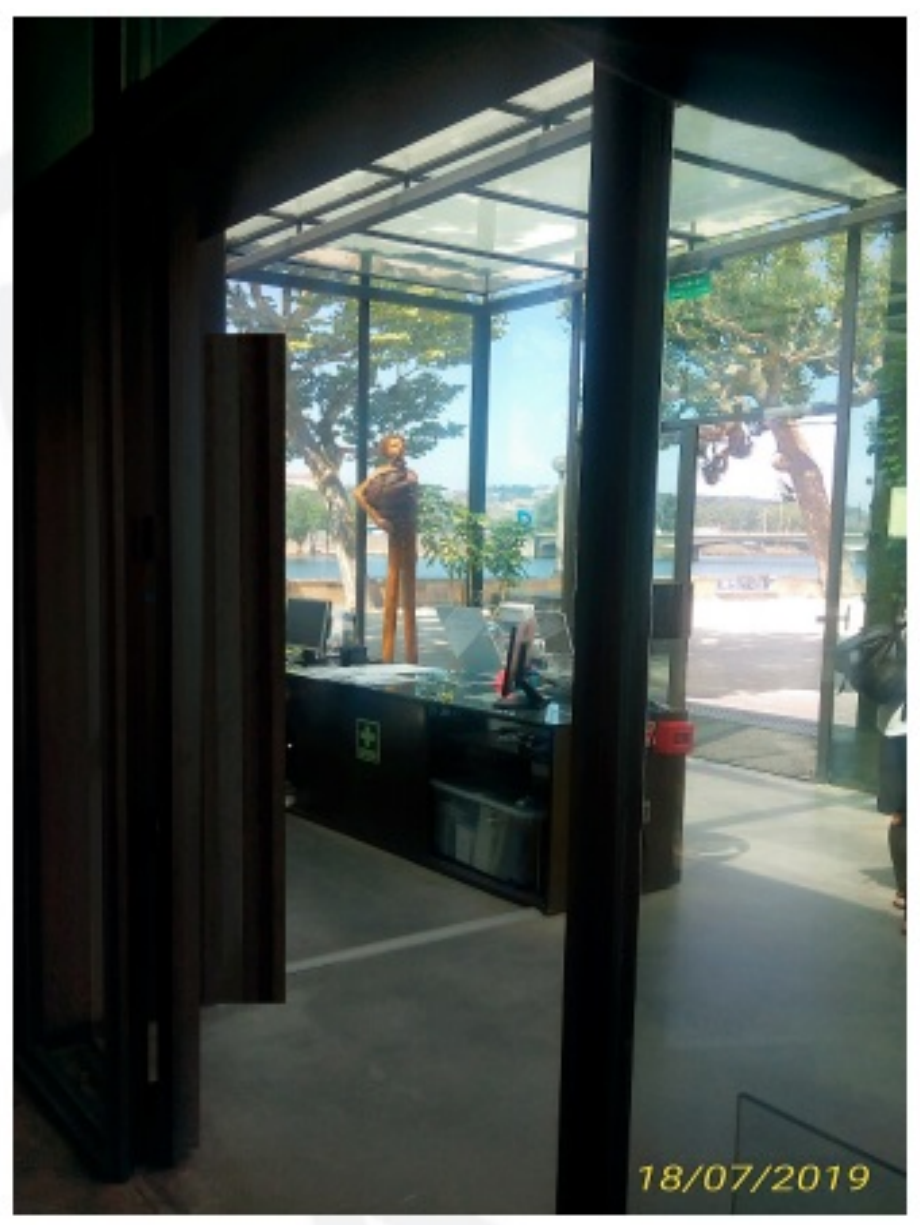

Fig. 2 - Museu da Água de Coimbra. Local onde foi aplicado o questionário (Oliveira, 2019, p. 60).

Os resultados apresentados demonstram, em termos percentuais, a frequência de respostas positivas ou negativas relativamente aos inquiridos que partilharam uma ideia. 
Através da Estatística Descritiva e com apoio do software Statistical Package for the Social Science (SPSS) foi realizado o tratamento de dados obtidos, resultando em:

- No caso do MMC (Fig. 3), das dezoito pessoas inquiridas, 55,6\% partilharam uma ideia, enquanto $44,4 \%$ não o fizeram.

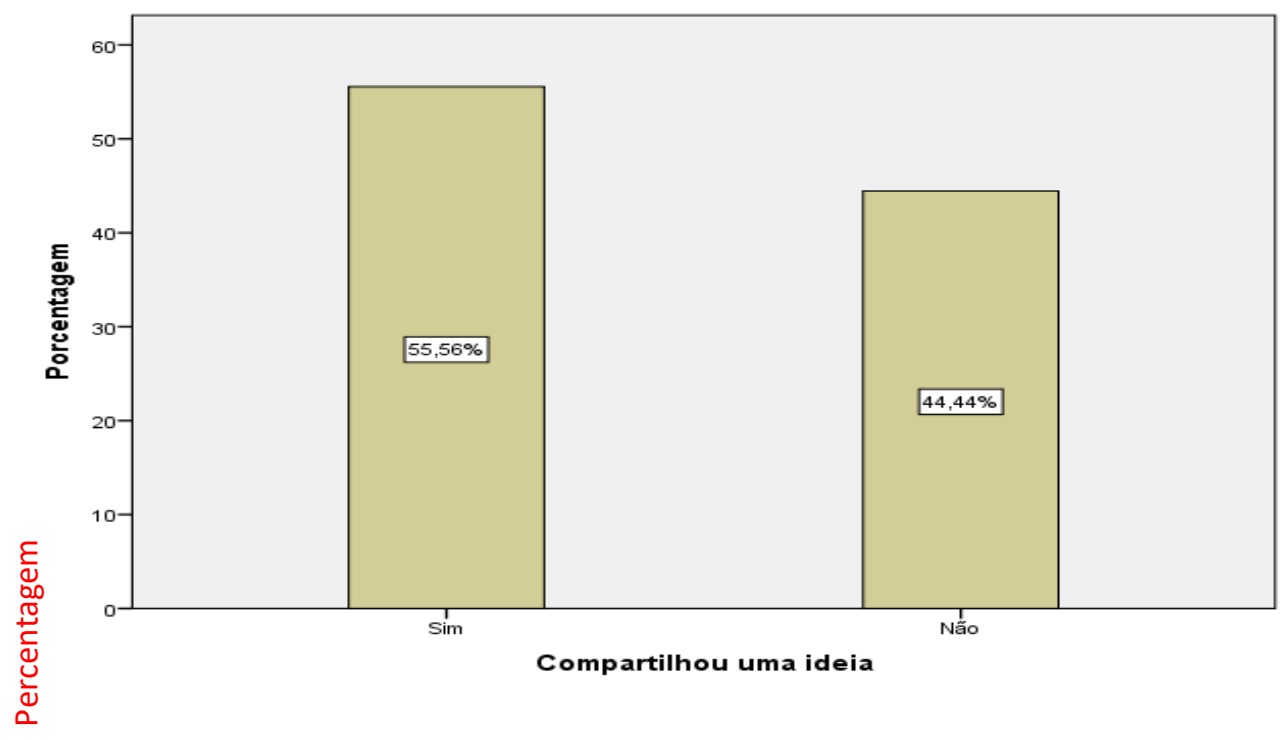

Partilhou uma ideia

Fig. 3 - Gráfico relativo aos resultados do inquérito desenvolvido no Museu Monográfico de Conimbriga (Oliveira, 2019, p. 62).

Para determinar o intervalo de confiança desta amostra foi necessário pesquisar informação sobre a média diária de visitantes do museu. A base referencial utilizada foi o Estudo de Públicos dos Museus Nacionais publicado em junho de 2019 referente ao MMC que teve como referência o número de visitas anuais de 2010 até 2016 (Direção-Geral do Património Cultural, 2019).

Com base nestes dados, foi realizado um cálculo da média diária de visitas e o resultado foi que, nos anos estudados, a instituição recebeu uma média de trinta e seis visitantes por dia. A partir destas amostras e com apoio do software Sample Size Calculator, foi possível reconhecer o intervalo de confiança de 95\%, com a margem de erro de $16,5 \%$. 
Com base nos resultados obtidos e apresentados na Tab. 2, é expectável que o número de partilhas diárias de ideias do público possa variar de 7 a 12 unidades de ideias, valores que poderão somar em um mês de funcionamento até 360 partilhas de diferentes ideias criativas.

Tab. 2 - Partilha de ideias, com intervalo de confiança, relativamente ao MMC (Oliveira, 2019, p. 64).

\begin{tabular}{|l|l|l|}
\hline $\begin{array}{l}\text { *Percentagem de ideias } \\
\text { partilhadas por dia de } \\
\text { funcionamento }\end{array}$ & $\begin{array}{l}\text { № de ideias partilhadas, } \\
\text { por dia de funcionamento }\end{array}$ & $\begin{array}{l}\text { № de ideias que poderiam } \\
\text { ser partilhadas por mês }\end{array}$ \\
\hline$* * 55,6 \%$ & 10 & 300 \\
\hline $71,5 \%$ & 12 & 360 \\
\hline $39,1 \%$ & 7 & 210 \\
\hline$*$ A percentagem apresentada é referente ao universo de 36 visitantes/dia. \\
\multirow{2}{*}{$* *$ Dos 18 inquiridos, 55,6\% partilharam uma ideia, o que equivale a 10 partilhas. } \\
\hline
\end{tabular}

- No caso do MAC (Fig. 4), dos catorze inquiridos, 7,14\% partilharam uma ideia. 


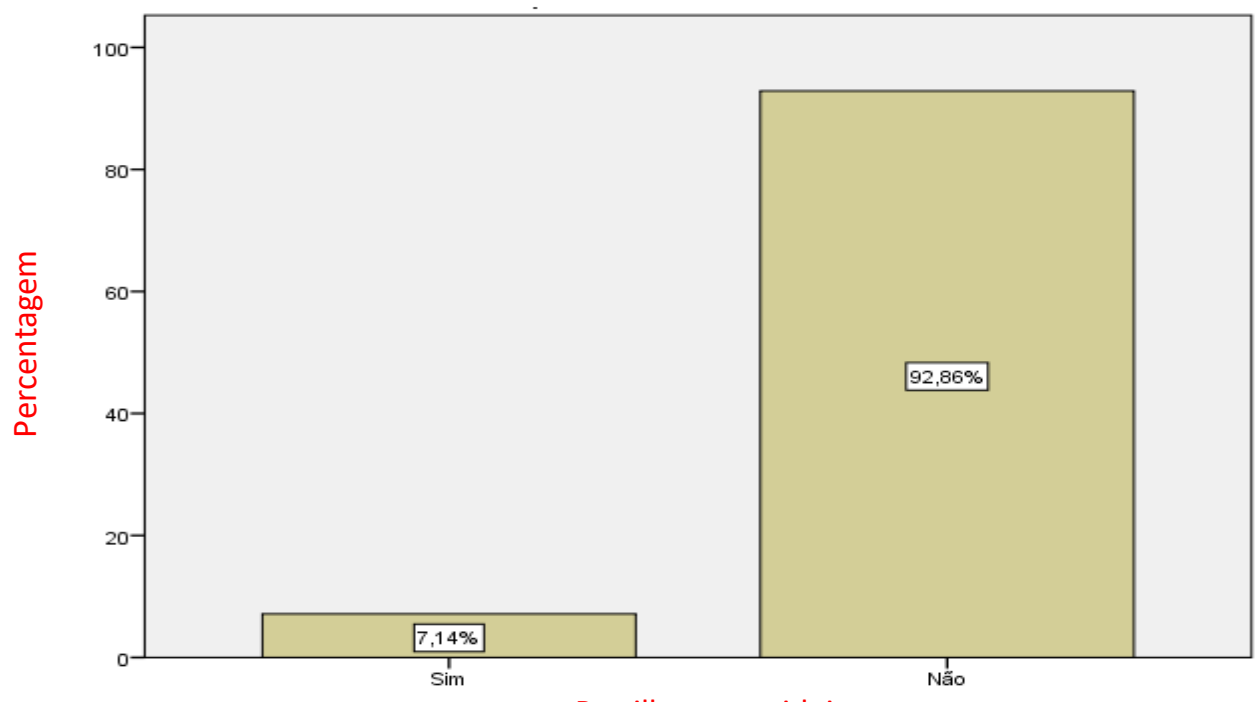

Partilhou uma ideia

Fig. 4 - Gráfico relativo aos resultados do inquérito desenvolvido no Museu da Água de Coimbra (Oliveira, 2019, p. 66).

A informação para determinar a margem de erro relativa à média de visitantes diários foi retirada de uma publicação no Jornal Notícias de Coimbra, versão digital, que considerou os anos de 2008 até 2016 (Jornal Notícias de Coimbra, 2019). A média de visitantes obtida foi de quarenta pessoas por dia.

Com o apoio do software Sample Size Calculator online, foi obtido um intervalo de confiança de $95 \%$ e margem de erro de $14,8 \%$. Os resultados expressos na Tab. 3 demonstram que, com a margem de erro acima mencionada, poderá ocorrer a condição de não se obter nenhuma partilha de ideias em um dia de funcionamento do museu ou então, apenas uma partilha de ideia poderá acontecer. No cenário mais otimista, o museu poderá obter até 31 unidades de ideias durante um mês de funcionamento. Já no cenário pessimista, haverá a possibilidade de não haver nenhuma partilha de ideia.

Tab. 3 - Partilha de ideias, com intervalo de confiança, relativamente ao MAC (Oliveira, 2019, p. 65). 


\begin{tabular}{|c|c|c|}
\hline $\begin{array}{l}\text { *Percentagem de ideias } \\
\text { partilhadas por dia de } \\
\text { funcionamento }\end{array}$ & $\begin{array}{l}\text { № de ideias partilhadas, } \\
\text { por dia de funcionamento }\end{array}$ & $\begin{array}{l}\text { № de ideias que poderiam } \\
\text { ser partilhadas por mês** }\end{array}$ \\
\hline$* * * 7,14 \%$ & 1 & 26 \\
\hline $21,9 \%$ & 1,2 & 31 \\
\hline 0 & 0 & 0 \\
\hline \multicolumn{3}{|c|}{ *O MAC não abre na 2a feira. Por este motivo foram considerados 26 dias. } \\
\hline \multicolumn{3}{|c|}{ **A percentagem apresentada é referente ao universo de 36 visitantes/dia. } \\
\hline ***Dos 14 inquiridos, ho & apenas 1 partilha de ideias. & \\
\hline
\end{tabular}

Os dados obtidos, correspondentes ao facto de os visitantes dos dois museus terem tido a perceção de elementos e características que estimulam o pensamento cognitivo criativo, foram tratados com apoio do software SPSS e os gráficos foram elaborados apoio do software Excel.

Das dezassete questões formuladas, treze foram dedicadas ao tema ambiente criativo.

Nesta análise, a intenção foi reconhecer se havia uma correlação entre respostas positivas no quesito de reconhecimento de elementos e características de um ambiente criativo e a partilha de ideias. Os resultados foram tratados a partir da técnica de soma de pontos. Foram, então, delimitados dois itens de análise. Quando a resposta era positiva o item Resposta Positiva recebia um ponto e quando a resposta era negativa, o item correspondente recebia um ponto. Com este somatório, foi feita a correlação entre o número de pontos para Respostas Negativas e Positivas e o número de partilha de ideias. Os resultados obtidos foram: 
- No caso do MMC, o gráfico na Fig. 5 mostra que os somatórios das repostas obtidas totalizam 234 pontos. No entanto, foram obtidas respostas consideradas nulas, que são aquelas em que os inquiridos deixaram de responder ou escolheram, na escala Lickert, a opção de nível 3, não concordo nem discordo. Estas respostas foram consideradas nulas e sem opinião e são apresentadas desta forma. Dos questionários analisados, 8 respostas foram consideradas nulas e 1 sem opinião, e como consequência, a análise apresentada totalizou 225 pontos.

As respostas positivas quanto à perceção de característica de um ambiente criativo no museu somaram 200 pontos e as respostas negativas, somaram 25 pontos. Os resultados demonstram também que das 200 respostas positivas, 110 pontos foram provenientes do grupo de pessoas que partilharam uma ideia. Já o grupo que não partilhou uma ideia, respondeu positivamente em 90 questões.

As respostas negativas somaram 25 pontos, com divisão equilibrada entre os grupos que partilharam uma ideia e os que não partilharam.

O valor total representado corresponde ao somatório de pontos esperado da totalização de todas as respostas do questionário aplicado. Por este motivo o valor diverge da análise do gráfico. Este valor só poderá ser obtido considerando também as respostas que foram anuladas. 


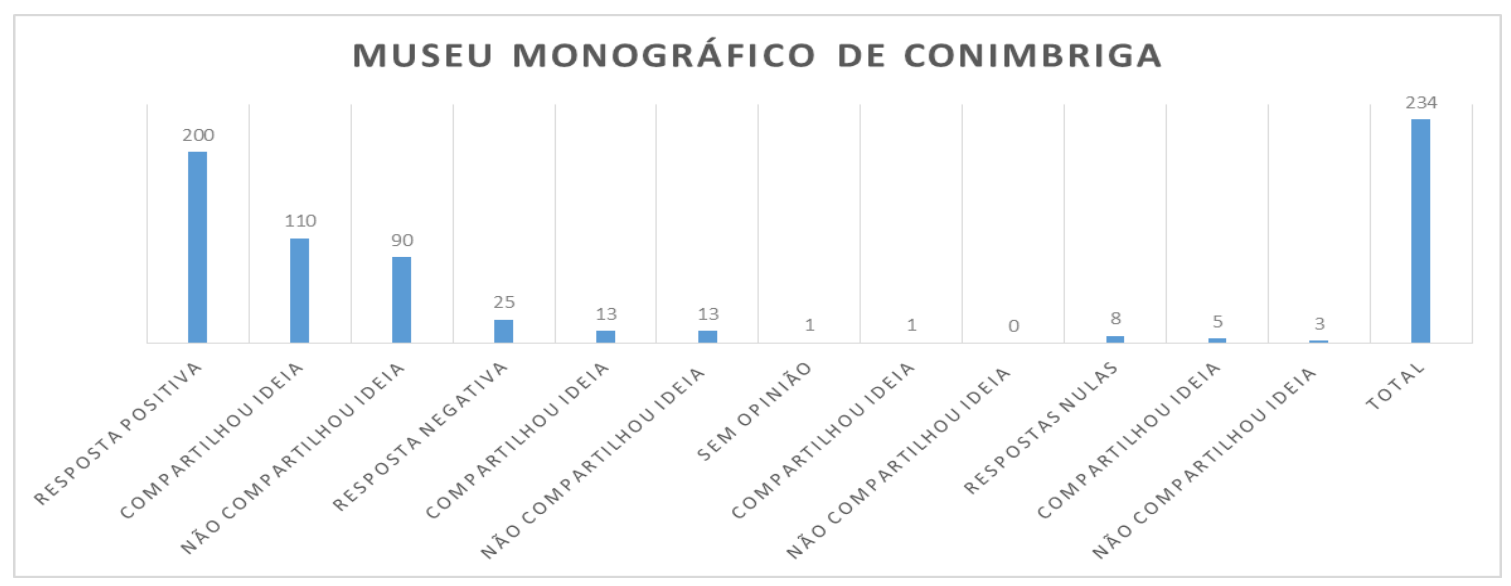

Fig. 5 - Gráfico referente à relação de respostas positivas e negativas, no Museu Monográfico de Conimbriga (Oliveira, 2019, p. 67).

- No caso do MAC, o gráfico na Fig. 6 mostra que o somatório das repostas obtidas foi de 180 pontos. Dos 14 questionários aplicados, oito questões, deixaram de ser respondidas e em três casos, as opções de resposta estavam no nível 3 da escala Lickert, correspondente à opção Não Concordo Nem Discordo. Com a anulação das respostas acima descritas, o conjunto de respostas consideradas nesta análise totalizou 171 pontos. As respostas não consideradas estão representadas como Respostas nulas e Sem opinião.

O total de pontos referente às Respostas Positivas, que descrevem o reconhecimento do museu como um ambiente criativo, somaram 139 pontos. As Resposta Negativas, totalizaram 32 pontos.

Quanto à correlação entre a partilha de ideia e as respostas positivas e negativas, é possível verificar que, das 139 respostas positivas, 9 tiveram origem no grupo de inquiridos que partilharam uma ideia. As respostas 
negativas somaram 32 pontos e fazem parte dos inquéritos sem partilha de ideias.

O valor total representado corresponde ao somatório de pontos esperado da totalização de todas as respostas do questionário aplicado. Por este motivo o valor total apresentado só poderá ser obtido considerando também as respostas que foram consideradas nulas.

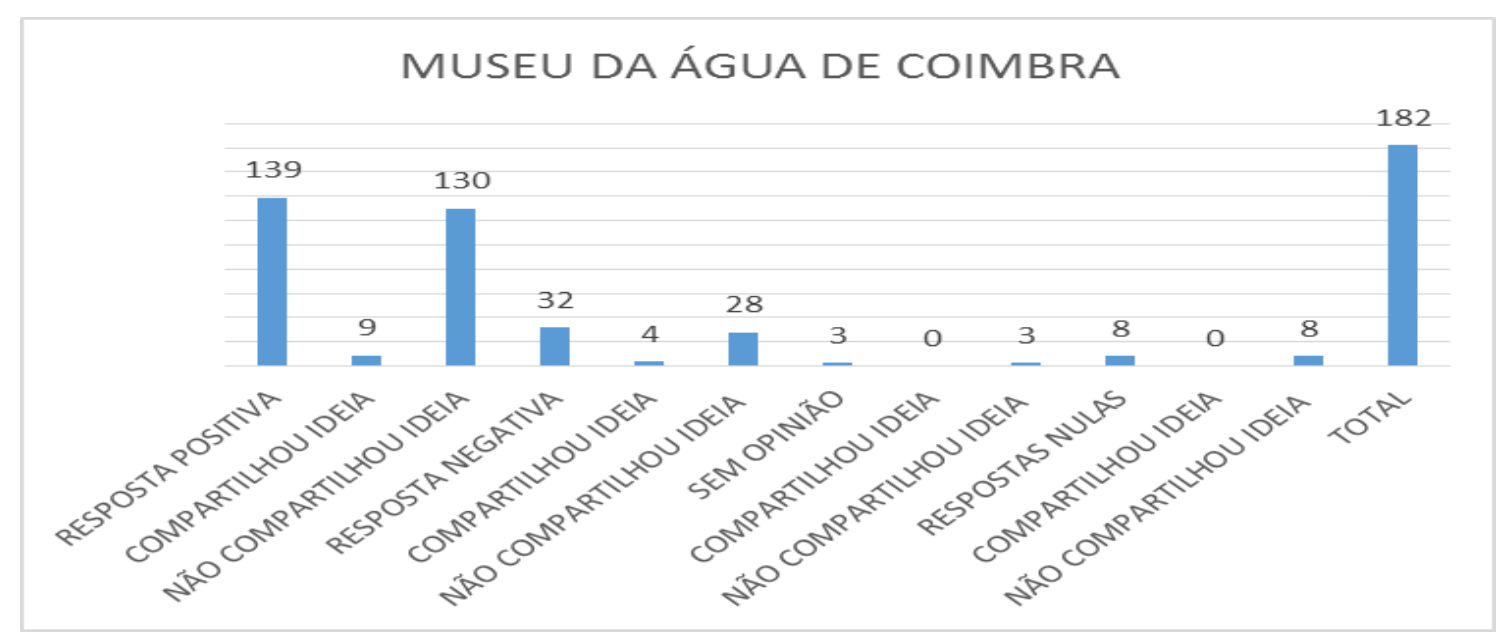

Fig. 6 - Gráfico referente à relação de respostas positivas e negativas, no Museu da Água de Coimbra (Oliveira, 2019, p. 69).

Os resultados do tratamento e análise de dados recolhidos nos dois museus indicam que poderão ocorrer diferenças entre instituições nos resultados que se referem à partilha de ideias. No entanto, dos resultados observados, é possível concluir que o Projeto Usina de Eureka é promissor pois, certifica números positivos ao fenómeno do visitante reconhecer que teve uma ideia durante a visita ao museu e se sentiu motivado a descrever a ideia para partilha. Mesmo no caso do MAC que apresentou resultados baixos quando comparado ao caso do $\mathrm{MMC}$, o fenómeno foi observado positivamente. 
Já na análise de dados que buscou respostas quanto ao reconhecimento de características ambientais que potencializam o processo cognitivo criativo, os números são categóricos. Em ambos os museus as respostas positivas apresentaram-se à frente das respostas negativas.

\subsection{2a fase}

Conforme referido, a definição do MN seguiu os parâmetros definidos na Tab. 1.

O MN Usina de Eureka considerou ser um facilitador para o desenvolvimento de novas ideias do público do museu. Segundo Anderson (2011), os momentos de descobertas devem ser mediados por facilitadores que possam direcionar o possuidor da ideia para o caminho do desenvolvimento da sua descoberta.

Ao reconhecer que os museus apresentam características que promovem o processo cognitivo criativo no indivíduo, é possível explorar tal particularidade e transformá-la num movimento inovador nestas instituições.

O modelo organizacional escolhido foi o cooperativista, que permite a prática de géneros diferenciados de serviços e associação de até vinte cooperados, que poderão servir-se da prestação de serviços da cooperativa e somar forças de interesse no desenvolvimento de ideias. As sinergias que poderão criar-se no âmbito da Cooperativa Usina de Eureka podem ser conferidas na Fig. 7.

O museu que acolher esta interface deverá fazer divulgação do serviço digital e, antes das visitas, deverá criar um plano de divulgação adequado às suas instalações e objetivos. Desta forma, a partilha de ideia deverá ser feita no módulo privado onde o visitante será remunerado com percentagem de rendimentos gerados pela comercialização de suas ideias e no segundo módulo, denominado de partilha aberta, os rendimentos advindos da prospeção da ideia serão revertidos para investimentos na cooperativa. 
É esperado que este formato de interface possa impulsionar o processo de inovação e colaborar com a sociedade da localidade em que a instituição está inserida.

Em linhas gerais os objetivos da Cooperativa Usina de Eureka são: (a) Desenvolver projetos a partir da ideia dos visitantes do museu. As realizações dos projetos oriundos das partilhas poderão ocorrer de forma conjunta com o seu idealizador ou, então, ele poderá deixá-la em uma espécie de repositório de realizações para que o desenvolvimento seja feito por terceiros, pelas equipas parceiras da interface Usina de Eureka; (b) Realizar reuniões com intervalos predefinidos para análise das ideias. Interessados em investir, comprar ou patrocinar o desenvolvimento dessas ideias poderão participar das reuniões e, assim, ter acesso à apresentação do repositório (Open Innovation); (c) Criar grupos de desenvolvimento e buscar, na comunidade local e zonas limítrofes, interessados em compor o grupo do projeto, respeitando as necessidades de competências; (d) Contribuir para o desenvolvimento económico do território e promover o emprego jovem; (e) Criar desafios de Eurekas com temáticas, para contribuir para o desenvolvimento local, integrado nos programas dos museus; (f) Incluir no roteiro uma visita às instalações da Usina de Eureka, onde serão elaborados discursos expositivos que contemplem os projetos desenvolvidos.

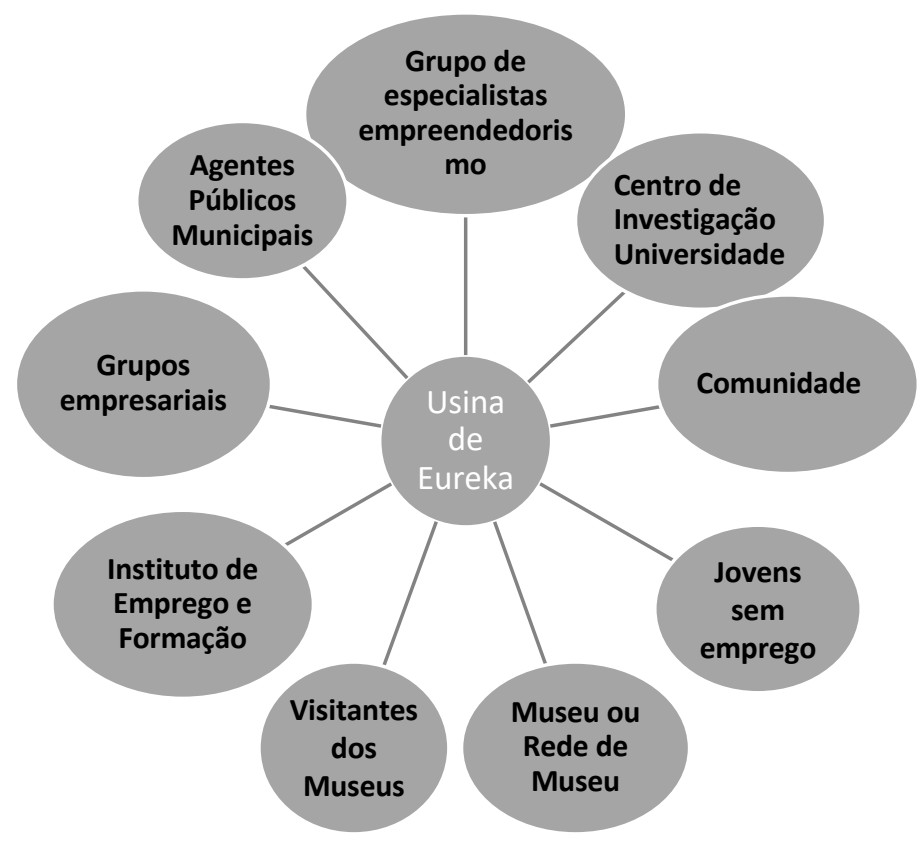


Fig. 7 - Possíveis sinergias que poderão compor a Cooperativa Usina de Eureka (Oliveira, 2019, p. 91).

\section{Considerações finais}

Os objetivos inicialmente definidos para o desenvolvimento deste projeto foram atingidos com sucesso.

A estruturação e definição dos métodos para elaboração do Projeto Usina de Eureka foram adequados e facilitaram o reconhecimento do potencial inovador das ideias que são geradas durante a visita a um museu e permitiram, também, pensar numa forma de agregar valor a esta "matéria-prima" gerada pelo público.

A recolha de dados e análise foram satisfatórias. No entanto, é de salientar que as amostras de dados recolhidos nos Estudos de Caso foram de pequena dimensão. Por este motivo, as análises apresentadas foram feitas apenas para ilustrar se o fenómeno de Geração de Ideia foi reconhecido nos visitantes dos museus estudados. No entanto, as análises e resultados deste estudo não são suficientes para considerar a generalização de resultados.

Quanto ao desenvolvimento de um MN, o trabalho mostrou a necessidade de integrar, no desenvolvimento da Usina de Eureka, as carências existentes no microambiente em que o museu está inserido, para oferecer um serviço que possa promover oportunidades que gerem resultados positivos para o desenvolvimento local, além das atribuições já praticadas pelos museus.

É esperado que este trabalho seja um contributo para que os museus possam compor, no seu dia a dia, ações para contribuir para o DS e ainda promover o desenvolvimento de novos estudos para impulsionar, cada vez mais, a relação do museu além dos seus muros. 


\section{Agradecimentos}

O desenvolvimento do projeto recebeu apoio do Museu Monográfico de Conimbriga e do Museu da Água de Coimbra, bem como a fundamental orientação e colaboração da Professora Doutora Maria Manuela Pinto e da Engenheira Alexandra Xavier (INEC TEC). Durante o percurso do Mestrado em Museologia a autora recebeu também o apoio da Professora Doutora Paula Menino Homem, Professora Doutora Carlota Simões e do Professor Doutor Pedro Casaleiro. Às Instituições e pessoas que colaboraram, a autora deixa aqui os seus sinceros agradecimentos.

\section{Referências}

- Agars, M. D., Kaufman, J. C., \& Locke, T. R. (2008). Social influence and creativity in organizations: a multi-level lens for theory, research, and practice. In M. D. Mumford, S. T. Hunter \& K. E. Bedell-Avers (Eds.), Multilevel Issues in Creativity and Innovation (Vol. 7, pp. 3-61). Oxford: Elsevier.

- Anderson, T. (2011). Beyond eureka moments: supporting the invisible work of creativity and innovation. IR Information Research, 16(1). Disponível em: http://informationr.net/ir/16-1/paper471.html

- Bailey, C. (Ed.) (2018). Museum And Creative Industries. Case Studies from Across Europe. Disponível em: https://www.nemo.org/fileadmin/Dateien/public/NEMO_documents/NEMO_2018_Publication _Museums_and_Creative_Industries_Case_Studies_from_across_Europe.pdf

- Bălan, M., \& Vasile, V. (2015). Cultural determinants of economic performance in Romania. Procedia - Social and Behavioral Sciences, 188, 290-296. https://doi.org/10.1016/j.sbspro.2015.03.396

- Bisadi, M., Mozaffar, F., \& Hosseini, S. (2012). Future research centers: the place of creativity and innovation. Procedia-Social and Behavioral Sciences, 68, 232-243. DOI: 10.1016/j.sbspro.2012.12.223 
- Borges, I. M. S. F. M. (2015). Criatividade nos Museus. Espaços entre e Elementos e Mediação. (Tese de Doutoramento, Universidade do Porto, Portugal). Disponível em: https://hdl.handle.net/10216/83987

- Chesbrough, H. W. (2003) The era of open innovation. MIT Sloan Management Review. 44(3), 35-41.

- Comissão Mundial sobre Meio Ambiente e Desenvolvimento (1991). Nosso futuro Comum. Rio de Janeiro: Fundação Getúlio Vargas. Disponível em: https://edisciplinas.usp.br/pluginfile.php/4245128/mod_resource/content/3/N osso\%20Futuro\%20Comum.pdf

- Direção-Geral do Património Cultural (2019). Estudo de Públicos de Museus Nacionais.

- Públicos do Museu Monográfico de Conímbriga - Museu Nacional. Lisboa. Disponível em: http://www.patrimoniocultural.gov.pt/pt/museus-emonumentos/dgpc/estudos-de-publicos

- Donley, F. (2014). Operating a Museum for Profit. Furthering the Dialogue About Corporate Structures Available to Museums. (Dissertação de Mestrado, Universidade de Washington, Estados Unidos da América). Disponível em: http://hdl.handle.net/1773/26496

- Eid, H. (2019). Museum and Innovation and Social Entrepreneurship. A New Model for a Challenging Era. London: Routledge.

- Eid, H. A. (2015). The Museum Innovation Model: A Museum Perspective on Open Innovation, Social Enterprise and Social Innovation. (Tese de Doutoramento, University of Leicester, Leicester). Disponível em: https://hdl.handle.net/2381/37502

- Falk, J., \& Sheppard, B. (2006). Thriving in the knowledge Age. New Business Model for Museums and other Cultural Institutions. Lanham: AltaMira Press.

- Fisher, J. (2018). Cultivating Creativity: Understanding Visitor Perceptions of Creativity in Art Museum Exhibits. (Dissertação de Mestrado, Universidade de 
Washington, Estados Unidos da América). Disponível em: http://hdl.handle.net/1773/42017

- Frimpong, A. A. (2017). Product Design by Recycling Aluminum in a Creative Learning Process in a Museum. (Dissertação de Mestrado, Universidade de Oslo e Akershus, Noruega). Disponível em: https://hdl.handle.net/10642/5098

- Gustafsson, C., \& Ijla, A. (2016). Museums: an incubator for sustainable social development and environmental protection. International Journal of Development and Sustainability, 5(9), 446-462.

- Hopwood, B., Mellor, M., \& O’Brien, G. (2005). Sustainable development: Mapping different approaches. Wiley Inter Science, 13, 38-52. DOI: $10.1002 / s d .244$.

- Jornal Notícias de Coimbra (2019). Museu da Água de Coimbra ultrapassou 112 mil visitantes. Versão eletrónica. Disponível em:

https://www.noticiasdecoimbra.pt/museu-da-agua-decoimbra-ultrapassou-os112-mil-visitantes/

- New INC (2019). Mission - NEW INC. New Museum. Disponível em: https://www.newinc.org/

- Nilsson, C. (2014). Innovation in Museums. Locating Key Changes Within the Elaborated Characteristics-based Model of Services. (Dissertação de Mestrado Universidade de Lund, Suécia). Disponível em: https://lup.lub.lu.se/studentpapers/search/publication/4689530

- Oliveira, M. R. A. E. (2019). Usina de Eureka. Museus como Impulsionadores da inovação. (Dissertação de Mestrado, Universidade do Porto, Portugal). Disponível em: https://hdl.handle.net/10216/124517

- República Portuguesa (2012). Programa Nacional de Coesão Territorial. Lisboa, Programas de Ação Governativa do Governo Constitucional. Disponível em: https://www.portugal.gov.pt/pt/gc21/governo/programa/programa-nacionalpara-a-coesao-territorial-/ficheiros-coesao-territorial/programa-nacional-paraa-coesao-territorial-pdf.aspx 
- Turoczy, R. (Cofounder). (2017). Startups \& Accelerators in Museums [Film]. Museum Next. Disponível em: https://www.museumnext.com/article/startupsaccelerators-museums/

- UNESCO Culture Sector (2018). Culture for the 2030 Agenda: Sustainable Development Goals. Disponível em:

https://unesdoc.unesco.org/ark:/48223/pf0000264687 


\section{Cláudia Garradas}

claudiagarradas@gmail.com

O Malta Study Center @ Hill Museum \& Manuscript Library: percurso e convergências. 
Garradas, C. (2021). O Malta Study Center @ Hill Museum \& Manuscript Library: percurso e

convergências. In P. M. Homem, B. Andrez, G. Soares, \& L. Amaral (Eds.), Ensaios e Práticas em

Museologia (Vol. 10, pp. 171-183). Porto: FLUP/DCTP/MMUS. https://doi.org./10.21747/978-989-

9082-06-9/102021a10

Resumo

Criado em 1973 com o intuito de preservar e divulgar a cultura material da Ordem de Malta, sede daquela ordem religiosa e militar durante mais de 200 anos, - Malta Study Center, parte integrante do Hill Museum \& Manuscript Library, tem, desde então, desenvolvido projetos de preservação e catalogação de manuscritos, livros raros e objetos de arte que ultrapassam as fronteiras da pequena ilha no seio do Mediterrâneo. O projeto inicial de microfilmagem de documentos raros e em risco, rapidamente se transformou num projeto sem termo e de alcance internacional. A entrada na era digital impulsionou a colaboração com diferentes profissionais e instituições locais para a criação de uma metodologia de catalogação e pontos de acesso, através do uso de normas, controlo de vocabulários e a criação de uma base de dados de autoridades.

Palavras-chave: Malta; Documentação; Normas; Controlo de vocabulário; Controlo de autoridade

\section{Nota biográfica}

Cláudia Garradas tem uma licenciatura em História, variante Arte (1998), e uma Pós-graduação em Museologia (2000) ambas pela Faculdade de Letras da Universidade do Porto (FLUP). Em 2008 concluiu o Mestrado em Estudos Artísticos, especialização em Estudos Museológicos e Curadoriais na Faculdade de Belas Artes da Universidade do Porto (FBAUP). Entre 1997 e 2013, exerceu funções no Museu da FBAUP, onde executou várias tarefas relacionadas com a gestão e catalogação das coleções, exposições e investigação. Desde 2016 que colabora com o Malta Study Center, parte integrante do Hill Museum \& Manuscript Library, onde desenvolve projetos de digitalização, catalogação e inventariação de arquivos e coleções públicas e privadas.

\section{Abstract}

Created in 1973 with the aim of preserving and disseminating the cultural material of the Order of Malta and the history of the island of Malta, ruled by that religious and military Order for over 200 years, the Malta Study Center at the Hill Museum \& Manuscript Library, has since developed projects of preservation and cataloguing of manuscripts, rare books and art objects that goes beyond the borders of this small island at the heart of the Mediterranean. The initially local microfilming project of rare documents at risk quickly became a project without term and with international visibility. The arrival of the digital imposed the need of a collaboration with different professionals and local institutions to create a methodology for cataloguing and finding aids, using standards, control of vocabulary and terminology and the creation of a database of authority files.

Keywords: Malta; Cataloguing; Standards; Controlled vocabulary; Authority files

\section{Biographical note}

Cláudia Garradas completed her bachelor's in Art History (1998), a two-year specialization in Museum Studies (2000), and her Master's degree in Museum and Curatorial Studies (2007), all at the University of Porto. She has a vast experience as a curator and collections manager acquired over the years she worked and was responsible for research, inventory, cataloguing, and documentation of collections and archival material at the Fine Arts Museum at University of Porto. As site director for the Malta Study Center (2016) she has been developing projects of digital preservation with public and private archives and museums, related with the Order of Malta and history of the island of Malta 


\section{Introdução}

Situado no meio do Mediterrâneo, com pouco mais de $300 \mathrm{~km}^{2}$ de área terrestre, o arquipélago de Malta (Malta, Gozo e Comino) é, desde os tempos fenícios, bastante apreciado pela sua localização geográfica, distando cerca de 90 km ao sul da Sicília, cerca de $280 \mathrm{~km}$ a nordeste da Tunísia e a cerca de $1510 \mathrm{~km}$ a oeste de Alexandria. Habitado desde o período do Neolítico, conforme certificam os vestígios arqueológicos dos templos em Ġgantija na ilha de Gozo e em Mnajdra no sul da ilha de Malta, o arquipélago maltês foi palco de uma expansão económica, social e cultural após a chegada da Ordem de São João de Jerusalém, de Rodes e de Malta, em 1530, que passou a chamar-se Ordem de Malta, sem precedentes na Europa. Malta foi governada por esta ordem religiosa e militar, criada no século XI com as Cruzadas, durante mais de dois séculos e meio, até à capitulação do último Grão-Mestre, aquando da invasão de Napoleão Bonaparte, em 1798, para dois anos depois se tornar uma Colónia Britânica, após a rendição do exército francês. A 21 de setembro de 1964 tornou-se independente do Reino Unido e constituiu-se como república em 1974 (Cassar, 2000).

Muito ou talvez ainda muito pouco se tenha escrito sobre o património cultural em Malta. Muito, porque muito já se escreveu sobre o legado artístico, arquitetónico, documental e percetual da Ordem de São João de Jerusalém, de Rodes e de Malta, ainda hoje tão presente em qualquer recanto da ilha. Muito pouco, porque as instituições que preservam este legado único, os museus, os arquivos e a Biblioteca Nacional, só agora começam a dar os primeiros passos na construção de uma base de trabalho comum. Estas instituições, em conjunto com o Malta Study Center (MSC) e o Department of Library Information, and Archive Sciences (LIAS) da Universidade de Malta, iniciaram recentemente um projeto de colaboração com vista ao uso de vocabulário controlado, terminologias e criação de controlo de autoridade, que permitirá a catalogação e inventariação sistematizada de coleções. Este projeto permitirá, não só a descoberta e construção de novas relações entre objetos e documentos, e consequentemente novas interpretações, como também uma maior 
divulgação de um património cultural único, ainda pouco conhecido além-fronteiras maltesas.

\section{A criação do Malta Study Center (MSC)}

O MSC, que se situa na Universidade e Mosteiro Beneditino de Saint John em Collegeville, Minnesota, foi criado em 1973 pelo maltês, Cônsul-geral em Minneapolis, Joseph S. Micallef. Fundou-o juntamente com Julian Plante, o então diretor executivo do Hill Museum and Manuscript Library (HMML), em que ficou integrado, consciente da devastação provocada pela Segunda Guerra Mundial e com o intuito de preservar a cultura material escrita da ilha de Malta (Anon., 2000-2001). Assim, orienta-se pela missão de

(...) to preserve and make accessible the hand-written and printed culture of Malta and the Sovereign Military Order of Saint John of Jerusalem, of Rhodes, and of Malta (also known as the Order of Malta) through digitization, research, and public engagement. (HMML, 2021b)

Depois do sucesso de um projeto-piloto com a Biblioteca Nacional de Malta (19711972), em agosto de 1973 dava-se início a um dos projetos mais importantes e longos, que ainda hoje se mantém ativo, entre o MSC e os arquivos e museus eclesiásticos de Malta. Inicialmente focado na microfilmagem de documentos históricos do período renascentista, o projeto depressa se alargou a outras fontes documentais, dada a sua importância e necessidade de preservação, pois o estado de conservação da maioria das coleções era bastante precário. Assim, nos anos subsequentes, foram microfilmados documentos relativos ao Tribunal da Inquisição e Santo Ofício em Malta, à Ordem de São João de Malta e registos musicais únicos de autores malteses e italianos. No fim do ano de 1999, o MSC tinha microfilmado, em Malta, mais de 22 mil fontes documentais datadas entre o seculo XI e o início do seculo XIX, relativas à Ordem de Malta e à história da ilha. 
Com os avanços tecnológicos e a implementação da Internet na década de 90, o HMML e, por conseguinte, o MSC, entrou numa fase de catalogação e documentação das coleções microfilmadas através de sistemas informáticos. É também nesta altura, que, um pouco por todo o mundo, se questiona (Hedstrom, 1993) a necessidade de criar, à semelhança das bibliotecas, catálogos eletrónicos para coleções de manuscritos e fontes documentais em arquivos. Várias foram as discussões levadas a cabo entre académicos, arquivistas e bibliotecários em torno da criação de normas para a catalogação de manuscritos. Alguns defendiam que a descrição normalizada de manuscritos podia limitar a descrição detalhada do conteúdo e características particulares do manuscrito, enquanto outros alertavam para o facto de este sistema poder incorrer em catalogações erróneas feitas por profissionais não qualificados. No que diz respeito ao HMML, o então novo diretor, Fr. Eric Hollas (HMML, 2021a), considerou que a catalogação eletrónica de manuscritos e arquivos era o caminho certo para a disponibilização e divulgação do trabalho desenvolvido pela instituição em vários países europeus, incluindo Portugal nos anos 80 com projetos desenvolvidos na Biblioteca Nacional, Museu de Arte Antiga e Museu Calouste Gulbenkian em Lisboa, bem como com a Biblioteca da Universidade de Coimbra, e alguns países africanos. 0 esforço desenvolvido por uma equipa liderada pelo espírito beneditino de preservação de diferentes saberes, no passado levado a cabo através da cópia de textos, impulsionou a criação de uma base de dados que viria a ser disponibilizada através do website da biblioteca do HMML. A primeira versão eletrónica do MSC foi disponibilizada online, no outono de 1995, na base de dados designada OLIVER.

A OLIVER foi construída com base no programa Microsoft Office Access e de um esquema desenvolvido pelo Electronic Access to Medieval Manuscripts (EAMMS) e, embora permitisse o acesso a todas as coleções do $\mathrm{HMML}$, foi essencialmente desenhada para manuscritos medievais tradicionais e não para material de arquivo. 0 desenvolvimento de uma base de dados online para material de arquivo teria de esperar até 2016, com o projeto Virtual HMML (vHMML). 


\section{A entrada na era digital}

Em 2003, o HMML inaugura um novo capítulo na sua história, o da era digital. O primeiro projeto digital do HMML acontece nesse mesmo ano no Iraque, aquando da guerra a fim de evitar a destruição total da cultura material escrita, então já sob a direção de Fr. Columba Stewart, monge Beneditino (HMML, 2021a). O reconhecido potencial da fotografia digital, que permite a obtenção de imagens a cores em alta resolução, um armazenamento reduzido, ao contrário dos microfilmes e, acima de tudo, uma relação de preço - qualidade, fez com que em 2007 o MSC, após o sucesso dos projetos levados a cabo pelo HMML, se iniciasse na era digital com um projeto nos Arquivos Nacionais em Malta. Desde então, ano após ano, foram-se alinhando vários projetos de digitalização (com vista à preservação, através da redução do uso regular de coleções em risco, quer pela falta de condições de acondicionamento, quer pela sua importância e consequente consulta pelos mais variados utilizadores) com instituições públicas e privadas, dentro e fora de Malta, mas sempre relacionados com a história da Ordem Religiosa e Militar e a sua estreita ligação com o arquipélago de Malta.

Em 2014, é nomeado o atual diretor do MSC, o Doutor Daniel K. Gullo (HMML, 2021a; 2021b), que introduz uma série de mudanças ao nível da catalogação, utilização de terminologias, controlo de autoridades e acesso virtual às coleções.

Atualmente, o MSC contabiliza mais de 16,000 rolos de microfilmes e 2,7 milhões de imagens digitais produzidas a partir de mais de 30,000 manuscritos, coleções de arquivo e livros antigos datados entre os séculos IX e XX, que se encontram disponíveis ao público através da nova plataforma digital $H M M L$ Reading Room ${ }^{1}$, criada em 2016 (HMML, s.d.b). Em 2018, foi adicionada a esta plataforma uma outra, dedicada a coleções museológicas.

\footnotetext{
${ }^{1}$ Base de dados criada através do software MySQL, com uma linguagem de programação JAVA, que utiliza o Digilib como servidor de imagens, a International Image Interoperability Framework (IIIF) para descrição e visualização de imagens digitais e o Elasticsearch para as pesquisas.
} 
A diversidade das coleções digitais e físicas que o HMML incorpora, incluindo as do MSC, exige diariamente um trabalho de coordenação de equipas multidisciplinares e internacionais, localizadas, quer nos países onde o HMML e o MSC têm projetos a decorrer, quer na sede em Collegeville, Minnesota. Este trabalho de coordenação inclui também a formação e consciencialização destas equipas para a importância do uso de vocabulários controlados e de listas de autoridades.

O uso de vocabulários controlados prende-se com a necessidade de promover e providenciar consistência e organização da informação, que é feita através do uso de termos definidos e do agrupamento de termos variantes e sinónimos. Os vocabulários controlados são essenciais não só para a organização da informação, como também para a construção de terminologias indispensáveis para catalogação e motores de pesquisa (Harping, 2016; Jorge, Medeiros, Alves, \& Medina, 2017). As listas de autoridades são também um tipo de vocabulário controlado, geralmente relacionadas com nomes de indivíduos ou organizações, se bem que, no caso do MSC, estas listas também incluem localizações geográficas e entidades institucionais.

A migração da informação da base de dados antiga, OLIVER, para a nova plataforma digital, o HMML virtual, em 2016, fez-se acompanhar de um trabalho intenso de atualização e de utilização das diferentes normas, nomeadamente a norma Describing Archives: A Content Standard (DACS), face à necessidade de uma norma que possibilitasse a catalogação e descrição de documentos manuscritos de forma estruturada, ao mesmo tempo que fornecia as ferramentas para a pesquisa desses registos, os seus agentes e as relações que se estabelecem entre eles; e a norma Descriptive Cataloguing of Rare Materials (Manuscripts) (DCRM-MSS) que, partindo da norma anterior, se configurou pela necessidade de uma norma para a descrição detalhada de materiais raros, existentes quer em livros quer em manuscritos.

Estas duas normas, ambas adotadas pela Sociedade Americana de Arquivistas, juntamente com a Encoded Archival Description (EAD) - a norma de codificação e estruturação padronizada dos vários instrumentos de catalogação e descrição através 
da linguagem XML - permitem, através da Library of Congress (a Biblioteca Nacional dos EUA), a criação de pontos de acesso cuja informação se encontra estruturada e organizada com base numa terminologia controlada. Ao mesmo tempo, deu-se início à criação de uma base de dados de controlo de autoridades para nomes, títulos, assuntos e tipologias. Com este trabalho, procurou-se e procura-se, porque é um trabalho contínuo, providenciar pontos de acesso online ao nível internacional para diferentes tipos de utilizadores, de diferentes partes do mundo e, por conseguinte, diferentes idiomas, cada vez mais exigentes no que diz respeito ao acesso à informação e imagens de alta qualidade.

\section{Catalogação, terminologias e a criação de uma base de dados de} autoridades

No processo de tratamento de informação relativa a coleções museológicas e não museológicas, é da máxima importância o uso de normas e o controlo de vocabulários e terminologias, de forma a garantir pontos de acesso normalizados. Esta tarefa, tem sido, no entanto, mais desenvolvida ao nível das bibliotecas e arquivos do que em museus. Os referidos pontos de acesso normalizados só são possíveis através do controlo de autoridades, de forma a evitar disparidades, naturalmente criadas por homónimos, sinónimos, variantes de nomes e diferenças linguísticas. Neste âmbito, salienta-se o trabalho desenvolvido pelo Virtual International Authority File (VIAF), um consórcio de cooperação entre bibliotecas e agências nacionais, estabelecido em 2003 e coordenado pelo Online Computer Library Center (OCLC), com o intuito de criar e disponibilizar registos internacionais, normalizados, de autoridades.

As autoridades disponibilizadas pelo VIAF são estabelecidas por meio da unificação de dados estruturados, utilizados na descrição das autoridades realizadas por cada biblioteca nacional ou instituição cooperante, respeitando as diferenças linguísticas e culturais das mesmas. O objetivo principal do VIAF é disponibilizar informação precisa, 
consistente e o mais completa possível ao nível internacional. Para que isto seja possível, as bibliotecas e as agências cooperantes fazem uso de normas e vocabulários controlados.

No que diz respeito ao trabalho desenvolvido pelo MSC, importa lembrar que o centro desenvolve projetos relacionados com a Ordem de Malta e a história da ilha, e que, salvo algumas exceções, as autoridades relacionadas com a Ordem ou com Malta são praticamente inexistentes ou estão registadas incorretamente. Por esta razão, e especialmente porque, nos últimos dois anos, o MSC levou a cabo uma intensa e sistemática campanha de catalogação das suas coleções digitais, que resultam dos projetos de digitalização que desenvolveu, surgiu a necessidade de criar um conjunto completo de registos de autoridades que incluísse indivíduos, organizações, lugares e famílias. Paralelamente, a continuação do desenvolvimento de novos projetos, incluindo a digitalização de coleções museológicas, sobretudo desenhos, gravuras e mapas, revelou ser da máxima importância o estabelecimento de uma metodologia específica para Malta. Esta metodologia, criada em colaboração com as instituições locais, museus, Biblioteca Nacional, Arquivo Nacional e Universidade, incorpora as normas internacionais usadas pelo MSC e aprovadas ao nível nacional - DACS, para manuscritos e Resource Description and Access (RDA) para listas de autoridades - e tem como principal objetivo permitir a todas as instituições que incorporam vestígios da cultura material e escrita relativa à Ordem de Malta, identificar, catalogar e tornar acessível uma variedade impressionante de documentos, livros raros e obras de arte de forma sistematizada e uniforme.

A recente atribuição de uma bolsa (National Endowment) na área das Humanidades, permitiu ao HMML e, por conseguinte, ao MSC, a oportunidade de criar uma base de dados de autoridades dedicada às Tradições Cristãs e Islâmicas e, no caso do centro, o primeiro arquivo de autoridades inteiramente dedicado aos registos da Ordem religiosa e militar e da ilha de Malta (HMML, 2021c). A base de dados está em fase de testes e, por isso, ainda não se encontra disponível para consulta pública. A criação desta base de dados, HMML Authority File (HAF), cuja informação é submetida para 
autorização ao Library of Congress's Name Authority Cooperative Program (NACO) e feita em estreita colaboração com o Program for Cooperative Cataloging, do qual o HMML é parceiro, tem como principal objetivo disponibilizar uma série de registos, cuja especificidade até ao momento não tinha permitido criar, fazendo o uso de normas e de terminologias, quer para arquivos quer para coleções museológicas.

Em 2018, o HMML criou a sua mais recente plataforma dedicada a coleções museológicas, o vHMML Museum (HMML, s.d.a), que foi disponibilizado ao público em maio de 2019. Nesta nova plataforma do HMML virtual, os utilizadores têm acesso a gravuras, desenhos, objetos de cerâmica, fotografias e slides das coleções do HMML do Ocidente, Oriente Médio, África e Leste Asiático, à coleção Arca Artium, doada em 1995, mas também a todas as coleções que o MSC digitalizou em Malta, nomeadamente, as coleções de desenhos, gravuras, mapas e manuscritos raros, do MUŻA - National Museum of Fine Arts (Mużew Nazzjonali tal-Arti) em Valletta, do Malta Maritime Museum, em Birgu e, mais recentemente, a coleção de desenhos antigos do Cathedral Museum, em Mdina.

O trabalho desenvolvido ao nível da catalogação e descrição de manuscritos, com normas adotadas, controlo de vocabulário e terminologias, foi exatamente o mesmo aplicado às coleções de arte. Com base na consulta do manual Categories for the Description of Works of Art (CDWA) (Baca \& Harpring, 2019), feito com base num extenso trabalho de mapeamento com outras normas, como por exemplo MARC, EAD, DACS, entre outras, o MSC criou um conjunto de vocabulário que respeita as normas internacionais, mas que é, ao mesmo tempo, aplicado a um contexto muito particular; o da ilha de Malta e sua estreita relação com a Ordem.

Desta forma, e com a criação da nova base de dados de registos de autoridades, manuscritos, documentos raros impressos e coleções de arte de qualquer parte de mundo, que estejam ligados à história da Ordem de Malta, podem relacionar-se entre si através de um nome, seja de uma pessoa, de um país, de uma instituição, ou de uma 
tradição, permitindo ao utilizador um acesso normalizado e estruturado de um conjunto único e completo de informação.

\section{Considerações finais}

O trabalho desenvolvido ao longo dos últimos 50 anos pelo MSC, parte do $\mathrm{HMML}$, é notável e de uma dimensão que vai para além das fronteiras do pequeno arquipélago da República de Malta. Primeiro, ao nível da preservação de coleções em risco, quer devido ao seu estado de conservação, quer por serem pouco ou nada conhecidas e poderem, assim, ser esquecidas; segundo, pela criação de um sistema de inventariação e de catalogação de fundos documentais e de coleções de arte especificas de um contexto geográfico e histórico muito particular, o da ilha de Malta e da Ordem de Malta, respeitando as normas internacionais.

A criação deste sistema, que se impõe como uma metodologia a ser adotada, permite que objetos de diferentes coleções, de diferentes tipologias, que se encontram em países diferentes, se relacionem entre si, proporcionando o acesso e o estudo de coleções hoje dispersas, mas que outrora estiveram fisicamente unidas. Esta metodologia irá igualmente permitir a reconstrução de arquivos e coleções fragmentadas, possibilitando novas leituras e, potencialmente, uma nova interpretação da estrutura da Ordem de Malta e da relação entre o Convento, sediado na ilha de Malta, e as suas periferias, como por exemplo, Portugal.

Este trabalho reflete o esforço conjunto de arquivistas, bibliotecários, museólogos e especialistas na área das novas tecnologias cujo objetivo principal é a criação de metodologias de catalogação e inventariação para arquivos, bibliotecas e museus, que respeitam a diferença das coleções, os seus sistemas de tratamento de informação e a própria diferença genética das instituições, mas que ao mesmo tempo as unificam, com o intuito de providenciar aos utilizadores um acesso sistemático e uniformizado. 
Se as novas tecnologias vieram impulsionar a cooperação entre profissionais e instituições, com a vista à construção de uma base de trabalho e linguagem comuns, o aumento de informação digital disponibilizada pelos arquivos, bibliotecas e museus impulsionou a necessidade de otimizar os pontos de acesso, de forma a responder às variadíssimas necessidades dos, também eles diferentes, utilizadores.

É neste sentido, e com o principal objetivo de divulgar a cultura material da Ordem de Malta e a história da ilha, que o MSC tem unido esforços com os profissionais e instituições locais, Universidade, Arquivo Nacional, Biblioteca Nacional, arquivos eclesiásticos e museus, para a criação de uma metodologia e acesso internacional normalizado, que começa a dar frutos e a receber a atenção internacional que merece.

\section{Agradecimentos}

A autora agradece ao Doutor Daniel Gullo, Diretor do MSC, pelo apoio e à Doutora Valeria Vanesio, pelo constante incentivo e informação disponibilizada.

\section{Referências}

- Anon. (2000-2001). The Malta Study Center: An overview. Melitensia (Fall and Winter 2000-2001). Disponível em: https://hmml.org/assets/pdf/2000Melitensia-Fall.pdf

- Baca, M., \& Harpring, P. (Eds.) (2019). Categories for the Description of Works of Art (CDWA). List of Categories and Definitions. J. Paul Getty Trust \& College Art Association, Inc. Disponível em: https://getty.edu/research/publications/electronic_publications/cdwa/definiti ons.pdf

- Cassar, C. (2000). A Concise History of Malta. Msida: Mireva Publications. 
- Harpring, P. (2016). Introdução aos Vocabulários Controlados: Terminologia para Arte, Arquitetura e Outras Obras Culturais. São Paulo: Secretaria da Cultura do Estado de São Paulo; Pinacoteca de São Paulo; ACAM Portinari. Disponível em: https://issuu.com/sisem-sp/docs/vocabul_rios_controlados__digital

- Hedstrom, M. 1993. Descriptive practices for electronic records: Deciding what is essential and imagining what is possible. Archivaria, 36 (January). https://archivaria.ca/index.php/archivaria/article/view/11934.

- HMML (2021a). History. A singular mission for more than 55 years. Preserving and sharing the world's handwritten past to inspire a deeper understanding of our present and future. Disponível em: https://hmml.org/about/history/

- HMML (2021b). Malta Study Center. Disponível em: https://hmml.org/research/msc/

- HMML (2021c). Resources for the Description of Manuscripts from Understudied Christian and Islamic Traditions. Disponível em: https://hmml.org/research/resources-for-access-authority/

- HMML (s.d.a). Museum. HMML Museum. Disponível em: https://www.vhmml.org/museum

- HMML (s.d.b). Reading Room. HMML Reading Room provides access to thousands of items in HMML's collections. Disponível em: https://www.vhmml.org/readingRoom/

- Jorge, N., Medeiros, F., Alves, J. R., \& Medina, S. (2017). Os vocabulários controlados na organização e gestão de informação sobre património cultural: orientações práticas. Zenodo. https://doi.org/10.5281/zenodo.3979204 


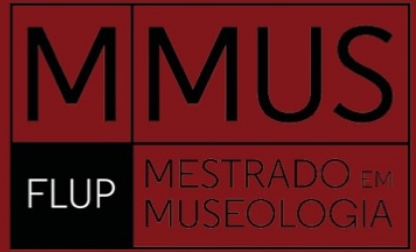

\section{ENSAIOS E PRÁTICAS EM MUSEOLOGIA 10}

\section{Respeita o Acordo Ortográfico da Língua Portuguesa}

(De 1990, aprovado pela Resolução da Assembleia da República n.o 26/91, de 23 de agosto, e ratificado pelo Decreto do Presidente da República n.o 43/91, de 23 de agosto)

\section{Procura incorporar as Web Content Accessibility Guidelines}

(WCAG 2.0)

\section{É protegida pela Licença Internacional}

Creative Commons Atribuição-NãoComercial-Compartilhalgual 4.0

(Detalhes da licença: creativecommons.org/licenses/by-nc-sa/4.0/)

\section{(1) (1) (2)}

Attribution-NonCommercial-ShareAlike 4.0 International License (CC BY-NC-SA 4.0) 